\title{
JULIANE BUCHINSKI
}

\section{INSTRUMENTS TO CHALLENGE THE GRANT OF A PATENT AS A THIRD PARTY}

SUGGESTIONS FOR THE REVIEW OF NEW ZEALAND'S PATENT SYSTEM

\section{LL.M DISSERTATION (LAWS 592)}

\section{FACULTY OF LAW}

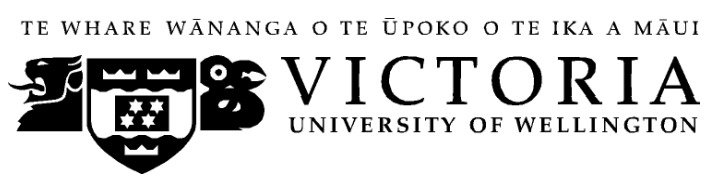




\section{JULIANE BUCHINSKI}

INSTRUMENTS TO CHALLENGE THE GRANT OF A PATENT AS A THIRD PARTY

$-$

SUGGESTIONS FOR THE REVIEW OF NEW ZEALAND'S PATENT SYSTEM

Table of Contents

Abstract

Word length

\section{INTRODUCTION}

II A PATENT SYSTEM - HOW DOES IT WORK?

A What is a Patent?

B Justification of a Monopoly

C Economic Impact of a Patent System

1 Incentive for innovation

2 Incentive for disclosure

3 Intermediate result

4 How does the economic impact of patents influence the review process in New Zealand?

D Keeping the Balance

E Is the New Zealand Patent System in Balance?

F How Could the New Zealand Patent System Be Balanced?

III ENHANCING THE QUALITY OF PATENTS

A What Is Meant by Patent Quality?

B How Can the Quality of a Patent Be Enhanced?

1 Patent Office or Courts - Who would be the best to eliminate "bad" patents?

$2 \quad$ Patent Office

3 Courts

4 Intermediate result

IV ENHANCING THE QUALITY OF PATENTS BY THIRD PARTIES

A Involving the General Public In Order to Enhance the Quality of Patents

1 Giving third parties influence

2 Practicability of third party influence

$3 \quad$ Third party influence as a solution for New Zealand

B What Instruments Does a Third Party Have to Influence the Grant of a Patent?

1 Submission of information by a third party before the patent is granted

2 Re-examination

3 Opposition

$4 \quad$ Challenging the validity of patents before the Courts

C What Types of Review Systems Are Available?

1 Inquisitorial review systems

2 Adversarial review system

3 Hybrid review system

V SYSTEMS IN BALANCE - INTERMEDIATE RESULT

VI NEW ZEALAND'S PATENT SYSTEM AT WORK

A Scope of the Patent System in New Zealand

$1 \quad$ Patent policy in New Zealand

2 Influences from the outside on New Zealand's patent policy

3 Particular issues for New Zealand 
B Objections Against the Current New Zealand Examination Procedure by the IPONZ

$1 \quad$ Resources of the IPONZ

$2 \quad$ Automatic examination

3 Standard of examination

$4 \quad$ No automatic publication

C Objections to the Current New Zealand Patent Review System: Third Party Instruments According to the Patents Act 1953

1 An hybrid approach

2 Influence of third parties in terms of quantity

$3 \quad$ Influence of third parties in terms of quality

$4 \quad$ Advantages and disadvantages of this system

D Intermediate Result

VII REFORM PROCESS IN NEW ZEALAND

A History of Reform

1 Government reports with respect to patent law

2 Draft Patents Bill 2004

$3 \quad$ Patents Bill 2008

B Proposed Amendments of the Patents Bill 2008

$1 \quad$ Higher standard of examination

2 Third-party instruments according to the Patents Bill 2008

C Are the Amendments of the Patents Bill 2008 an Appropriate Solution for New Zealand?

1 Changes in the standards of examination

2 New third-party instruments

VIII SUGGESTED ROUTE FORWARD FOR NEW ZEALAND
A Developing a New Approach for the New Zealand Review System
B Framework of a New Approach
1 International framework for a patent reviewing system
$2 \quad$ Harmonisation with important trade partners
C The New Approach - Third-Party Instruments for New Zealand
1 Assertion by any third party after publication of the specification on all questions of patentability
$2 \quad$ Pre-grant opposition on the grounds of novelty and obviousness
3 Revocation before the Commissioner and the Court without limited
grounds
IX CONCLUSION
BIBLIOGRAPHY 


\section{Abstract}

In recent decades, intellectual property law (in particular patent law) has had to face new challenges due to the accelerating development of technology. Patents can have a negative effect on a country's economy if too many invalid or overly broad patents are granted. Such patents have the potential to impose high costs on society without providing substantial benefits. If a patent regime cannot avoid the grant of such patents, or does not provide instruments to remove them from the register, the negative effect may stifle innovation instead of encouraging it. In 2008, in consideration of these problems, the government of New Zealand introduced a Patents Bill. This Bill is the culmination of the government's review process, which started in the late 1980s. The aim of the Bill is to update New Zealand's patent law in order to bring it in line with international practise and to reduce the costs to society arising from invalid and overly broad patents. The provisions of the Bill cover all principal aspects of the patent regime: standards of examination and procedures, challenges on the grant of a patent, and provisions for updating the regulatory regime for patent attorneys. This dissertation focuses on analysing how the quality of New Zealand's patents could be enhanced using the knowledge and experience of third parties. Because the current examination standards may allow the grant of overly broad patents, this dissertation analyses specifically which changes in the examination procedure could help prevent the grant of "bad" patents without overburdening the resources of the IPONZ. In the next step, the dissertation analyses third-party instruments under the current patent system and under the Patents Bill 2008, proving that neither approach by itself would be sufficient to bring about an effective patent reviewing system for New Zealand. The approach under the current system is too expensive and has the potential to delay the granting procedure, whereas the approach proposed by the Patents Bill 2008 limits the influence of third parties before the grant of a patent to such an extent that most patents may remain in the register. The overall aim of this dissertation is to suggest a new approach that includes aspects of both of the others in order to find a balanced solution and an optimal fit for the specific needs of New Zealand. 


\section{Word length}

The text of this paper (excluding abstract, table of contents, footnotes, and bibliography) comprises approximately 32,700 words. 
I INTRODUCTION

Over recent decades, the importance of intellectual property rights in general and patents in particular has steadily increased. After a long dormancy, patent law has of late attracted remarkable attention from the judiciary, the legislature, and the executive branch of government. In the past few years in particular, the development of new technologies has placed great pressure on patent law to provide effective protection, since increasing numbers of patents have been granted outside the traditional fields. ${ }^{1}$ As a result, traditional intellectual property protection has undergone wide-reaching changes worldwide. Most countries in the world have confronted these new challenges and adapted their laws accordingly, reasoning that, as Mark Twain once famously said, "a country without a patent office and good patent laws was just a crab and couldn't travel anyway but sideways and backwards" ${ }^{2}{ }^{3}$

What is the situation in New Zealand? The current New Zealand patent regime is exceptionally in comparison to other national patent systems in several ways. The patent law of New Zealand is governed by the New Zealand Patents Act 1953, which, although it has been amended on several occasions, ${ }^{4}$ has remained unchanged in most of its fundamental

For example, John R Thomas stated: "With industry routinely seeking patent protection for gene sequences, software, business methods, and other postindustrial inventions, numbers of stakeholders have freely expanded in recent years.", see Thomas "Collusion and Collective Action in the Patent System: A proposal for Patent Bounties" (2001) U Ill L Rev $305,316$.

$2 \quad$ USPTO "Mark Twain Granted His First Patent on December 19, 1871 Famous author and humorist was also an inventor" (18 December 2001) Press Release.

3 For example, with regard to the most important patent regimes, the last significant review of the European patent regime was in 2000, see Convention on the Grant of European Patents (European Patent Convention), (5 October 1973) 1065 UNTS 199 (as revised by the Act revising the EPC of 29 November 2000) [EPC]; the last review of the Japanese patent regime was in 2008, see Japanese Patent Act (Act No. 121 of 1959) (through the revision of Act No 16 of 2008) [Japanese Patent Act] and the last significant review of the United State patent regime was in 2007, see United States Patents Act 35 USC (Part I - Patent and Trademark Office, Part II - Patentability of Inventions and Grant of Patents, Part III Patents and Protection of Patent Rights, Part IV - Patent Cooperation Treaty; as amended in September 2007) [35 USC].

$4 \quad$ Patents Amendment Act (No 91) 1972; Patents Amendment Act (No 112) 1976; Patents Amendment Act (No 81) 1992; Patents Amendment Act (No 122) 1994; Patents Amendment Act (No 139) 1996; Patents Amendment Act (No 119) 1999 and Patents Amendment Act (No 72) 2002. Furthermore, there has been other legislation repealing and 
principles since its original enforcement in $1955 .{ }^{5}$ As a result, New Zealand patent law still includes some regulations that were updated long ago in other patent regimes. ${ }^{6}$ For example, in most jurisdictions worldwide, prior art (the base for novelty) is geographically unlimited, but New Zealand patent law still has a local novelty concept. ${ }^{7}$ New Zealand is one of the last countries in the world where foreign prior art cannot be used in determining the novelty of an invention. ${ }^{8}$ This means that it would be theoretically possible to obtain a patent in New Zealand for an invention already known in other countries. A further characteristic of New Zealand's patent regime is that the patent office will not examine applications for obviousness unless a third party challenges the patent application in an opposition or revocation procedure. ${ }^{9}$ Thus, an applicant may obtain a monopoly for an invention that lacks the inventive step. These are only a few of the particularities of the New Zealand patent system that distinguish it from other national patent systems. ${ }^{10}$

Consequently, it has been said that "New Zealand does not have an up-to-date Patent Act which is thought to be peculiarly appropriate to New

implementing sections of the Patents Act 1953, including the Lawyers and Conveyancers Act (No 1) 2006.

The only significant amendments of New Zealand's intellectual property legislation have been made in order to fulfil international treaty obligations. For example, with regard to the Patent Cooperation Treaty (9 June 1970) 1160 UNTS 231 [PCT], see Patents Amendments Act 1992 No 81; regarding the Trade-Related Intellectual Property Rights Agreement of the Uruguay Round (15 April 1994) 1869 UNTS 299; (1994) 33 ILM 81 [TRIPS], see Patents Amendment Act (No 122) 1994; see generally Ministry of Economic Development "Reform of the Patents Act 1953" www.med.govt.nz (last accessed 10 November 2009). For example, the New Zealand Patents Act 1953 is a substantial re-enactment of the 1949 United Kingdom Patents Act, which the United Kingdom completely reviewed in 1977 to comply with European obligations and international conventions, see W R Cornish Intellectual Property: Patents, Copyright, Trade Marks and Allied Rights (3rd ed, Sweet \& Maxwell, London, 1996) para 3-01.

$7 \quad$ Patents Act 1953, s 2(1).

$8 \quad$ Graham Dutfield and Uma Suthersanen Global Intellectual Property Law (Edgar Elgar Publishing, Cheltenham, 2008) 120.

9 The Examiner only searches for prior publication and prior claiming in order to examine the application for novelty, Patents Act 1953, ss 13, 14.

A good overview of patent law in New Zealand is provided by Ian Finch (ed) James \& Wells Intellectual Property Law in New Zealand (Thomson Brookers, Wellington, 2007); Susy Frankel and Geoff McLay Intellectual Property in New Zealand (LexisNexis Butterworths, Wellington, 2002) and Andrew Brown and Anthony Grant The Law of Intellectual Property in New Zealand (Butterworth, Wellington, 1989). 
Zealand's particular needs and expectations." of patents is less strict than in other countries, with the result that patents are far too easily obtained in New Zealand. ${ }^{12}$ Furthermore, New Zealand's patent law is outdated and differs too much from the laws of most other industrialised countries, counter to the international ambitions of patent law harmonisation. The government, legal scholars, and the representatives of commerce and business are in almost unanimous agreement that the New Zealand Patent Act 1953 is overdue for reform.

There is a broad consensus that an update of New Zealand patent law should aim to bring it into line with the laws of its important trading partners. In addition, it should seek to promote local inventions as well as to encourage international companies to import technology and to invest in New Zealand. ${ }^{13}$ The reform should help ensure that New Zealand gains the greatest value for its innovations, particularly considering that over 90 per cent of New Zealand's patents are granted to non-residents. ${ }^{14}$

Nevertheless, the question as to how the patent law should be revised in order to meet New Zealand's needs is still subject to long debates. ${ }^{15}$ The beginning of the reform process in New Zealand dates back to the mid1980s. Since then, several different official institutions have issued reports on the reform of New Zealand's intellectual property system. ${ }^{16}$ In 2004, the

See quote of Hammond $\mathrm{J}$ in Pfizer Inc $v$ Commissioner of Patents [2005] 1 NZLR 362, para 102, (CA) Hammond J [Pfizer].

See speeches in the first reading of the Patents Bill 2008, (5 May 2009) 654 NZPD 2883 [first reading].

Ministry of Commerce Reform to the Patents Act 1953: Proposed Recommendations (Wellington, 1992) 3 [Proposed Recommendations].

In 2001, for example, 4727 patents were granted in total: 376 to residents and 4351 to nonresidents, see Ministry of Economic Development Review of the Patents Act 1953: Boundaries to Patentability - A Discussion Paper (Wellington, 2002) 6 [Boundaries to Patentability].

See first reading, above $\mathrm{n} 12$.

For example, Industrial Property Advisory Committee The Patent Monopoly Term and Extensions Thereof (IPAC, Wellington, 1985); Industrial Property Advisory Committee The Adequacy of Definition and Disclosure in Patent Specifications Relating to MicroOrganism Inventions (IPAC, Wellington, 1987), New Zealand Law Commission Intellectual Property: The Context for Reform (NZLC R13, Wellington, 1990) 13 [The Context for Reform]; Competition Policy and Business Law Division Review of Industrial Property Rights Patents, Trade Marks and Design: Possible Options for Reform (Ministry of Commerce, Wellington, 1990) Vol 1 and 2 [Possible Options for Reform]; Proposed Recommendations, above n 13; Ministry of Commerce Maori and the Patenting of Lifeform 
Ministry of Economic Development released a first draft of a Patents Bill for consultation by professionals. ${ }^{17}$ It took another four years before the Bill was introduced in the Parliament. ${ }^{18}$ The Patents Bill 2008 is an important step in the revision process of New Zealand's patent law. The most important changes include a higher proposed standard of examination by introducing the absolute novelty standard, the examination for obviousness and usefulness, and a revised definition of a patentable innovation that includes explicit exclusions from patentability. It changes the instruments for third parties to challenge the grant of a patent by abolition of the pregrant opposition and its replacement by re-examination. ${ }^{19}$ Furthermore, the Bill proposes the establishment of a Maori Advisory Committee to provide advice to the Commissioner of Patents on applications for inventions involving indigenous plants and animals. ${ }^{20}$ At present, the Bill is still in the parliamentary process: its first reading was in the beginning of 2009 and, with the submission term now ended, the Bill is currently pending before the Commerce Committee.

While the introduction of the Patents Bill 2008 was welcomed as a first step in the right direction, most of the proposed changes are still controversial. The government has acknowledged the implications of some critical policy issues of the Bill and has tasked the Commerce Committee with clarification of these matters. ${ }^{21}$ A report of the Commerce Committee was due in March 2010.

However, as addressing every critical question regarding the New Zealand patent system is beyond the possible scope of a dissertation, this dissertation is limited to one of these issues: the changes regarding the influence of a third party in the patent granting procedure in New Zealand patent law.

Inventions An Information Paper Produced by the Patenting Lifeforms Focus Group for the Ministry of Commerce (Wellington, 1999); Boundaries to Patentability, above n 14. Ministry of Economic Development Draft for Consultation Patents Bill 2004 (Wellington, 2004) [Draft Bill]. Patents Bill 2008, no 235-1. [Patents Bill 2008]. Ibid, cls 88-90. Ibid, cl 276. Ministry of Economic Development Submissions on Exposure Draft of Patents Bill (Wellington, 2005) 
While the Patents Act 1953 provides third parties with the instrument of pre-grant opposition and allows an early and strong influence on the granting procedure ${ }^{22}$, the Patents Bill 2008 significantly shifts this system, replacing pre-grant opposition with a re-examination procedure. ${ }^{23}$ This development towards a system that gives third parties weaker and later influence in the granting process has been highly controversial and has been criticised on several grounds. In particular, emphasis has been placed upon the fact that an opponent to a grant is vulnerable to infringement actions after the grant of a patent, because a patent can be already enforced during the opposition procedures. ${ }^{24}$ On the other hand, one of the main reasons to replace the current pre-grant opposition with a re-examination procedure is that this will provide a simpler and cheaper way of challenging the grant of a patent. $^{25}$

The goal of this dissertation is to show that, for New Zealand, a new approach with stronger and earlier third party influence could be more efficient and therefore may better fulfil the particular needs of this country. In order to prove this thesis, the dissertation will start with a theoretical analysis of why third parties should have an influence on the granting process at all, with reference to the purpose of patents. It will explain how the influence of third parties can help strengthen patents, insuring that patents will be granted only to true inventions. The different instruments for third parties provided by patent regimes worldwide will be analysed, identifying their respective benefits. Thereafter, the dissertation will examine the current situation in New Zealand, demonstrating that under the existing intellectual property system, patents are too easily obtained and that invalid patents may survive in the market. In addition, this dissertation will analyse the current system and the proposed Patents Bill with regard to particular issues, such as New Zealand's role as a small economy and net

Patents Act 1953, s 21.

Patents Bill 2008, cls 88-90.

Opinion from Patent Law Firm A J Parks, see first reading, above n 12, 2902.

Patents Bill 2008 (Explanatory Note), 54. 
importer of technology, ${ }^{26}$ the harmonisation with important trading partners $^{27}$, and the concerns of the Māori. In its conclusion, this dissertation will reveal that even though most of the changes provided by the Patents Bill 2008 will improve the quality of patents, the changes regarding the influence of third parties have the potential to impede this progress. Moreover, it will show that with respect to issues specific to New Zealand, a different approach regarding third party influence might be more beneficial. Finally, this dissertation will aim to develop an alternative approach to the structure of patent law in New Zealand with respect to the instruments for a third party, in order to better fulfil the needs of the country and to support the reforms that a modern patent system requires.

It is clear that changing third-party instruments will affect developments in other areas of the New Zealand patent system. However, addressing these or subsequent questions cannot be part of the framework for this particular dissertation. ${ }^{28}$ Nevertheless, a discussion about the influences arising from third parties in the granting procedure is a good starting point to encourage debate over which patent system would be the best fit for New Zealand.

After a brief introduction on patent theory in Part II, this dissertation will give a background on patents and reasons for granting them. Part III will briefly summarise why the quality of patents is so important and how the influence of third parties could help to improve it. Part IV will then give an overview on how the influence of third parties can be structured and which instruments already exist in patent systems worldwide. Part V will summarize the theoretical elements of this dissertation. Part VI will present an overview of the objections to the current examination standards and the

The term "net importer for technology" expresses that New Zealand imports more technology than it exports. This term is widely used by the New Zealand Government; see Boundaries to Patentability, above n 14.

For example, international agreements such as TRIPS, see above $\mathrm{n} 5$; or bilateral agreements with important trade partners such as Australia (ANCERTA, TTMRA or Memorandum of Understanding on Business Law Harmonisation), see in detail below Part VIII B. 2(a).

For example, this dissertation cannot include subsequent debates on topics such as what would be the best equipment for the Patent Office. These questions will need to be answered in future analyses. 
current third-party instruments in New Zealand's patent law. Part VII will examine the proposed amendments of Patents Bill 2008 with respect to the particular needs of New Zealand. This section will also consider the proposed shifting of third-party influence by critically analysing the impacts of the changes as planned. The conclusion will demonstrate that both the current system and the proposed reforms have advantages and disadvantages. However, some of the proposed changes, particularly the abolition of pre-grant opposition in favour of a re-examination scheme, may not provide the desired benefits. Therefore, Part VIII will provide an alternative approach designed with the particular needs of this country in mind. Finally, Part IX will conclude whether this new approach is the best solution for the country's needs and explain why it would be appropriate to rethink the design of third-party instruments in the New Zealand patent regime.

\section{A PATENT SYSTEM - HOW DOES IT WORK?}

In order to assess the approaches for the New Zealand patent system regarding the influence of third parties, it is first necessary to understand how a patent system encourages inventions valuable to society. The questions of whether and how third parties should influence the patentgranting process cannot be answered without having the general purpose of a patent system in mind. Possible designs for patent regimes should be orientated to maximise the net benefits to society. ${ }^{29}$

\section{A What is a Patent?}

A patent is a monopoly granted by the state (or Crown) to provide a registered proprietor with the exclusive rights to exploit an invention and to exclude others from doing the same, for a limited time period. ${ }^{30}$ The New Zealand Patents Act 1953 defines the term "Patent" as "a letter patent for an Committee "Review of Intellectual Property Legislation under the Competition Principles Agreement" (Commonwealth of Australia, 2000) 143. 
invention". ${ }^{31}$ By virtue of the "Deed of Letters Patent" issued by the Intellectual Property Office of New Zealand (IPONZ), a patentee has the right to make, use, sell, and exercise an invention and to exclude others from doing so within New Zealand. Since a patent gives an inventor the right to exclude others from using his or her invention, the patent system is a form of reward for the inventor who has applied knowledge and skills to create something new. ${ }^{32}$ In particular, a patent protects the patentee from competition within its scope throughout its entire lifetime. In return for these benefits given by the society, the inventor must fully disclose the invention to the public and must enable the public to put the invention into practice, so that the invention can be used after the expiration of the patent term..$^{33}$ Although monopolies are not desirable in principle, patents are literally monopolies founded upon the concept of a "social contract" between the patentee and the society. ${ }^{35}$

\section{B Justification of a Monopoly}

As patents temporarily create a distortion by preventing others from using an innovation, and because a society will have to bear the costs incurred by such anticompetitive practises, the granting of patents must be justified. Because a monopoly is a "derogation from the common right of freedom of trade" ${ }^{36}$, the right to grant monopolies has always been strictly limited in common law. ${ }^{37}$ Therefore, with respect to intellectual property, only the granting of monopolies for inventions has been recognised as justifiable by the courts and by law. ${ }^{38}$ The reason for this exception was that,

Patents Act 1953, s 2(1).

Craig Allen Nard and R Polk Wagner Patent Law (Foundation Press/ Thomson West, New York, 2008) 7. See Andrew Brown and Anthony Grant, above n 10, 487.

William van Caenegem Intellectual Property Law and Innovation (Cambridge University Press, Port Melbourne, 2007) 63.

Doug Calhoun “'International Developments: Patents and Biotechnology' Appendix B 'Comments on WIPO/UPOV Paper CAJ/XXIV/4 The Interface between Patent Protection and Plant Breeders' Rights"' in The Context for Reform, above n 16, 73, 74. Attorney General (Cth) v Adelaide Steamship Co [1913] AC 781, 793.

See Liardet v Johnson (1778) 1 WPC 53; 62 ER 1000.

See Dracy v Allen (1602) 11 Co Rep 84, 74 ER 1131 (also known as Case of Monopolies) and Statute of Monopolies 1623, 21 Jac I, c 3. 
from the beginning, patents have been considered necessary to provide an incentive for innovation and to reward inventors of important technologies. ${ }^{39}$ The modern rationale for protecting patents is still based on this concept. According to the Agreement on Trade-Related Aspects of Intellectual Property Rights (TRIPS), the objective of patent rights is to promote technological innovation and the dissemination of technology to the mutual advantage of producers and users in a manner conducive to social and economic welfare. ${ }^{40}$ Furthermore, patents seek to encourage innovation by providing incentives to invest in research, to create new inventions, and to increase public knowledge by disclosing new inventions that may be beneficial for society. ${ }^{41}$

\section{Economic Impact of a Patent System}

The economic effect of patents on the welfare of a society has been the subject of much research over the last two centuries. As the topic of this dissertation is the influence of third parties within an existing patent system, it is sufficient only to mention that, based on the economic aspect of patents, scholarly opinion ranges from calls to abandon patent systems to support for increasing their strength. ${ }^{42}$ However, in order to discuss how the parts of a patent system should be designed in order to maximise the benefits to society, it is helpful to consider the main arguments in favour of and in

The first modern patent system was established by the Venetian Patent Decree of 1474, providing an inventor of any novel and ingenious device with a privilege for 10 years in order to promote innovation, see Giulio Mandich "Venetian Patents (1450-1550)" (1948) 30 JPOS 3. See TRIPS, above n 5 , art 7 .

See J M Aubrey "A Justification of the Patent System" in Jeremy Phillips (ed) Patents in Perspective (ESC Publishing Limited, Oxford, 1985) 1; David Vaver "Invention in Patent Law: A review and a modest proposal" in David Vaver (ed) Intellectual Property Rights: Critical Concepts in Law Vol. III (Routledge, London and New York, 2006) 63. See also United States Supreme Court Kewanee Oil Co v Bicron (1974) 416 US 470, 480-481.

However, whether a patent system could really reach this goal, or whether the restriction of competition may instead stifle innovations is the subject of long debates, see generally Wolfgang E Siebeck (ed) Strengthening Protection of Intellectual Property Law in Developing Countries: A Survey of the Literature (The World Bank, Washington DC, 1990). This paper does not enter into this debate. However, most countries worldwide have a patent regime in order to promote innovation. by Robert P Merges Economic of Intellectual Property Law Vol I (Edward Elgar Publishing Ltd, Cheltenham, Northampton, 2007). 
opposition to patent systems in general. Furthermore, it is also useful to reflect on the economic impact of a patent system by reviewing New Zealand's patent system.

\section{Incentive for innovation}

The primary argument in favour of a patent system is that patents provide an incentive for innovation and that without a patent system, fewer inventions would be developed. ${ }^{43}$ In the absence of legal frameworks for patents, anybody could use an innovation and profit from it without incurring the costs of research and development (R\&D). ${ }^{44}$ Without adequate protection, competitors would rapidly imitate successful inventions and prices would drop to the point where inventors, having to bear the costs of research and development, would no longer earn significant profits. ${ }^{45}$ As a result, companies would avoid costs for research and development because inventions would not be profitable enough. ${ }^{46}$ In the end, inventions with high social benefits might be delayed or not be created at all. ${ }^{47}$ Moreover, it has been stated that without some forms of incentive the level of invention "would be too low (sub-optimal)", ${ }^{48}$

The most fundamental criticism of this theory is that patents restrict access to innovation. New inventions with patent protection cannot be freely used by society which results in decrease of social benefits. ${ }^{49}$. As a result, further research and development that could infringe an existing patent is rendered impossible. Therefore, patents may discourage innovation instead

Incentive to invent theory, see Frederic M Scherer and David Ross Industrial Market Structure and Economic Performance (3rd ed, Houghton Mifflin, Boston, 1990); John S McGee "Patent Exploitation: Some Economic and Legal Problems" (1966) 9 JL\&Econ 135; Fritz Machlup An Economic Review of the Patent System - Study of the Subcommittee on Patents, Trademarks, and Copyrights of the Committee on the Judiciary (United States Government Printing Office, 1958). See Andrew Duncan "Economics of Intellectual Property" in Possible Options for Reform, Vol. 2, above n 16, 8-9. Rebecca S Eisenberg "Patents and the Progress of Science: Exclusive Rights and Experimental Use" (1989) 56 U Chi L Rev 1017, 1025. See Machlup, above $\mathrm{n} 43$.

Rebecca S Eisenberg, above n 45, 1025.

Matthew Fisher Fundamentals of Patent Law Interpretation and Scope of Protection (Hart Publishing, Portland, 2007) 136. 
of encouraging it..$^{50}$ In addition, it has been argued that innovations can also be made without societal incentives, promoted only by competition. ${ }^{51}$ Another objection is that patents could distort economic activities, as researchers would only concentrate on areas in which patent monopolies are profitable. $^{52}$ As a result, research might concentrate on what can be protected, not what would be most useful. ${ }^{53}$ Furthermore, as patent monopolies restrict competition, they can result in higher prices, increasing the cost of technology available to the society. ${ }^{54}$ However, if patented products were not more expensive, the profit from selling them would not justify the high costs of research and development, and nobody would invest in the development of new products. In the end, the higher costs for society for patented products also finance the development of new products and processes. ${ }^{55}$ Therefore, “[p]atents protect an individual's or firm's investment in the development of an idea, as much as they protect the invention itself." ${ }^{56}$

\section{Incentive for disclosure}

The other main argument in favour of a patent system is the disclosure of the invention in the patent specification, a description that would otherwise be kept secret in order to prevent imitation. ${ }^{57}$ Without disclosure

Boundaries to Patentability, above n 14, 6 .

See Jack Hirshleifer "The Private and Social Value of Information and the Reward to Inventive Activity" (1971) 61 Am Econ Rev 561.

Scherer and Ross, above n 43, 387; Michael A Gollin Driving Innovation - Intellectual Property Strategies for a Dynamic World (Cambridge University Press, New York, 2008) 42.

For example, according to the Global Forum for Health Research, only 10 percent of the worldwide expenses for global health research are used to for research into 90 percent of the worldwide health problems (10/90 gap); see Commission on Health Research for Development Health Research - Essential Link to Equity in Development (Oxford University Press, Oxford, 1990).

Gollin, above $\mathrm{n} 52,41$.

Adam B Jaffe and Josh Lerner, Innovation and its Discontents How our Broken Patent System is Endangering Innovation and Progress, and What to Do about It (Princeton University Press, Princeton and Oxford, 2004) 40-41.

Ibid, 43 .

Incentive to disclose theory, see Universal Oil Products Co v Globe Oil \& Refining Co, (1944) 322 US 471, 484; Grant v Raymond, (1832) 31 US 6 Pet. 218, 247; Scherer and Ross, above n 43, 381; Machlup, above n 43, 32 et seq, 53 and 76. 
of the invention, society has no access to this new knowledge, with the result that research may be duplicated, wasting money and resources. ${ }^{58}$

On the other hand, although a disclosure of an invention represents a burden for the applicant in obtaining a patent, it is often questionable whether this disclosure conveys enough information to put the invention to practical use without supplementary knowledge. ${ }^{59}$ However, trade secrets may also be used to protect inventions without disclosure. In this case, it is questionable whether it is inapplicable in case exploration requires demonstration of the invention. Nevertheless, as it is generally impossible to sell an idea without a demonstration of how it works, this disclosure may destroy the monopoly if no specific legal protection exists. ${ }^{60}$

\section{$3 \quad$ Intermediate result}

As analysed above, good arguments exist against patent systems, in addition to those in favour of them. It cannot be definitively stated that it would be better to abolish patent systems or that it would be best to protect patents in order to encourage research and development. However, although it is clear that patent systems are to some extent imperfect, it nevertheless seems that providing patent protection is "the best policy solution man can devise to the difficult trade-off between, on the one hand, maintaining incentives for investment and, on the other hand, fostering the diffusion of new technology's benefits ...". ${ }^{61}$. As a result, even though a patent system can have significant negative economic effects, most countries worldwide (New Zealand included) provide patent protection for inventions.

Martin J Adelman "Property Rights Theory and Patent - Antitrust: The Role of Compulsory Licensing" (1977) 52 NYU L Rev 977, 982.

It has been stated that patent applicants withhold information from patent specifications in order to protect inventions through trade secrecy, see Machlup, above n 43, 32-33.

Kenneth J Arrow "Economic Welfare and the Allocation of Resources for Invention" (1959) Economic Division of the RAND Corporation, Paper P-1856-RC, 9.

Frederic M Scherer New Perspectives on Economic Growth and Technological Innovation (Brookings Institution Press, Washington, 1999) 58. 
$4 \quad$ How does the economic impact of patents influence the review process in New Zealand?

Considering the negative aspect of the economic impact of patent systems, the question could arise in the course of the reform process of whether New Zealand still needs a patent system at all, or whether it would be better to abolish it.

First, abolishing the patent system in New Zealand has never seriously been considered. All reviews of the New Zealand patent system have been mostly focused on the controversial elements of patent law. ${ }^{62}$ One of the reasons for this is that the establishment of a legal framework for the protection of inventions by patents is a principal part of New Zealand's governmental policy promoting innovation and fostering the national economy. ${ }^{63}$ As Hon Mr Justice Gault states: ${ }^{64}$

... to provide a climate for New Zealand's industrial, commercial and intellectual development. [...] the laws must be considered as a part of a wider policy which extends to encouragement of research and development, and fiscal policies towards investment, royalties and the like.

Second, an abolishment of the patent system in New Zealand is also unthinkable, not only because this would mean a breach of international obligations such as the TRIPS Agreement ${ }^{65}$ but also because New Zealand would face the risk that other countries and multinational companies that use patents might avoid its market. This would have serious consequences for a small economy such as New Zealand, as it strongly depends on international trade and importing new technologies. As Professor Grant Hammond states, with respect to the specific situation in New Zealand: ${ }^{66}$

See generally the reports regarding the reform process in New Zealand, citations under $\mathrm{n}$ 13,14 and 16.

Alan Bollard and David Harper Research and Development in New Zealand: A Public Policy Framework (NZIER, Wellington, 1987) Research Monograph 39, 3.

Hon Gault "Recent Experience of Intellectual Property Law Reform" in The Context for Reform, above n 16, 21, 25. TRIPS, above $\mathrm{n} 5$.

Prof. Grant Hammond "Intellectual and Industrial Property Philosophy, Process and Problems" in The Context for Reform, above n 16, 29, 34. 
It is far from clear that there is any national commitment in New Zealand to the development of a genuinely innovative technologydriven society. On the other hand, it may well be that New Zealand is less of a net importer of technology than is commonly supposed. There are some clear instances (for example in the agriculture sector) of world leadership in technology which would require strong support rights. And protection may be needed as much for technology transfer to us, as anything else.

As a result, it is incontrovertible that New Zealand could not easily abolish its existing patent system. However, the economic impact of the system and its negative effects should nevertheless be taken into consideration in the review process. These effects are particularly relevant for New Zealand, because a large number of New Zealand's patents are granted to non-residents. ${ }^{67}$ As a result, the majority of patents protect foreign inventions from imitation by local industry ${ }^{68}$ Much of the benefits of New Zealand's patents might thus be flowing overseas. ${ }^{69}$

Therefore, it can be concluded that the question is not whether New Zealand needs a patent system at all; the question that should be addressed by the review process is how the existing patent system can be revised to maximise the benefits for New Zealand's society.

\section{Keeping the Balance}

As the very granting of a patent creates welfare losses, a patent system should above all ensure the balance between capitalising on inventions realising the benefits of excludability and non-competition - and the interest

Patents Bill 2008, (Explanatory note), 51.

A comparable economic situation exists in Australia, where several reviews of the patent system have been carried out from an economic perspective. See Industrial Property Advisory Committee Patents, Innovation and Competition in Australia (IPAC, Canberra, 1984); Thomas D Mandeville, Donald M Lamberton and E J Bishop Economic Effects of the Australian Patent System (Australian Government Publishing Service for Patents, Trade Marks and Designs Office, Canberra, 1982); Bureau of Industry Economics The Economics of Patents (AGPS, Canberra, 1994); Intellectual Property and Competition Review Committee Review of intellectual property legislation under the Competition Principles Agreement (Commonwealth, Canberra, 2000).

Patents Bill 2008 (Explanatory note), 51. 
of the public to obtain new technologies. ${ }^{70}$ In the end, a patent system must balance the interests of all concerned: the inventor and investor, their competitors, and society.

The Supreme Court of the United States noted in $1833:^{71}$

The patent law was designed for the public benefit, as well as for the benefit of inventors. For a valuable invention, the public on the inventor's complying with certain conditions give him, for a limited period of time, the profits arising from the sale of the thing invented. This holds out an inducement for the exercise of genius and skill, in making discoveries which may be useful to society and profitable to the discoverer.

An ideal patent system keeps the balance by granting patents only for true inventions. ${ }^{72}$ From a social welfare perspective, only new and useful inventions that would not have been made without a patent system should be granted patents, because only these rights will be beneficial to society. ${ }^{73}$ This principle of patent law is as old as the British Statute of Monopolies from 1623, generally precluding protection of intellectual creations unless good cause can be shown. ${ }^{74}$ In theory, this means that only efficiencyenhancing rights for true inventions should be granted.

The patent office should avoid granting patents too easily and too broadly, because patents can be used as weapons to harass competitors, to increase prices, or to limit access to goods at society's expense. A patent system as an instrument of economic policy "is intended to foster, not to harass, industry ..." ${ }^{75}$ As previously mentioned, a patent system is only

See Claude Barfield and John E Calfee Biotechnology and the Patent System: Balancing Innovation and Property Rights (The AEI Press, Washington DC, 2007); D P O'Brien "Patents: An Economist's View" in Jeremy Phillips (ed) Patents in Perspectives (ESC Publishing Limited, Oxford, 1985) 32, 35.

Shaw v Copper (1833) 32 US 292, 318.

Jaffe and Lerner, above n 55, 8.

Paul H Jensen and Elizabeth Webster "Achieving the Optimal Power of Patents Rights" (2004) Intellectual Property Research Institute of Australia, Working Paper 15/04, 2.

Robert Merges “As Many as Six Impossible Patents before Breakfast” (1999) 14 Berkeley Techn L J 577, 585.

Union Foundries Ltd's Application, 18 August 1927, per Commissioner Atkinson. 
justifiable if it rewards true invention that increases the technological prosperity of society. ${ }^{76}$

If a patent is granted for an invention that is not a true invention, the society must bear the high social cost arising from creating a monopoly without obtaining a benefit. Not only must the public pay higher prices for products because competition is restricted, but also technologies that would be otherwise freely accessible cannot be used to develop new products. Therefore, the aim of patents to encourage invention may not be achieved, sending the system out of balance.

Since true inventions are hard to identify, patent systems commonly prescribe legal requirements for the patentability of an invention in order to justify granting a monopoly and to dispel uncertainty. ${ }^{77}$ Three criteria are now internationally accepted to identify a true invention: an invention is eligible for patent protection if it is new, if it involves an inventive step, and if it is useful. ${ }^{78}$ An invention is new if the subject matter of the invention has not been known to or used by the public before the filing date of the application. An invention involves an inventive step if it is not obvious to a skilled person in the related discipline; it is useful if the inventor can identify a practical use for the invention.

\section{E Is the New Zealand Patent System in Balance?}

New Zealand patent law also lists legal requirements for the patentability of an invention. However, the pertinent question is whether or not the legal requirements in New Zealand are sufficient to keep the patent system in balance by ensuring that only true inventions are granted patents.

First, the current approach of New Zealand patent law in determining whether an invention is patentable is based on provisions of the Patents Act

Fisher, above n 48, 93.

J M Aubrey "A Justification of the Patent System" in Jeremy Phillips (ed), above n 41, 1, 4. Under Article 27 of the Agreement on Trade Related Aspects of Intellectual Property Rights (TRIPS), patents are available if "they are new, involve an inventive step and are capable of industrial application." The note to Article 27 states that "the terms "inventive step' and 'capable of industrial application' may be deemed by a Member to be synonymous with the terms 'non-obvious' and 'useful' respectively.", TRIPS, above n 5 , art 27. 
1953 and on case law from the courts. Under the New Zealand Patents Act 1953, a patent is only obtainable for inventions that are a "manner of new manufacture". ${ }^{79}$ This term is not self-explanatory and has been variously interpreted by the courts, which have, for example, excluded specific subject matters from patentability - including mathematical logarithms, principles of discovery, mere schemes or plans, and methods of medical treatment of humans ${ }^{80}$ However, the patentability of specific inventions, such as patents for treatment of humans or business method patents could raise questions of policy and practicability that are difficult for the courts to resolve. ${ }^{81}$ With respect to the controversial topic of the patentability of medical treatments and Swiss-type claims in New Zealand, his Honour Hammond J stated: ${ }^{82}$

For myself, I think that Parliament would have to legislate in the clearest and most unequivocal terms before New Zealand law could be taken as having gone any further in the direction of unlimited protection of pharmaceutical patents, than the allowance of Swiss-type claims (which, in fairness to Parliament, are really a Court-generated device). And whether it should do so, strikes me as a particularly difficult problem of public policy which lies well beyond the institutional competence of this Court.

Therefore, in some sensitive matters of the patent law, it would be preferable if Parliament would amend the existing legislation and implement provisions defining which subject matter is patentable and which should be excluded from patentability. ${ }^{83}$

The definition of the term "invention" in section 2(1) of the Patents Act 1953 includes the term "manner of new manufacture" referring to section 6 of the Statute of Monopolies 1623 , above $\mathrm{n} 38$.

For the definition of "new manufacture", see High Court of Australia National Research Development Corp v Commissioner of Patents (1959) 102 CLR 252 (HCA) [NRDC].

See also for Australia, Bristol-Myers Squibb Company v F H Faulding \& Co. Ltd (2000) 46 IPR 553, 596, where Finkelstein J stated: “... that is a matter that should be resolved by the Parliament."

See Pfizer Inc v Commissioner of Patents, above n 11, para 128, per Hammond J.

According to this, it is highly controversial in New Zealand whether or not the Patents Act should provide a definition of invention or specific exclusion provisions, see Boundaries to Patentability, above n 14, 6. For criticism of the opinion held in the report, see Jeremy Blum "Why 'Inventions' Should Be Removed from New Zealand Patent Law" (2006) 64 Intellectual Property Forum 22; see generally Doug Calhoun "Commodity Hedging, Trusts and Broomstick Putting: What is an Invention?" (2009) 5 NZIPJ 545. 
Second, in the process to justify the grant of a patent in New Zealand, it is doubtful if the existing examination standards are high enough to avoid granting unacceptable numbers of "bad" patents. ${ }^{84}$ The Intellectual Property Office of New Zealand (hereafter IPONZ), according to New Zealand's relatively low examination standards, examines patent applications only for novelty and the adequacy of the description. ${ }^{85}$ Unlike most other patent regimes worldwide, there is no requirement at the examination stage for the examiner to determine whether the application involves an inventive step or is useful. ${ }^{86}$ However, lack of an inventive step and lack of utility are grounds to challenge the application in an opposition or revocation proceeding. ${ }^{87}$ In addition, although an invention needs to be new in order to be patentable in New Zealand, novelty is only examined on the limited prior art base of the local novelty standard. ${ }^{88}$ Moreover, under the current patent regime of New Zealand, applicants are generally given the benefit of the doubt. ${ }^{89}$

Since the standards of examination are less strict, it seems to be easier to obtain patent protection in New Zealand than in other countries, and the scopes of the patents may be broader. ${ }^{90}$ Unfortunately, there are no statistical data available as to how many applications have been refused in other countries but granted in New Zealand due to the different levels of examination standards.

Because the examiner has no right to refuse an application that is indeed new but does not involve an inventive step, it is possible that patents may be granted in New Zealand that could not have obtained patent protection under a patent regime that included the examination of

As used in this paper, a "bad" patent is one that should not have been issued because the claimed scope is too broad or the patent is not valid.

Patents Act 1953, ss 13-14.

Ibid, ss 13-14; see otherwise requirements of TRIPS as an international standard for patenting inventions, above $\mathrm{n} 5$, art 27.

Patents Act 1953, ss 21(1)(e), 41(1)(f) and 42(1).

Ibid, s 2(1).

Pharmaceutical Management Agency Ltd (Pharmac) $v$ The Commissioner of Patents [2000] 2 NZLR 529.

Hon Christopher Finlayson, Attorney-General in first reading, above n 12, 2884; Patents Bill 2008 (Explanatory note), 52. 
obviousness. ${ }^{91}$ Furthermore, such patents could also survive an opposition procedure because of the benefit-of-doubt approach. There have been several cases in New Zealand in which opposition procedures have failed even though the Assistant Commissioner concluded that the invention claimed appeared to be obvious, because section 21(1)(e) of the Patents Act 1953 requires that the invention clearly does not involve an inventive step. ${ }^{92}$ Following the benefit-of-doubt approach, the Assistant Commissioner allows applications to proceed unless in no reasonable view the requirements of the Patents Act 1953 can be met. ${ }^{93}$ Therefore, it seems that particularly the lack of examination for obviousness and the benefit-ofdoubt approach result in the IPONZ granting more patents with doubtful validity or a broader scope than would be possible in other countries. ${ }^{94}$

Additionally, the local novelty standard allows the granting of patents for inventions that may already be known outside New Zealand, as long as prior art material is not accessible within its borders. ${ }^{95}$ This has the consequence that "patents may be granted for inventions that already exist or where they are obvious variations on existing technology"96 as Hon Christopher Finlayson, Attorney-General, stated.

Consequently, the less strict examination standards and the benefit-ofdoubt approach create the potential that patent protection may be obtained for technology that is freely accessible elsewhere, and even more patents of

See Anton Blijlevens "What is obvious may not seem obvious: Obviousness in New Zealand and Australia" (2008) 5 NZIPJ 425.

For example, see Delaval Holding AB v Waikato Milking Systems NZ Ltd (23 June 2008), Intellectual Property Office, P 2/2008; Fernando Vincente Ruiz Ocampo v New Zealand Racing Board (8 December 2008), Intellectual Property Office, P 7; Bernard Charles Sherman v Merck \& Co, Inc. (13 August 2007) Intellectual Property Office P 21/2007; Ewan Malcolm Campbell v Agrissentials Ltd (9 May 2007) Intellectual Property Office P 13 .

$R v$ Patents Appeal Tribunal, ex parte Swift and Co [1962] RPC 37 cited in Pharmaceutical Management Agency Ltd (Pharmac) v The Commissioner of Patents, above n 89, para 15 Gault J.

See Hon David Parker, first reading, above n 12, 2886; Patents Bill 2008 (Explanatory note), 52. Due to this, Australia replaced the "benefit of doubt" test at examination by the "balance of probabilities" test, in which the Commissioner needs to be satisfied that the invention is new and inventive, see Jill McKeough, Andrew Steward and Philip Griffith, Intellectual Property in Australia (3rd ed, LexisNexis Butterworth, Chatswood, 2004) 347. Patents Act 1953, ss 13(1) and 2(1).

See Hon Christopher Finlayson, Attorney-General, first reading, above n 12, 2884. 
doubtful validity may be granted at the expense of New Zealand's society. ${ }^{97}$ Overall, the patent regime in New Zealand seems to be out of balance.

\section{F How Could the New Zealand Patent System Be Balanced?}

In order to restore the necessary balance, a patent system should avoid granting overly broad patents and should implement standards for obtaining a patent. As it is unrealistic to completely avoid the grant of undesirable patents, a good patent system should aim to minimise the amount of these so-called "bad" patents to an acceptable level by increasing the required quality of patents. ${ }^{98}$

Following such logic, New Zealand's patent system would be in balance if the level of "bad" patents granted were as low as possible. By improving the quality of its patents, the market could revive its vitality by restoring confidence in the validity of its patents. ${ }^{99}$ The value of patents may thereby increase, and more financial resources may be available to promote further research and development. Moreover, a restored confidence in the validity of New Zealand's patents also has the potential to increase imports of new technologies from overseas, because importers would have strong rights to protect their inventions. In conclusion, enhancing the quality of its patents seems to be a good way to keep New Zealand's patent regime in balance.

\section{ENHANCING THE QUALITY OF PATENTS}

\section{A What Is Meant by Patent Quality?}

The quality of patents has been a long-time subject for research worldwide. Economists who examine the outcome of the patent examination

See Hon David Parker, first reading, above n 12, 2885, 2886; Patents Bill 2008 (Explanatory note), 52-55.

See Jensen and Webster, above n 73; Dietmar Harhoff "The Demand for Patents and the Evolution of Patent Quality" (paper presented to Advancing Knowledge and the Knowledge Economy Conference, National Academy of Sciences, Washington, DC, 11 January 2005).

Mark D Janis "Rethinking Reexamination: Towards a Viable Administrative Revocation System for U.S. Patent Law" (1997) 11 Harv J Law \& Tech 1, 23. 
process - the granted patent - have carried out most of this research. ${ }^{100}$ According to their work, the validity of patents defines the quality of patents. Low quality patents, or so-called "bad" patents, are improperly granted patents that should have been "weeded out after a reasonable investment of effort, but [were] not." ${ }^{101}$ In contrast, high quality patents are valid patents that survive validity challenges and have improved chances of being reliably enforced in court. ${ }^{102}$ Ensuring high quality of patents increases the level of certainty and the value of the patents, to the satisfaction of both the patentee and society. ${ }^{103}$ Thus, the higher the quality of New Zealand patents, the greater the benefits for all concerned.

\section{B How Can the Quality of a Patent Be Enhanced?}

As it is clear that a patent system should only allow valid patents to survive in the market, the pertinent question is what needs to be done to enhance the quality of patents. This has been the subject of long debates. ${ }^{104}$ The purpose of this dissertation is not to examine this debate in detail but to demonstrate which approaches to prevent the creation of invalid or overly broad patents could be appropriate for New Zealand.

\section{Patent Office or Courts - Who would be the best to eliminate "bad" patents?}

Generally speaking, there are two possible stages that could separate true inventions from those that should not obtain patent protection: the administrative stage and the judicial stage.

First, as patents are the outcome of the Patent Office, one approach would involve changing the procedures of this office so that "bad" patents

Chris Dent "Decision-Making and Quality in Patents: An Exploration" (2006) 28 EIPR 381.

Robert Merges, above n 74, fn. 6.

John R Thomas "The Responsibility of the Rule-Maker: Comparative Approaches to Patent Administration Reform" (2002) 17 Berkeley Techn LJ 727, 730.

Dent, above n 100, 382.

For further research, see Merges, above n 74, 590; Stephen Merill "Improving Patent Quality: Connecting Economic Research and Policy" in Patents, Innovations and Economic Performance (OECD Conference Proceedings, Paris, 2004). 
would not be so easily granted. This approach is based on the assumption that the quality of patents would automatically increase if the error rate of the Patent Office regarding the patentability of inventions decreased.

Second, the courts have traditionally had the function of reviewing patents and removing invalid patents from the market. The final decisions of the courts on whether or not a granted patent meets the requirements of patent law could enhance the quality of patents, ${ }^{105}$ if as many invalid patents as possible could be brought before the courts - for example, in validity actions. This approach is based on the assumption that it would be more effective to examine only those inventions that are to be enforced than all inventions filed.

Both approaches will be analysed with regard to their advantages and disadvantages for New Zealand.

\section{Patent Office}

(a) Increasing examination standards

One way to enhance the quality of patents granted would be to increase the examination standards of the Patent Office. In most patent regimes, the Patent Office does not grant patents until it examines the invention with respect to its patentability. An ideal approach would be for the patent office to grant desirable patents only for novel and non-obvious inventions - that is, valid patents. ${ }^{106}$ Unfortunately, it is hard to identify such inventions. In addition, it is the goal of the examination procedure to differentiate those inventions that should be patented from those that should not, the standards of examination help the examiners to identify these. While most countries apply the same criteria for patentability, there are significant differences in the standards of examinations by the Patent Offices. ${ }^{107}$ That means that a patent may be granted for an invention by one

See McKeough, Steward and Griffith, above n 94, 404.

Merges, above n 74, 590.

Paul H Jensen, Alfons Palangkaraya and Elizabeth Webster "Patent Application Outcomes across the Trilateral Patent Offices" (Melbourne Institute of Applied Economic and Social Research, Melbourne, 2005) 2. 
Patent Office, but the same invention would not obtain patent protection from another Patent Office. ${ }^{108}$

One way to avoid the grant of invalid patents would therefore be a rigorous examination including particularly high standards. ${ }^{109}$ In fact, the higher the threshold for obtaining a patent (as defined by the examination standards), the more certain it is that the patent granted is a true invention. ${ }^{110}$

(b) Practicability of a rigorous examination

In addition to the threshold for patentability, the quality of examination procedures also strongly depends on the ability of the patent office to find prior art. As the examination of novelty and non-obviousness of a patent application is based on what was known before a specific date, the examination procedure includes the patent office's search for prior art. It is unrealistic for a patent office to be aware of all prior art, but a high quality examination means that the patent office must know as much prior art as possible. This means that the lowest error rate for patentability would be attained if the patent office performed an in-depth search for prior art for each patent application before granting a patent. ${ }^{111}$ However, such in-depth searches require extensive resources - manpower, time, and money.

Furthermore, the diversity and complexity of patent applications have drastically changed in recent decades. New areas of patenting, such as patents for software or business methods, make it more difficult for an examiner to decide whether an application is patentable or not. ${ }^{112}$ As most examiners have expertise in traditional fields, such as engineering or biotechnology, they may lack the knowledge necessary to examine a

This is the reason why one objective of the patent harmonisation agenda is to harmonise international examination procedures, see Patent Law Treaty (PLT) (1 June 2000) 39 ILM 1047 [PLT].

Note, however, that even rigorous examination standards would not reduce the granting rate of "bad" patents to zero, because of the random error rate. Even with the strictest examination, a chance exists that the courts will later find a patent invalid. However, the error rate of the Patent Office would be significantly lower. See Jensen and Elizabeth Webster, above $\mathrm{n} 73,7$.

Ibid.

Merges, above n 74, 590.

Paul H Jensen, Alfons Palangkaraya and Elizabeth Webster, above n 107, 7. 
business method application in a new technological field. ${ }^{113}$ Similarly, prior art information for new technologies may also lie outside of the traditional research areas of Patent Offices. ${ }^{114}$ It has thus become increasingly more difficult and time-consuming to conduct searches and to find relevant prior art.

A rigorous examination by the patent office with high thresholds of patentability and an in-depth research for prior art might be an effective way to enhance the quality of patents, but it also has the potential to overburden the resources of the patent office.

(c) A rigorous examination as solution for New Zealand?

The administrative body in New Zealand to examine, grant, and register patents is the Intellectual Property Office of New Zealand (IPONZ). ${ }^{115}$ Before a patent is granted, the examiners at IPONZ carry out an examination of the application. As discussed above, the standards of examination in New Zealand are currently lower than in other countries, allowing patents broader in scope. ${ }^{116}$ The introduction of a rigorous examination procedure for New Zealand could help prevent the grant of invalid or overly broad patents. Unfortunately, a rigorous examination procedure, based on an in-depth search for prior art, requires extensive resources of expertise and money.

Currently, the IPONZ is capable of examining, to at least an acceptable extent, specifications in any field of art. However, due to its size, New Zealand's resources of experts in arts, sciences, and finances are limited. ${ }^{117}$ The Commissioner of Patents, Trade marks and Design stated in the 2007-2008 annual report of the IPONZ that it has been difficult to

Jay P Kesan and Andres A Gallo "Why 'Bad' Patents Survive in the Market and How Should We Change? - The Private and Social Cost of Patents" (2006) 55 Emory L J 62, 67. Many new developments in computer programs, for example, can not be found in patent documents or academic publications. See Julie E Cohen "Reverse Engineering and the Rise of Electronic Vigilantism: Intellectual Property Implications of 'Lock-Out' Programs" (1995) 68 S Cal L Rev 1091, 1178.

Intellectual Property Office of New Zealand Annual Report 2007-2008 (Wellington, 2008) 4.

See above under Part II. E.

Patents Bill 2008 (Explanatory note), 54. 
provide a sufficient amount of experienced examiners because of the more complex and technically challenging applications in recent years. ${ }^{118}$

As a consequence of the increasing number of patent applications, examiners worldwide have only a limited amount of time for conducting a prior art search and making a decision regarding an application's patentability. ${ }^{119}$ Accordingly, it has been said that "the prior art search and evaluation during the original examination $[\ldots]$ cannot be exhaustive" ${ }^{120}$. In particular, it has been difficult to conduct in-depth searches in cases in which the prior art includes references other than printed publications. ${ }^{121}$

A further issue is that, due to the size of the IPONZ, its examiners do not have the opportunity to specialise in a specific field of art or science, in contrast to the larger patent offices in the United States or the European Union. ${ }^{122}$ Consequently, the IPONZ may lack specialised knowledge of the prior art in some fields, particularly in areas of new technologies, such as telecommunications or computer science.

Finally, it can be assumed that the IPONZ would not have the resources to conduct the in-depth search for prior art that would be required by a rigorous examination standard. As both financial resources and the number of experts are limited in New Zealand, it is perhaps unreasonable to establish such a rigorous examination standard. Under the current Marks and Designs to the Minister of Commerce for the Years Ended 30 June 2008" (IPONZ, Wellington, 2008) 3. doubled, from 3,828 in 1995/1996 to 8,653 in 2007/2008, see IPONZ "Report of the Commissioner of Patents, Trade Marks and Designs to the Minister of Commerce for the year ended 30 June 2000" (IPONZ, Lower Hutt, 2001) 8; IPONZ "Report of the Commissioner of Patents, Trade Marks and Designs to the Minister of Commerce for the year ended 30 June 2009" (IPONZ, Wellington, 2010) 7. Qin Shi "Reexamination, Opposition, or Litigation? Legislative Efforts to Create a PostGrant Patent Quality System" (2003) 31 AIPLA Q J 433, 436.

For example, this is true for software-related inventions, because in this field of technology, developments are commonly discussed in newsgroups or other online forums. Therefore, the United States Patent and Trademark Office has launched an alliance with the Open Source Community to get access to software codes, see USPTO "USPTO partners with the Open Source Community to expand examiner access to software codes" (10 January 2006) Press Release. Design and Trade-Marks in "Report of the Commission" (Government Printer, Wellington, 1950) 23-24. 
circumstances, a rigorous examination procedure may make the patentgranting process in New Zealand much more time-consuming, which could result in a huge backlog of patent applications.

On the other hand, while the current, less strict examination standards in New Zealand may be cheaper to administer, they also introduce uncertainty with regard to the validity of a patent. ${ }^{123}$ Hence, it would be a first step in the right direction if New Zealand's examination standards were raised to an internationally appropriate level. ${ }^{124}$ However, as small as these changes in the examination standards would be, they would also have the potential to overburden the resources of the IPONZ. The establishment of a more rigorous examination procedure might therefore help increase the quality of patents in New Zealand, but the higher examination standards would also risk impacting the ability of the IPONZ to grant patents in a reasonable amount of time.

To avoid the grant of "bad" patents, increasing the standards of examination is a good solution for New Zealand. However, the implementation of stricter examination standards is only possible within the capacity of the IPONZ to carry out such examinations.

\section{Courts}

(a) A registration system without examination by the patent office ${ }^{125}$

An additional way to improve the quality of patents in New Zealand would be to fully shift the burden of examination from the patent office to the courts. In this model, the government would register patents without examination. It would then be the sole task of the courts to make detailed

Jensen and Webster, above $\mathrm{n} 73,4$.

See speeches, first reading, above $n 12$.

A modification of a registration system has been recently adopted in Australia with the "innovation patents". These types of patents have a maximum term of 8 years and only require an innovative step, not an inventive step. The Patent Office grants these patents without substantial examination for validity, after a formality check. However, an innovation patent cannot be enforced once a substantial examination has been carried out by the Patent Office in order to certify the patent. 
validity determinations for those patents challenged by private parties and to decide whether they fulfil the requirements of patent law. ${ }^{126}$

(b) Practicability of a registration system

The intent underlying this approach is to avoid the high costs of a rigorous examination by the patent office. It is based on the assumption that these costs would generally be higher than the cost of court litigations in those few cases in which a patent is challenged and disputable. ${ }^{127}$ As Mark Lemley stated, "[b]ecause so few patents are ever asserted against a competitor, it is much cheaper for the society to make detailed validity determinations in those few cases than to invest additional resources examining patents that will never be heard from again." ${ }^{28}$ By contrast, under a rigorous examination concept, the society must bear the examination costs for all patent applications, although most patents turn out to have little commercial value and may simply lapse because the patentee does not pay renewal fees. ${ }^{129}$ A rigorous examination process could help avoid the high social costs that arise from erroneous decisions of the patent office in granting invalid patents; however, the society must instead endure higher examination costs and more time-consuming procedures. ${ }^{130}$ The question is which alternative is better.

One relatively unsuccessful attempt at such a registration system for patents was tried by the United States in the $17^{\text {th }}$ and $18^{\text {th }}$ centuries. ${ }^{131}$ Unfortunately, under this registration system, not all invalid patents were removed from the register, as challenging patents was too expensive for private citizens. As a result, the social costs arising from invalid patents remaining in the register were much higher than expected, since threats

See F Scott Kief "The Case for Registering Patents and the Law and Economics of Present Patent-Obtaining Rules" (2003) 45 BCLRev 55.

Ibid, 70 .

Mark Lemley "Rational Ignorance at the Patent Office" (2001) 95 Northwestern L Rev 1495, 1497.

Van Caenegem, above n 34, 68.

Jensen and Webster, above n 73, 4.

See Edward C Walterscheid "The Winged Gudgeon - An Early Patent Controversy" (1997)

79 JPTOS 533. 
based on invalid patents were substantial enough to create distortions in the market. ${ }^{132}$

Therefore, for a registration system to function successfully, it is imperative that all invalid patents are actually removed from the register; otherwise, even invalid patents can be used to harass competitors. For example, patentees could use invalid patents to approach competitors and demand that they are obligated to pay licenses fees. In many cases, they could target small companies without the financial resources to support the cost of litigation. Even if the small company believes that the patent is invalid, it may eventually opt for a settlement agreement rather than risking expensive patent litigation. ${ }^{133}$

Unfortunately, under the registration model, chances are good that invalid patents will remain in the register, as they can only be eliminated by the courts. Because the process of patent litigation is expensive and timeconsuming, third parties may avoid the legal system to circumvent spending time and money. In particular for technology-based cases, because the courts are not necessarily well-trained in developing fields, the risk of erroneous decisions is high. This might necessitate an appeal of a preliminary decision, with the effect of increasing costs and time spent. ${ }^{134}$ As the cost for seeking a review of a patent before a court might be higher than paying royalties, the third parties may try to reach private agreements or use arbitration procedures instead of going to court. As a result, an invalid patent can easily remain in the register, distorting competition.

(c) A registration system as solution for New Zealand?

In consideration of the limited resources of the IPONZ, a registration system for New Zealand is worth consideration. This would require first and foremost courts that are equipped to carry out in-depth patent examinations. As New Zealand does not have specialised courts for patent litigation and judges generally do not have the technological background to decide

Merges, above n 74, 586.

See Jeffe and Lerner, above n 55, 13-15.

Merges, above n 74, 595. 
whether a patent is valid or not, the courts would need the help of experts. However, the same problems regarding limited resources of experts and money would simply be shifted from the IPONZ to the courts, without any real resolution.

Even if only patents with economic value were examined by the courts, lowering the overall expenses for examinations, the social cost arising from invalid patents remaining in the register would still be higher. Therefore, under existing circumstances, using only patent litigation to eliminate invalid patents is not a feasible way for New Zealand to enhance the quality of its patents.

\section{$4 \quad$ Intermediate result}

As shown above, neither the approach based only in the Patent Office nor the solely judicial approach would be advantageous for New Zealand. The existing two-tier system with IPONZ and the courts acting together in order to eliminate "bad" patents might therefore be the best solution. ${ }^{135}$ The IPONZ has the experts and the technological knowledge required to decide whether or not a patent should be granted. The courts can make detailed validity determinations in cases where patents are enforced.

However, analysing both approaches also shows that the core problem in enhancing the New Zealand's patent quality is its limited resources in expertise and money. A rigorous examination process might be the best solution for quality enhancement, but it also has the potential to overburden the resources of the IPONZ.

Therefore, it seems that the question is not at which stage it would be most effective to eliminate "bad" patents, but rather how to revise the existing examination procedure and the review system without overburdening New Zealand's public authorities and resources. 


\section{ENHANCING THE QUALITY OF PATENTS BY THIRD PARTIES}

\section{A Involving the General Public In Order to Enhance the Quality of Patents}

$1 \quad$ Giving third parties influence

One of the most common strategies used to enhance the quality of patents is to include the private sector in the examination procedure. ${ }^{136}$ Obtaining a patent is normally a process between two parties: the applicant who applies for a patent and the government that grants it. In order to enhance the quality of patents, it could perhaps be advantageous to involve the general public or competitors as third parties in the examination procedure. This model is based on the assumption that a division of labour between the patent office and the private sector may improve the quality of the examination procedure, by utilising the knowledge and experience existing outside the patent office. ${ }^{137}$

\section{Practicability of third party influence}

As discussed above, the question whether a patent should be granted or not is primarily based on the analysis of the prior art. ${ }^{138}$ The quality of the examination procedure therefore strongly depends on the ability to find as much relevant prior art material as possible.

The concept of involving third parties is based on the idea that the general public, and competitors in particular, may have better information about prior art than the patent office or the courts. ${ }^{139}$ For example, a firm operating in the same industry as the applicant will probably be better aware of whether an invention is truly novel and non-obvious. ${ }^{140}$ In order to improve the search for relevant prior art, third parties could provide the

Most patent regimes worldwide allow third parties to exert an influence on the granting procedure, see above IV. B.

Merges, above n 74, 596.

In particular, the determination of whether an invention is novel or non-obvious requires knowledge of what was already known at the date of priority.

Merges, above n 74, 605.

Ibid. 
Patent Office or the courts with relevant information concerning the prior art of the patent applications, information which otherwise might not have been considered.

Involving third parties would permit the search of prior art to be more exhaustive, with the effect that fewer "bad" patents would be granted or survive in the market. This model would also allow a more thorough analysis without increasing the examination costs.

Unfortunately, such an approach involves the risk that these third parties would use their influence in the examination procedure in order to delay the granting of patents or infringement procedures. In such a scenario, the patentees would be kept from exploiting their patents, the value of the patents could decrease, because the patentees are withheld to exploit their patents and further innovation could therefore be stifled. Furthermore, this approach would only work if the third parties actually provided useful information to the patent office and courts.

In the end, the influence of third parties may help prevent the grant of overly broad or invalid patents, but such a system needs to balance the interests of both sides - the applicant or patentee and the third parties.

\section{$3 \quad$ Third party influence as a solution for New Zealand}

Given the current circumstances in New Zealand with regard to the limited resources of the IPONZ and the courts, using the knowledge and experience of third parties in order to enhance the quality of New Zealand's patents may be the best solution.

With the help of third parties, the quality of the examination procedure increases, as more prior art information will be available. This is particularly important for New Zealand, because if it increases its standards of examination by establishing an absolute novelty standard (as is planned), prior art information would need to be searched worldwide. ${ }^{141}$ Furthermore, for patents involving new technologies, expert knowledge that may be 
currently missing in the IPONZ could be incorporated by involving third parties in the examination procedure.

With more and better prior art information, the rate of invalid patents granted may decrease without incurring the high social cost of a rigorous examination procedure by the patent office. ${ }^{142}$ The mixture of governmental and private expenditures to determine the validity of patents appears to be the ideal solution to enhance the quality of patents in New Zealand.

\section{B What Instruments Does a Third Party Have to Influence the Grant of a Patent?}

Although it seems clear that using the knowledge and experience of third parties would be a good way to improve patent quality, there is a controversy regarding how much influence a third party should have and at which stage of the process. ${ }^{143}$

Most worldwide patent systems - including New Zealand's - allow third parties influence in the examination procedure and provide instruments for this in their patent laws. ${ }^{144}$ However, there are significant differences between these different instruments with regard to when third parties are allowed to join the process and how much influence they can have.

In order to identify how third parties can help enhance the quality of patents in New Zealand, it is useful to know the types of third-party instruments that have already been developed and applied by patent regimes worldwide.

143 See, for example, comparative studies such as Fiona Rotstein and Chris Dent "Third Party Patent Challenges in Europe, the United States and Australia: A Comparative Analysis" (2009) University of Melbourne Legal Studies Research Paper No. 428; Stuart Graham and Dietmar Harhoff "Can Post-Grant Reviews Improve Patent System Design? A Twin Study of US and European Patents" (2006) GESY Discussion Paper 38; Paul H Jensen, Alfons Palangkaraya and Elisabeth Webster, above n 107; Stuart Graham, Bronwyn Hall, Dietmar Haroff and David Mowery "Post-issue Patent 'Quality Control': A comparative study of US patent re-examination and European patent opposition" (2002) NBER Working Paper Series No 8807. chapter VI. 
Therefore, the aim of this chapter is to show the diverse ways by which third parties can influence the granting procedure, by giving a general overview of the most common types of instruments used in various countries. In addition to a short description of when and how third parties can influence the granting procedure using a specific type of instrument, each type of instrument will be briefly analysed to reveal its strengths and weaknesses.

However, as third party instruments are individually developed by each country and depend on the respective patent legislation, countryspecific instruments will only be mentioned as examples for a certain type of instrument.

1 Submission of information by a third party before the patent is granted

The earliest opportunity to influence the granting process as a third party is to submit information about potential prior art to the patent office before the patent is even granted. This type of third party instrument exists in different patent regimes in several varieties: for example, as "Observation by a third party" in the European system ${ }^{145}$ or as "Notice of matters affecting validity of standard patents" in the Australian system ${ }^{146}$.

\section{(a) Rationale and objectives}

If third parties have the possibility to get access to the specifications of a patent application at the stage when the patent office examines the patentability of the claimed invention, they may be able to assist the examiner with prior art information by submitting relevant material. The objective of this type of third party instrument is to enhance the quality of patents through third parties which could have more and better information about the prior art of the relevant technology. 
(b) How does the third party influence the granting procedure with this instrument?

In this type of instrument, the influence of third parties on the granting procedure is generally limited to the submission of material. In addition to submitting material, some patent regimes allow third parties to file a statement explaining why they consider the material submitted to be relevant. ${ }^{147}$ In other regimes, explaining the prior art or submitting further information as a third party is expressly prohibited. ${ }^{148}$ However, all systems have in common that the third party does not become a party to the proceedings when using this type of third-party instrument. ${ }^{149}$ Furthermore, the third party does not have the right to insist that the examiner consider any of the material submitted. It is left to the discretion of the examiners to decide to raise an objection based on the material submitted or not. ${ }^{150}$ In other words, the third party using this type of instrument has only an indirect influence on the granting procedure.

\section{(c) Advantages and disadvantages of this type of instrument}

One advantage of this type of third-party instrument is that it gives a third party the right to provide the patent office with material regarding the patentability of a patent application, informally and typically without paying a fee. ${ }^{151}$ Furthermore, all questions of patentability can generally be addressed without limit on specific grounds (such as lack of novelty), in

For the European system, see EPC, above n 3, art 115(1); for the Australian system, see Patents Act 1990 (Cth) s 27(1).

For the United States, see 37 CFR $\S 1.99$ [R-5].

See EPC, above n 3, art 115(1), Rule 114 stated: "In proceedings before the European Patent Office, following the publication of the European patent application, any third party may, in accordance with the Implementing Regulations, present observations concerning the patentability of the invention to which the application or patent relates. That person shall not be a party to the proceedings." or United Kingdom Patent Act 1977, sec 21(2), which provides "It is hereby declared that a person does not become a party to any proceedings under this Act before the comptroller by reason only that he makes observations under this section." (emphasis added).

See, for example, United States Patent and Trademark Office Manual of Patent Examining Procedure (8th ed, 7th rev, Thomson/West, Washington, 2008) ch 1100, 1134.01 [MPEP]. In most patent systems that provide submission instruments, no fee is required for the submission of information (for example EPO, United Kingdom, and Japan). However, in the United States, a fee must be paid, see 37 CFR, $§ 1.99(b)(1)$. 
contrast to the usual proceedings for other instruments, such as opposition or revocation. ${ }^{152}$ Another advantage of this instrument is that the third party does not become a party involved in the granting procedure. ${ }^{153}$ In some patent regimes, anonymously filing the information relevant to the patent applicant is permitted. ${ }^{154}$ This may help the patent office to obtain prior art information from third parties even if they have business contacts to the applicant. Additionally, this instrument does not in general restrict the possibility to submit relevant material to a specific time period, as instruments such as opposition do. Using this instrument, relevant material can typically be submitted throughout the entire lifetime of the patent. ${ }^{155}$

On the other hand, submitting relevant material does not ensure that the examiner will carry out any further review of the patent application. It is possible that the examiner may simply include the new documents in the file without raising an objection based on the material. The submitting third party does not have the right to insist that the examiner take these documents into consideration. ${ }^{156}$

Additionally, this type of third party instrument requires the patent office to publish the patent application after the applicant files it. Only when third parties have access to patent specifications are they able to provide the patent office with relevant information on prior art. Without publication of the specification before the grant of a patent, the prior art search could only be carried out by the examiner, and relevant material known only to third parties could not be taken into consideration. Therefore, most patent systems worldwide provide for an automatic publication of the specification of an application after a certain amount of time (for example, 18 months

For example, in the European system it is possible to submit a third-party observation on the following grounds: alleged and proven invalidity of prior claims; inadmissible amendments of the claims within the scope of the original disclose (art 123(2)); nonenabling teaching (art. 83); and lack of clarity in violation of article 84, see EPC, above n 3, art 115.

See citation under n 149 .

For example, submission on an anonymous basis is permitted under the Japanese Patent Law, see Regulations under the Patent Act (Japan), art 13bis seq.

See, for example, Patents Act 1990 (Cth), s 27(1).

See, for example, MPEP, above n 150, ch 1134.01. 
after filing). ${ }^{157}$ The main objection to automatic publication in the early stages is that this would allow competitors to infringe freely with no risk of injunction until the patent is granted. ${ }^{158}$ Patent systems with automatic publication thus need to provide regulations to protect applicants against infringing acts undertaken after publication but before the grant of the patent. ${ }^{159}$

In some countries, moreover, the material filed in an observation procedure cannot be used by the same third party in a subsequent challenge of the patent such as an opposition procedure. It is still possible to file an opposition, but it must be based on new material. ${ }^{160}$

\section{(d) Result}

The submission instrument helps enhance the quality of patents because it is a simple and inexpensive way to challenge the grant of a patent on all criteria of patentability. Third parties will therefore be motivated to file relevant material, supporting the prior art search of the patent office.

On the other hand, as this third-party action only supports the patent office, its influence is limited to the submission of relevant material. The examiner is still the one who decides whether or not to take these documents into consideration. That means that third parties submitting relevant material to the patent office face the risk of forfeiting the right to this material in more powerful third-party instruments if the examiner rejects its relevance.

For example, international applications under the Patent Cooperation Treaty are automatically published 18 months after the priority date of the application, see PCT, above n 5, art 21(2)(a). Furthermore, European patent applications as well as United States patent applications are automatically published 18 months after the date of filing or, if priority has been claimed, from the date of priority, see EPC, above n3, art 93(1)(a) and 35 USC $122(\mathrm{~b})(1)(\mathrm{A})$. For a general overview of the publication dates for patents, see MPEP, above n 150, ch 901.5.

This was possible under the United States patent regime until it changed its patent law by implementing provisional rights (35 USC 154(d)(1)), see American Inventor's Protection Act 1999, Appendix L - Patents Law.

For example, in the United States the applicant has the right to obtain reasonable royalties from any person who exploits the invention before the granting of a patent, 35 USC 154(d)(1). In Australia, art 57(1) of the Patents Act (1990) enables the patentee to recover damages or an account profit. 
However, even if a third party does not want to have its own strong influence on the procedure, the material submitted to the patent office is made available to the public. This material can then be used by other third parties to file other types of third-party instruments, for example an opposition, based on these documents.

Overall, the submission instrument is an inexpensive and informal way to support the patent office with additional prior art material if a third party prefers not to assume an active role in the granting procedure.

\section{Re-examination}

Another instrument that allows a third party to exert influence on the granting procedure is the request for re-examination. This type of instrument exists in different patent regimes but it is predominantly associated with the patent system of the United States. ${ }^{161}$ The United States patent regime provides two different types of re-examination instruments: "ex parte reexamination" 162 and "inter partes re-examination". ${ }^{163}$

(a) Objective and rationale

The instrument of re-examination is an alternative to the opposition system. Its objective is to provide a forum to challenge the validity of patents outside the courts by re-examining granted patents on the basis of new prior art. ${ }^{164}$ It allows the correction of patents granted too broadly and the rejection of invalid patents. Using this instrument helps increase the overall quality of patents by correcting the errors of the patent office. ${ }^{165}$ 1990 (Cth), s 97, and in the Canadian patent regime, see Patents Act (RSC 1985, cP-4), s 48.1 . 35 USC $\S 302-\S 307$. Ibid, § $311-\S 318$. See, for example, 35 USC $\S 302$.

See Bronwyn Hall, Stuart Graham, Dietmar Harhoff "Prospects for Improving U.S. Patent quality via Postgrant Opposition" in Adam Jaffe, Josh Lerner and Scott Stern Innovation Policy and the Economy Vol 4 (The MIT Press, Cambridge, 2004) 117, 123. 
(b) How does the third party influence the granting procedure with this instrument?

The instrument of re-examination provides third parties or the patentee with the right to request further examination by the patent office on certain questions of patentability. ${ }^{166}$ The grounds for re-examination are typically strictly limited: for example, the lack of novelty or inventiveness. ${ }^{167}$

In general, re-examination can be requested at any time during the enforceability period of the patent, which means from the date of granting until the patent expires. ${ }^{168}$ Under some patent regimes, re-examination can also be carried out at the discretion of the examiner after the acceptance of a patent application. In this case, third parties have no right to request reexamination. ${ }^{169}$

In order to influence the outcome of the patent office's reexamination, third parties may submit new prior art with their request. However, under most patent regimes, the basis of re-examination is limited to certain types of prior art. ${ }^{170}$

In addition to prior art documents, third parties may also need to file an additional submission explaining the relevance of the documents. ${ }^{171}$ In some systems (for example, in the United States), third parties have the option to choose whether they want to submit a statement accompanying the prior art or not. ${ }^{172}$ If they do so, they become a party to the procedure with some extended opportunities for involvement (this is referred to as inter

An ex parte re-examination can also be requested by the patentee, which is not possible for the inter partes re-examination.

For example, Patent Act 1990 (Cth), s 98(1).

35 USC $\S 302, \S 311$.

See, for example, Patents Act 1990 (Cth), s 97.

See 35 USC $\S 302$ or Australian Patent Office Patent Manual of Practise and Procedure Vol 2, [22.4.3].

See, for example, Patent Regulation 1991 (Cth), reg 9.2(2A).

However, the requester must furnish the Commissioner with documents supporting the grounds for re-examination and must state the relevance of these documents, ibid, reg 9.2. 
partes re-examination in the United States). ${ }^{173}$ If not, the involvement of the third party in the proceedings is strictly limited (ex parte re-examination). ${ }^{174}$

As with the submission instrument, in the re-examination procedure, the examiner typically remains the final arbiter of the process, and the influence of the requesting party is strictly limited. In the re-examination procedure of the United States, the third party has the opportunity to reply only if the patentee responds to the determination of the patent office. ${ }^{175} \mathrm{In}$ the Australian system, the requester does not have the opportunity to file a statement until the Commissioner has issued his or her report. ${ }^{176}$ In this system, no other written statements are allowed. ${ }^{177}$

By contrast, the inter partes re-examination procedure allows third parties to participate fully in the proceedings. They have the right to file statements on the issues raised by the patentee or the patent office. ${ }^{178}$

\section{(c) Advantages and disadvantages of this type of instrument}

The re-examination procedure has the advantage that for a requesting third party, the standard of proof necessary to invalidate a patent is substantially lower than the standard used at trial. ${ }^{179}$ Moreover, a reexamination procedure is significantly cheaper than costly patent litigation in courts.

However, the re-examination instruments have the disadvantage that, in order to prevent abusive tactics, a threshold requirement often exists that determines whether or not the patent office will carry out a re-examination. In the United States, for example, the patent statute only allows a reexamination if there are substantial new questions of patentability. ${ }^{180}$ The

35 USC $\S 311-\S 318$.

Ibid, § 305 .

Ibid.

Patents Act 1990 (Cth), s 99.

However, under the Australian system, the Commissioner must give the patentee the opportunity to be heard before refusing the application or revoking the patent, Patent Act 1990 (Cth), ss 100A(2), 101(a).

35 USC § 314(b)(2).

See John M Carson and William J Blonigan "USA: Patents - Re-Examination" (2009) 31 EIPR N15.

180

See 35 USC $\S 303,312$. 
patent office will first determine whether the request for re-examination is based on this issue. If the patent office makes the determination that no substantial new questions of patentability have been raised, it will not carry out a re-examination. ${ }^{181}$ Moreover, this decision of whether or not the threshold has been reached is final. Both parties, the third party and the patentee, have no right to appeal.

Third parties are further limited in their ability to raise certain objections, because the grounds for re-examination are typically more limited than those for opposition or revocation. ${ }^{182}$ In addition, as the basis of re-examination is limited to certain types of prior art, other relevant evidence for the lack of novelty or inventiveness cannot be used. Finally, the prior art filed by a third party in a re-examination process generally cannot be used in a later opposition or court procedure. ${ }^{183}$

\section{(d) Result}

The re-examination instrument, at least in the inter partes variant, gives third parties more influence on the procedures of the patent office than the submission instrument. On the other hand, the influence of third parties using re-examination as an instrument is limited in almost the same manner as submission is. In both procedures, the requester provides the patent office with new prior art and has the opportunity to comment on the statements of the patentee and the patent office.

However, the odds of successfully challenging a patent in a reexamination procedure greatly depend on the type of prior art available in the field of technology of the patent. Particularly in the case of new technologies, much of the prior art may be of the non-patent variety. For

See MPEP, above n 150, 2242.

The grounds for re-examination are mostly limited to lack of novelty and lack of inventive step; see, for example, Patents Act 1990 (Cth), s 98(1). In contrast, the grounds for revocation in court proceedings under the Australian system include novelty, nonobviousness, utility, and lack of entitlement; obtaining by fraud, false suggestion, or misrepresentation; and insufficiency, ambiguity, and lack of fair basis, see Patents Act 1990(Cth), s 138 (3). from raising in a court proceeding any objection on the validity of a patent already raised in the re-examination procedure, see 35 USC $\$ 315$ (c). 
example, for inventions in computer-based fields, most prior art may actually exist in running businesses or in non-published sources, such as internet news groups. ${ }^{184}$ As such evidence is inadmissible, and as expert statements cannot be used in the re-examination procedure, this instrument may not be the best solution to correct this type of patent. Unfortunately, patents based on new technology create the most difficulties for patent offices in the examination procedure. ${ }^{185}$

As a result, the effectiveness of the re-examination instrument is highly debatable. ${ }^{186}$ Even the United States has been contemplating for years extending its existing third-party instruments with a post-grant review procedure similar to an opposition. ${ }^{187}$

Re-examination is a third-party instrument that has the potential to enhance the quality of patents without resorting to legal procedures in the courts. On the other hand, re-examination also limits the ability of third parties to raise questions on patentability other than novelty and inventiveness, and it prohibits objections based on certain types of prior art. However, whether a limited prior art base has a significant influence on the effectiveness of the re-examination procedure is questionable, as the local novelty standard, for example, also limits the prior art base. The main problem of the re-examination procedure seems to be that the patent office exerts a dominant influence on the procedure and that the influence of third parties is limited.

Re-examination is one possibility in challenging the validity of a patent at the administrative stage, as is opposition, but it cannot completely replace the judiciary in deciding questions of validity. At this stage of the process, the validity of a patent cannot be guaranteed, no matter how carefully the patent office examines the application. In all patent regimes providing administrative instruments to challenge the validity of a patent, it

See Cohen, above n 114.

See USPTO, above n 121.

See, for example, Hall, Graham and Harhoff, above n 165, 117; Shi, above n 120.

United States Patent Reform Act 2009, HR 1260, 515, 610. 
is still the function of the courts to finally determine whether or not a patent meets the requirements of the law. ${ }^{188}$

\section{Opposition}

Another inter partes administrative instrument to challenge the grant or the validity of a patent is the opposition procedure. Many patent regimes give third parties the opportunity to oppose a grant or the validity of a patent before the patent office, based on specific grounds and within a certain time period.

Two types of opposition instruments exist in current patent regimes: "pre-grant opposition", which challenges a patent application soon before it will be granted, and "post-grant opposition", which challenges an already granted patent. Some regimes, such as the European patent regime, provide only one type of opposition instrument, primarily the post-grant variant. ${ }^{189}$ Other regimes, such as the current New Zealand and the Australian patent regimes, provide both variants: a pre-grant opposition and a post-grant revocation procedure ruled on by the Commissioner. ${ }^{190}$

(a) Objective and rationale

The main objective of opposition instruments is to provide an effective but simple and fast instrument to challenge patents within the patent office, outside of the courts. The aim of the opposition instrument is to enhance the quality of patents by allowing an early correction of overly broad or invalid patents. for Australia, see McKeough, Steward and Griffith, above n 94, 404. EPC, above n 3, art 99.

Pre-grant opposition: Patents Act 1953, s 21, Patent Act 1990 (Cth), s 59, 101M; Post-grant opposition/revocation by Commissioner: Patents Act 1953, s 42, Patent Act 1990 (Cth), s 101. 
(b) How does the third party influence the granting procedure with this instrument?

(i) Pre-grant opposition

Some patent systems (for example, the current New Zealand system) provide third parties with a pre-grant opposition instrument. ${ }^{191}$ After the examiner carries out the substantive examination of the patent application and proclaims a positive result, he or she publishes the intention to grant a patent. At this point, the third party has the opportunity to join the procedure in opposition of the granting.

The right of opposition means that third parties are allowed to participate in the granting process in a fully integrated capacity. Consequently, they have the right to oppose the grant of the patent on certain grounds and to submit all evidence required.

Such opposition systems are typically bound to a certain short deadline after the acceptance of the patent application (for example, three months). ${ }^{192}$ If no opposition is filed in this period, the patent will be granted.

Filing an opposition means that the third party has the burden of proof to provide the evidence that the opposed patent application is not patentable. ${ }^{193}$ The third party must provide evidence - for example, prior art documents or statements of witnesses to demonstrate that an application lacks novelty.

Pre-grant opposition is exceptionally due to the fact that the third party has such strong influence in the granting process at such an early stage, without bearing the risk that the patent will be enforced in a parallel infringing action. One criticism of this instrument is that pre-grant oppositions could be used to slow down the granting procedure. As a result, pre-grant opposition has been abolished in most patent systems in recent decades. ${ }^{194}$ However, some countries (including Australia) have deliberately

Patents Act 1953, s 21.

See, for example, Patents Act 1953, s 21(2).

See McKeough, Steward and Griffith, above n 94, 322.

For example, the United Kingdom shifted its pre-grant opposition to a post-grant opposition system in 1970, see Her Majesty's Stationery Office (1970) The British Patent System: Report of the Committee to Examine the Patent System and Patent Law (the Banks Report); 
decided in favour of pre-grant opposition and still provide third parties with the right to oppose a patent before it is granted based on the lack of novelty or inventiveness. ${ }^{195}$

(ii) Post grant opposition/ revocation by Commissioner

The more common version of opposition is post-grant opposition. ${ }^{196}$ The post-grant opposition instrument gives third parties the right to challenge the validity of a patent within a certain period of time after the patent has been granted. ${ }^{197}$

In some systems (for example, in New Zealand), the instrument "revocation by Commissioner" substitutes for post-grant opposition; it is generally similar to the post-grant opposition instrument found in the European Union, and is often referred to as "delayed opposition" or "postgrant opposition". ${ }^{198}$

In post-grant opposition, as in pre-grant opposition, the third party becomes a full party to the procedure, enjoying the opportunity to submit statements at any time. The main difference between pre-grant and postgrant opposition is that the opponent in post-grant proceedings usually has more grounds available to oppose the patent.

(c) Advantages and disadvantages of this type of instrument

In order to avoid overly broad or invalid patents, it is useful to provide an additional layer of review correcting undesirable patents outside the

Japan changed it in the mid-1990s, see Keith E Markus and Christine McDaniel "Impacts of the Japanese patent system on productivity growth" (1999) 11 Japan \& World Econ 557. See Advisory Council on Industrial Property "Review of Enforcement of Industrial Property Rights" (Commonwealth of Australia, 1999); Intellectual Property and Competition Review Committee "Review of intellectual property legislation under the Competition Principles Agreement" (Commonwealth of Australia, 2000). For example, in the European system, see EPC, above n 3, art 99. The United States system has no opposition procedure but plans to provide such a review system, see Patent Reform Act 2009 HR 1260. On the other hand, Japan abolished its post-grant opposition in 2004 and replaced it with an invalidation appeal procedure. European patent, see EPC, above n 3, art 99(1); or within 12 months after the sealing of a patent, Patents Act 1953, s 42(1). 
courts. The opposition instrument allows an early administrative review that is generally simpler, faster, and cheaper than proceedings by a judicial body. ${ }^{199}$ As an administrative procedure, an opposition can typically be filed by anybody, using a standard form. Furthermore, the standards of proof applicable in the patent office are generally lower than in the courts, helping to simplify the procedure and to save money. In addition, the examiners making the decision in an opposition procedure have technical expertise that judges may lack. Under some systems, the opposition procedure is held before independent hearing officers $;{ }^{200}$ in other systems, a former examiner can also be a member of the opposition division. ${ }^{201}$

Opposition's principal advantage over the re-examination procedure is that in opposition procedures, being more adversarial proceedings, all kinds of evidence are allowed - for example, the testimony of inventors and experts. ${ }^{202}$

On the other hand, the opposition procedure is not free and can be time-consuming. The patent office needs enough examiners to review the examination procedure and the arguments in the statements of the patentee and the opponent in an adequate amount of time. However, this disadvantage is not terribly serious, as only a small percentage of all patents are ever opposed. ${ }^{203}$

The main criticism of opposition procedures lies in the fact that this additional review can substantially delay the entire patent-granting process. ${ }^{204}$ If more than one opponent opposes a patent on several grounds with different prior art documents, an opposition procedure can last for

For the relationship between opposition and revocation by courts, see Jan Brinkhof "The Revocation of European Patents" (1996) 27 IRIPCL, 225.

For example, in the New Zealand system, see IPONZ www.iponz.govt.nz; in the United Kingdom system, see Intellectual Property Office www.ipo.gov.uk (both accessed 14 March 2010).

For example, in the European system, see European Patent Office Guidelines for Examination in the European Patent Office (EPO, Munich, 2009) part D, ch II, 2.1.

Robert Merges, above n 74, 611.

In 2007, the opposition rate at the European Patent Office was 6\%; at the German Patent Office, 4.6\%; and at the Korean Patent Office, 1.3\%, see WIPO Statistics Database, www.wipo.int. The rate is calculated based on the number of oppositions filed and patents granted in 2007.

Patents Bill 2008 (Explanatory note), 54. 
years. ${ }^{205}$ Moreover, as most countries that provide an opposition procedure also allow an appeal of the decision of the opposition body, the process to reach a final decision on the validity of a patent could last longer than patent litigation proceedings in the courts. ${ }^{206}$

As a result, pre-grant oppositions have been rejected in most patent systems worldwide, as they were causing delays and financial burdens. ${ }^{207}$ For example, the United States rejected its pre-grant opposition procedure because opponents could delay the grant of a patent by repeated citations of prior art. ${ }^{208}$

\section{(d) Result}

Opposition systems help increase confidence in patentability and validity because they allow challenges to patent applications or to granted patents. This additional review may have the effect that fewer overly broad or invalid patents remain in the market, thereby increasing the overall quality of patents. However, this additional process may also delay the grant of a patent, resulting in a negative effect on patent values and on innovation.

Overall, opposition procedures are a good solution to review patents at an administrative stage, because they are generally simpler, less expensive, and less time consuming than court proceedings. ${ }^{209}$

For example, seventeen oppositions have been filed from different groups in the opposition procedure against Harvard's OncoMouse patent. The complete opposition and appeal procedure lasted for 9 years, see file to EP 0169672 at European patent register, https://register.epoline.org.

In opposition procedures before the European Patent Office, the average duration of both procedures combined is 3.6 years, longer than the average duration of 2.8 years for patent litigation proceedings by the national courts of the $27 \mathrm{EU}$ states, see European Patent Office "European Commission Pharmaceutical Sector Inquiry: Preliminary Report 28 November 2008 - Comments from EPO”, www.ec.europa.eu (accessed 20 January 2010). See Janis, above n 99, 33

Senator Fong in United States Congress (1974) 120 Congressional Record 41, 145. A good overview of the advantages and disadvantages of an opposition procedure is presented in Jonathan Levin and Richard Levin "Patent Oppositions" (2002) SIEPR Discussion Paper No. 01-29. 


\section{$4 \quad$ Challenging the validity of patents before the Courts}

All of the types of third-party instruments described above are administrative procedures of the patent office. Alongside these administrative procedures, most patent systems also provide possibilities to challenge the validity of a patent before a court. For example, New Zealand provides a revocation by the courts; other systems have nullity or invalidity actions. $^{210}$

Challenging the validity of patents before a court has the disadvantage that the standard of proof is generally higher than in an administrative procedure. The process is also more expensive and time-consuming. ${ }^{211}$ The high cost of patent litigation poses a heavy burden on patentees as well as on third parties. ${ }^{212}$

Prolonged validity actions can be problematic in time-sensitive areas of technology: for example, for computer-related inventions. Moreover, unlike the judicial branch, the patent office has resources and technical knowledge, which make it a "natural champion in assessing patent validity issues" ${ }^{213}$; because validity questions often involve technical questions, the technically skilled examiners of the Patent Office may be better equipped to answer them than judges would be. ${ }^{214}$ On the other hand, Court-based proceedings are necessary because a judicial body and not an administrative

See Patents Act 1953, s 41; in New Zealand, the applicant can choose whether he or she wants to challenge a patent before the Commissioner in an administrative procedure or before the courts. In Germany, a patent can be challenged in a nullity action without pending infringement procedures, see Patentgesetz 1980 (Germany), s 81(1). For the relationship between opposition and revocation, see Jan Brinkhof, above n 199, 225.

212 For the United States, the American Intellectual Property Law Association estimated a total litigation cost of an average of 2.5 to 4.9 million US dollars per party, see AIPLA Report of the Economic Survey (AIPLA, Washington, 2009). Unfortunately, such a survey of patent litigation costs in New Zealand is not available. However, the World Bank ranks New Zealand at $11^{\text {th }}$ position in the world for efficiency of contract enforcement, with legal costs on average $22 \%$ of the claim value. In contrast, the United States is ranked at $6^{\text {th }}$ position, with legal costs at $9.4 \%$ of the claim value. See World Bank Doing Business Report (Palgrave Macmillan, 2009). For an overview of the civil litigation cost regimes in different jurisdictions, including New Zealand, see Judiciary of England and Wales Civil Litigation Cost Review: Preliminary Report Vol. 2 (2009, London). 
body should finally decide whether or not the requirements of the law have been met. $^{215}$

Consequently, the best solution for reviewing patents should be based on a two-tiered system in which the determination of patent validity is divided between the patent office and the courts.

\section{What Types of Review Systems Are Available?}

As detailed above, all types of instruments a third party can use to exert influence in the patent-granting procedure have specific advantages and disadvantages. None of the analysed procedures (submission, reexamination, and opposition) provides an all-in-one solution. As a result, the question of which types of third-party instruments and which procedures allowing third parties to take part in the patent-granting process would constitute the best solution for New Zealand cannot be answered simply.

One point to keep in mind is that the design of a reviewing approach for patents or applications based on the knowledge and experience of third parties is not possible without an awareness of the overarching structure of the patent system. Each alteration in the system typically necessitates further adjustments in order to keep the system in balance. Most patent systems that allow third parties to influence the grant of a patent thus provide a reviewing system consisting of a combination of different types of third-party instruments at different stages of the granting procedure.

As the next step on the way to finding the best reviewing system for New Zealand, it would therefore be helpful to define the combinations of third-party instruments already in existence. Each combination of thirdparty instruments creates a specific type of patent-reviewing system with different weighting of the influence of third parties. These types of reviewing systems are not specified, but are instead classified freely according to the quantity and quality of influence that third parties can have in the granting procedure. 


\section{$1 \quad$ Inquisitorial review systems}

In this type of reviewing system, the patent office has the primary responsibility to separate inventions that should obtain patent protection from applications that should not, based on extensive examination by qualified examiners. Inquisitorial reviewing means that third parties have no influence or only strictly limited influence in the granting procedure. Patent regimes belonging to this category of review system are, for example, Japan and the United States.

\section{(a) Characteristics of such a system}

The main characteristic of an inquisitorial reviewing system is the low level of influence of third parties on the granting procedure. The first possible time when third parties are able to exert a direct and unlimited influence is when they bring patents with doubtful validity before the court or when they challenge the validity of a patent in an infringement action.

At the administrative stage, the role of third parties is mostly limited to supporting the patent office, for example, by submitting relevant prior art information. ${ }^{216}$ Even when third parties are allowed to file their own statements or responses, it is only permitted to a certain extent. ${ }^{217}$

The patent office in such a system has the power to decide whether or not it will raise objections based on prior art material submitted by third parties. As third parties are in general not even parties to the procedure, they have no right to insist if the patent office decides to ignore submitted documents. ${ }^{218}$

In addition, even though third parties may have the right to submit evidence that an application is not patentable, inquisitorial systems typically limit the types of evidence admissible in the procedure.

See, for example 35 USC $\S 302$.

Ibid.

See, for example, MPEP, above n 150, ch 1134.01. 
(b) Third-party instruments of such a system

In the inquisitorial review system, the typical third-party instrument at the administrative stage is re-examination. In some cases, submission of information will also be allowed, but without extensive statements from the third party. However, the challenge of the validity of a patent before the court is also allowed, for example, as a defence in infringement actions.

(c) Analysing such an approach

The inquisitorial review system has the advantage that the review of a patent is based on the same standards as the examination procedure. This means that the patent office repeats the examination procedure using new information submitted by the third party. In such a system, third parties cannot use the reviewing instruments to extend the granting procedure as a way of harassing the patentee, because their influence is strictly limited.

However, the inquisitorial review approach can only be effective if the patent office has enough resources to carry out an in-depth re-examination. If the re-examination procedure is carried out under the same time pressure as the regular examination - perhaps even by the same examiner - the errors of the patent office may not be corrected. In addition, as most evidence cannot be used in re-examination procedures and the grounds of reexamination are limited, only a small amount of undesirable patents will be rejected.

\section{Adversarial review system}

In this type of review system, the third parties are largely responsible for separating patents that should be granted from those that should not. Although the patent office carries out the examination and is responsible for granting the patent, its decision on whether a patent should be revoked is based on evidence submitted by third parties and on the submissions of both parties representing their perspectives of the case. Therefore, the influence of third parties on this decision is quite strong. The European Union patent system utilizes the adversarial type of review system. 
(a) Characteristics of such a system

In the adversarial system, the third party can fully participate in the procedure. Both the patentee and the third party are allowed to submit statements in each stage of the proceedings and can discuss their points of view in an oral hearing. Typically, all kinds of evidence are allowed in challenging the validity of a patent. Before the grant of a patent, third parties are allowed to submit relevant information, as long as they state why the material is relevant to the hearing. However, in most adversarial review systems, this strong influence of third parties is allowed primarily after the grant of a patent.

(b) Third-party instruments of such a system

The typical third-party instrument of adversarial review systems is opposition. Submissions are also allowed, as well as statements explaining the filed material.

(c) Analysing such an approach

The adversarial review system has the advantage that the knowledge and experience of third parties can be promptly used, resolving erroneous decisions of the patent office at an early stage. Third parties not only provide the patent office with important information on relevant prior art, but also introduce new points of view regarding the patentability of inventions into the procedure. As more types of evidence become available, more patents in new technological fields can be reviewed. Additionally, studies show that even the patentees benefit from opposition procedures, because the system removes uncertainty and increases the value of patents. ${ }^{219}$ 
However, the strong influence of third parties also has the effect of delaying the granting procedure. In its worst form, third parties could use opposition to harass their competitors.

\section{$3 \quad$ Hybrid review system}

It is also possible to implement a review system that uses aspects of both approaches, combining the inquisitorial and the adversarial instruments. This means that third parties have the same influence on different stages of the procedure, pre-grant and post-grant, but also that the influence is limited in its depth and intensity. The patent regimes in New Zealand and Australia utilize hybrid reviewing systems.

(a) Characteristics of such a system

In a hybrid reviewing system, third parties have different procedures available at different stages of the granting procedure. For example, thirdparty influence is limited before the patent is granted, but after the grant, the third party is allowed to fully participate in the proceedings. These systems typically provide pre-grant instruments that limit the influence of a third party by the time schedule and by the admissible reasons to challenge the grant of an application. However, the post-grant instruments give third parties the right to challenge the grant of patents on broader grounds.

(b) Third-party instruments of such a system

Hybrid systems normally provide combinations either of reexamination and opposition instruments, or of limited pre-grant opposition and unlimited post-grant opposition instruments.

\section{(c) Analysing such an approach}

Hybrid review systems are based on the concept that both approaches, inquisitorial and adversarial, have their advantages and disadvantages. As the resources of the patent offices in small countries are more limited, it seems advantageous to give third parties an early and strong influence on 
the granting procedure in order to support the patent office. However, using the knowledge and experience of third parties before the grant of a patent can be disadvantageous, as it can delay the grant procedure. On the basis of these arguments, a hybrid review system has been developed that attempts to find a balance between both positions.

\section{SYSTEMS IN BALANCE - INTERMEDIATE RESULT}

As previously explained, a patent system is in balance if it is possible to avoid granting overly broad or invalid patents. New Zealand should therefore aim for a patent system that is able to keep the balance between the public interest and the interests of the monopoly holder. The higher the quality of New Zealand patents, the higher the benefits for all concerned.

In order to reach this goal, it has been illustrated that, in addition to streamlining the examination procedure by implementing stricter standards, third parties should also be allowed to contribute their knowledge and experience to the procedure. The combination of stricter examination procedures and providing third-party instruments would appear to be a wellbalanced solution to enhance the overall quality of patents without overburdening the existing resources. Stricter examination standards help deny monopoly rights for inventions that should not be granted, and thirdparty support helps the patent office review the patentability of inventions. Such a combination would result in fewer undesirable patents being granted or surviving in the market, increasing confidence in the patentability and the value of New Zealand patents.

In order to maintain the balance, New Zealand should have stricter examination standards in combination with a review system for its patents that utilizes the knowledge and experience of third parties.

The framework of this dissertation does not allow a complete and detailed review of the current patent system with regard to both aspects. However, it is impossible to review New Zealand's current third-party instruments and its patent review system without analysing its examination standards. Therefore, the focus will be on the development of a review 
system for New Zealand based on third-party instruments, taking the examination standards into account as long it is useful in the context.

In the review of third-party instruments, it has been shown above that the different national patent regimes provide different procedures for third parties to influence the granting procedure. Depending on the third-party instruments used, different levels of influence result. These procedures are parts of patent review systems favouring an inquisitorial, an adversarial, or a hybrid approach. Each instrument and each review system has its advantages and disadvantages: it cannot be said that one of those systems is definitely superior. These national reviewing systems have been developed under various circumstances in different countries. It is impossible for a country to simply adopt an existing review system of another patent regime without making adjustments to it with respect to the specific local circumstances and needs of the adopting country.

New Zealand already has a review system including third-party instruments in place. Despite this, New Zealand faces the problem that the quality of its patents is not as high as it could be. As simply adopting another patent review system is not useful, it is necessary determine why the current New Zealand system is not effective at enhancing the quality of patents and how it can be revised to reach this goal.

In order to answer these questions, it is first necessary to show the framework in which New Zealand's current reviewing system was established. New Zealand's patent system is, in its way, unique in the world, with its outdated patent litigation and particular problematic issues. The next section of this dissertation begins with an examination of how the current New Zealand patent system works, identifying which particular issues need to be considered with an eye to a revision of the system.

Next, this dissertation will examine in detail how the current New Zealand patent review system is designed, including its third party instruments. In addition, the reform efforts of the past few years will be explained. In this context, there will be an exploration of whether the Patents Bill 2008 would result in a better system for New Zealand. Finally, there will be possible suggestions of if and how the New Zealand review 
system (including its third party instruments) should be revised to find an optimal solution for the specific needs of the country.

\section{NEW ZEALAND'S PATENT SYSTEM AT WORK}

\section{A Scope of the Patent System in New Zealand}

In order to find out which patent review system is the best for New Zealand, it is first necessary to define the particular issues concerning the current patent system in New Zealand.

\section{$1 \quad$ Patent policy in New Zealand}

Similar to the policy of most patent regimes worldwide, the patent policy of New Zealand has the fundamental purpose of promoting innovation for the benefit of society. ${ }^{220}$

Although the current New Zealand Patents Act 1953 includes no preamble describing its purposes, it can be assumed that one of its purposes is to ensure that New Zealand should profit as much as possible from its patent system. To this end, the explanatory note to the New Zealand Patent Bill 2008 states: $:^{221}$

\footnotetext{
The provision of this exclusive right is intended to provide inventors with an opportunity to make a return on their investment in innovation by preventing others from copying the invention. This provides an incentive for innovation and its dissemination that might not otherwise occur. The grant of patent rights also provides an incentive for foreign innovators to transfer their innovations to New Zealand. It is the benefits to society of this incentive effect that provide the main justification for the patent system.
}

According to the Bill, the New Zealand patent policy system also has the objective of stimulating the economy by providing protection against imitators and by offering an incentive to transfer technology to New Zealand. 
The Ministry of Commerce has summarized the patent policy of New Zealand as follows: ${ }^{222}$

[It aims] ... to ensure that New Zealand is:

(1) no longer isolated from international developments;

(2) internationally competitive; and

(3) encouraging investment and innovation.

As demonstrated above, the New Zealand patent regime should also be able to balance the interests of all concerned, and its patent law should comply with the international obligations of New Zealand. In accordance, the Explanatory Note of the Patents Bill 2008 states: ${ }^{223}$

Statement of public policy objective(s)

To provide an efficient and effective patent system that promotes innovation and economic growth while providing an appropriate balance between the interests of innovators and the interests of society as a whole and that complies with New Zealand's international obligations.

\section{Influences from the outside on New Zealand's patent policy}

The New Zealand patent policy has been in part formed by influences from the outside. In order to understand some particularities of New Zealand patent law, these aspects need to be taken into account.

\section{(a) Adopting United Kingdom statutes}

The patent regime in New Zealand is derived from the system of the United Kingdom: namely, the current New Zealand Patent Act 1953 is based on the 1949 United Kingdom Patents Act. As with a number of other statutes, New Zealand adopted the United Kingdom Patent Act without taking into consideration whether it was appropriate to the particular needs of New Zealand. ${ }^{224}$ Specifically, the economic situation, which should be a 
determining factor for the design of a country's patent law, is not at all the same in the two countries. Furthermore, although the United Kingdom fundamentally revised its Patent Act in $1977^{225}$, New Zealand has adhered to the old United Kingdom law. Therefore, as explained above, the patent law of New Zealand is outdated and is overdue for reform.

\section{(b) International obligations of New Zealand}

New Zealand is a member of a number of international agreements that set intellectual property standards. Several amendments to the existing Patents Act 1953 were based on New Zealand's obligation to implement international treaties such as the Trade Related Aspects of Intellectual Property Rights Agreement (TRIPs). ${ }^{226}$ In addition, in order to no longer be isolated from international development, policy makers worldwide have implemented harmonisation reforms in patent law. These are principally based on the treaties of the World Intellectual Property Organisation (WIPO). In this regard, the Law Commission Intellectual Property of New Zealand states: ${ }^{227}$

The international context is particularly important in intellectual property. Ideas and their exploitation are not constrained by national boundaries but, in absence of international mechanisms, intellectual property rights can only be national. The need for international cooperation and reciprocity to provide a workable system of intellectual property was recognised more than a century ago.

Some of the relevant international developments and their influence on patent law in New Zealand will be discussed in more detail below. Zealand according to the obligations imposed by the TRIPs Agreement, first by restricting the grounds upon which an invention can be excluded from patentability; second, by increasing the term of a patent from 16 to 20 years; third, by limiting the circumstances in which a compulsory license may be granted; by also limiting the circumstances in which the Crown can utilise patented inventions; and by providing for the reversal of the burden of proof in cases of the alleged infringement of a process patent, see Kenneth B. Poplewell "The TRIPs Agreement: Implementation and Enforcement" (APEC Industrial Property 
(c) Harmonisation with important trading partners

As New Zealand's economy strongly depends on trade, the patent policy should attempt to coordinate New Zealand's patent law with the laws of its important trading partners. A discussion paper of the Ministry of Economic Development from 2006 states that any legislative change must not only be appropriate to New Zealand's circumstances but should also be "aligned with those of our leading trade partners [to help in] creating an environment conducive to foreign and domestic business investment". ${ }^{228}$ Some of the bilateral agreements with important trading partners and their influence on New Zealand's patent law will discussed in more detail below.

\section{$3 \quad$ Particular issues for New Zealand}

In order to discuss policy issues it is necessary to acknowledge some specific features of New Zealand: its size, geographical position, topography, and inherited economic specialisation. ${ }^{229}$. It is useful to have these particularities and their influence on the design of patent law in mind, as they have an influence on the policy framework of New Zealand.

(a) New Zealand as a small economy

First, New Zealand, as a small economy, has only a small domestic market that limits the ability of businesses to grow to a size that would make them internationally competitive. Second, New Zealand's remoteness from major markets and knowledge centres can limit its international connectivity, which consequently slows down harmonisation processes. Moreover, New Zealand's economy is still shaped by agriculture, fishing, and foresting, and it has a strong dependence on overseas trading partners. ${ }^{230}$ Auckland, 2006) viii citing "International Trade Treaties" March 2006, para 6. NEW ZEALAND (OECDPublishing, Paris, 2007) www.sourceoecd.org (accessed 5 November 2009). 
(b) New Zealand as net importer

New Zealand is a net importer, and it should be noted that most of the patents granted in New Zealand originate overseas and belong to nonresidents. ${ }^{231}$ Therefore, the harmonisation of patent law with important trading partners is a very important issue. The Ministry of Economic Development states that New Zealand patent policy should encourage the transfer of technology to New Zealand in order to give New Zealand's businesses access to the technology and expertise they need to be competitive on the international market. ${ }^{232}$ They further state that any legislative changes must not only be appropriate to New Zealand's circumstances but also be "aligned with those of our leading trade partners [to help in] creating an environment conducive to foreign and domestic business investment" ${ }^{\prime 233}$. In general, the patent law of New Zealand should not stray too far from international patent standards. ${ }^{234}$

\section{(c) Māori issues}

Owning to its history, New Zealand places particular importance on its policy to involve Māori in matters that may be relevant to them. With respect to patent law, these issues are, in particular, the protection of traditional knowledge and of indigenous plants and animals. ${ }^{235}$ Under the Patents Act 1953, cultural issues can only be examined under the morality clause in section 17(1) of the Act, which gives the Commissioner the power to refuse a patent application if the use of the invention would be contrary to

Intellectual Property Office of New Zealand "Report of the Commissioner of Patents, Trade Marks and Designs to the Minister of Commerce for the years ended 30 June 2008" (IPONZ, Wellington, 2008).

Boundaries to Patentability, above n 14.

Sumpter, above n 228, viii citing "International Trade Treaties" March 2006, para 6.

Boundaries of Patentability above n 14, 6 .

The failure to protect the traditional knowledge of the Māori and indigenous plants and animals under intellectual property law is one issue of the Wai 262 claim before the Waitangi Tribunal. See Te Hunga Roia Maori o Aotearoa (Maori Law Society Inc.) "Submission on the Patents Bill before the Commerce Select Committee 2 July 2009" www.maorilawsociety.co.nz (accessed 15 March 2010). 
morality. However, this morality exclusion presents difficulties, because the examiner must make morality judgements. ${ }^{236}$

\section{B Objections Against the Current New Zealand Examination Procedure by the IPONZ \\ $1 \quad$ Resources of the IPONZ}

As previously described, the resources of the IPONZ are limited. It already has difficulty to provide a sufficient number of qualified and experienced examiners, as patent applications have become more complex in recent years. ${ }^{237}$ Furthermore, due to developments in the new technology market, more and more applications are being filed outside of traditional technological fields. This means that even more highly specialised examiners are needed in order to carry out high quality examinations. Due to its size, however, New Zealand has only a small number of experts available. $^{238}$

\section{Automatic examination}

New Zealand's patent law provides for an automatic examination. Once the applicant has filed a complete application, the Commissioner will automatically refer it to one of the IPONZ examiners. The examiner will determine if the patent application complies with the formal and legal requirements of the Act and with any relevant regulations. ${ }^{239}$ An explicit request for examination by the applicant is only required if it is an advanced one (for example, because an infringement of the rights is likely to occur, rule 38$).^{240}$ Marks and Designs to the Minister of Commerce for the years ended 30 June 2008", above n 231, 3 .

Hon Gault "Recent Experience of Intellectual Property Law Reform" in The Context for Reform, above n 16, 21, 23.

Patents Act 1953, s 12(1).

Patent Regulation 1954, r 38 
Another particularity in the process is that the technical examination of a New Zealand application is performed without any further fees. For the examination procedure, this means that an examiner generally examines all patent applications in the order in which they are filed, without prioritisation or organisation of examination procedures according to the type of patent application. ${ }^{241}$

\section{$3 \quad$ Standard of examination}

Under current New Zealand patent law, the purpose of the examination is to decide whether an application meets all requirements for the grant of a patent: specifically, whether the subject matter is patentable and whether the invention is novel or not already claimed. As stated above, the standards of examination are lower in New Zealand than in other countries. The main sources of criticism are the following aspects:

\section{(a) Subject matter}

With respect to subject matter, the role of the examiner is to carry out a screening process in order to eliminate applications that cannot be considered inventions by a reasonable standard.

In New Zealand, a patent can only be granted if the application includes a patentable "invention" as defined in section 2(1) Patents Act 1953. ${ }^{242}$ Patents can only be granted for inventions that are a "manner of new manufacture". Unfortunately, the phrase "manner of new manufacture" provides no clear definition of what is required for an invention to be patentable or which inventions are to be excluded from patentability. As a result, this definition has been the subject of a great deal of jurisdictional attention. The courts have decided to exclude some subject matters from 
patentability, such as mere discoveries, mathematical algorithms, mere plans or schemes, and methods of medical treatment. ${ }^{243}$

The landmark Australian decision National Research Development Corporation v Commissioner of Patents ${ }^{244}$ clarifies what is meant by the term "manner of new manufacture". Specifically, as this definition incorporates section 6 of the Statute of Monopolies 1623, the subject matter of a claim needs to meet the threshold requirements imposed by the principles of patent law. ${ }^{245}$ The test posed by the High Court of Australia has been adopted by New Zealand in the landmark decision Wellcome Foundation Ltd $v$ Commissioner of Patents. ${ }^{246}$ Since Wellcome, several decisions on the issue of the patentability of specific subject matters have been written. For example, in Pharmaceutical Management Agency Ltd v Commissioner of Patents, ${ }^{247}$ the Court of Appeal held that new uses of known medical treatments are patentable as "Swiss claims". ${ }^{248}$ However, in Pfizer Inc $v$ Commissioner of Patents, ${ }^{249}$ the Court of Appeal stated that methods of medical treatments are generally not patentable.

In addition, the Patents Act 1953 provides a statutory exception to patentability in section 17, stating that the Commissioner may refuse an application if the use of the invention is contrary to morality.

The Commissioner also has the right to refuse applications for patents that appear to be entirely lacking a patentable subject matter. However, as "the question of the subject matter is one of the most uncertain issues in patent cases", ${ }^{250}$ the New Zealand patent law allows refusal in the

Generally, see Ian Finch (ed), above n 10, 20. The Court of Appeal of New Zealand confirmed general prohibition of patents on medical treatment in Pfizer Inc v Commissioner of Patents, above $\mathrm{n} 11$ following Wellcome Foundation v Commissioner of Patents [1983] NZLR 385 (CA), Cooke, McMullin and Somers JJ [Wellcome].

$N R D C$, above n 80 .

Statute of Monopolies 1623, above n 38.

Wellcome, above $\mathrm{n} 243$.

Pharmaceutical Management Agency Ltd v Commissioner of Patents [2000] 2 NZLR 529 [Pharmac].

Ibid, Gault J.

Pfizer, above n 11.

Commission to Inquire into and Report upon the Law of Patents, Design and Trade-Marks, above n 122, 26 . 
examination stage on the ground of lack of a patentable subject matter only in the clearest cases. ${ }^{251}$

Critics say that New Zealand's patent legislation should provide a clear definition of patentable inventions to ensure that the Patent Office and the courts have an appropriate tool to decide whether an invention is patentable or not. ${ }^{252}$ The advantage of a clear definition of invention is that uncertainties over whether a specific subject matter is patentable potentially contrary to the goal of encouraging innovation - can thus be reduced. ${ }^{253}$ Furthermore, if the legislation provides clear exclusions from patentability, the examiner would be able to refuse an application in the examination stage without the need for interpretation of the Act by the courts. Otherwise, there is the potential that different Assistant Commissioners would come to different conclusions for similar cases. For example, in Abbott Laboratories, Assistant Commissioner Popplewell held that a dosage regime is a method of medical treatment and therefore not patentable. ${ }^{254}$ In Merck \& Co Inc v Arrow Pharmaceuticals, however, Assistent Commissioner Hazlewood held that Swiss claims for dosage regimes are patentable. ${ }^{255}$ In Genetech Inc, Assistant Commissioner Popplewell contradicted his earlier opinion and held that such an application is patentable. ${ }^{256}$ Consequently, many feel that the IPONZ is not the place to decide whether or not a specific subject matter should be patentable. ${ }^{257}$

The lack of a distinct definition of an invention in New Zealand patent law is the subject of long debates that can only be mentioned but not entered into. However, most judges and scholars argue that issues of patentability should be left to Parliament. See Wellcome, above n 243, 398 Cooke J.

See Hammond J in Pfizer, above n 11, para 128; Susy Frankel "A Patentable Invention: Will Current Proposed Law Reform Clarify Patentable Subject Matter?” (2005) 11 NZBLQ 350.

Susy Frankel "Lord Cooke and Patents: The Scope of 'Invention"” (2008) 39 VUWLR 73, 83.

Patent Application No 510328, Abbott Laboratories (9 June 2003) Asst Commr Popplewell.

Patent Application No 501807, Merck \& Co Inc v Arrow Pharmaceuticals (NZ) Ltd (31 January 2006) Asst Commr Hazlewood. 


\section{(b) Prior art base}

A monopoly such as a patent should only be granted if the invention is new or novel. New Zealand is one of only a few countries to follow patent law based on a local novelty standard instead of an absolute novelty standard. Under the current Patent Act, the prior art base used for the examination of the novelty of a patent application is limited to documents published in New Zealand. ${ }^{258}$ This means that the patent office usually only examines patent specifications published in New Zealand and easily accessible overseas specifications. Overseas publications that are not published in New Zealand cannot be used to challenge the validity of a New Zealand patent. ${ }^{259}$ This creates both advantages and disadvantages for New Zealand.

The aim of a local novelty standard is to promote local products and industry. As publications of inventions outside New Zealand cannot be considered as anticipated claims, local novelty represents an advantage for local inventors.

However, the local novelty standard also allows people to obtain patents in New Zealand without having any creative input. For example, it is possible for importers to obtain patents for inventions by simply importing them to New Zealand. ${ }^{260}$ In a time of international trade and communication, this standard may be outdated. For instance, the local novelty standard may also enable patents to be granted in New Zealand that would usually not be granted elsewhere, and patents may have a much wider scope than other countries would allow. ${ }^{261} \mathrm{~A}$ further particularity is that most patent applications in New Zealand are based on overseas patents and are owned by non-residents. ${ }^{262}$ Using the local novelty standard may therefore result in more weak patents instead of promoting New Zealand's economy and local inventors.

Patents Act 1953, ss 13 and 2(1). Ibid, ss 21(1)(b), 41(1)(e) and 42(1). See Sherman v Merck \& Co Inc (11 April 2001) HC WN, AP 184/00, McGechan J. Hon David Parker, first reading, above n 12, 2887. See Patents Bill 2008 (Explanatory note), 54. 
(c) Examination for obviousness

Another peculiarity of the current New Zealand patent law regime is that the examiner has no right to examine the patent application on the ground of obviousness. Before the grant, obviousness can only be brought forth as an issue by a third party in a separate opposition procedure. ${ }^{263}$ As a result, New Zealand patents may protect inventions that would be ineligible for patent protection in other countries due to obviousness. ${ }^{264}$

(d) Benefit of doubt

If the patentability of an invention is in dispute, the New Zealand case law provides the applicant with the benefit of doubt. ${ }^{265}$ This means that the application should be allowed to proceed and will not be refused "unless on no reasonable view can it be regarded as meeting the requirements of the Act”266, as the Court of Appeal in Pharmaceutical Management Agency Ltd (Pharmac) v The Commissioner of Patents stated. Accordingly, in Swift \& Co, Lord Parker stated, regarding the function of the Commissioner under the equivalent United Kingdom law: ${ }^{267}$

$[\mathrm{T}]$ he function ... is not to decide finally whether an alleged manner of new manufacture is actually patentable. Rather their function is to refuse to allow applications to proceed which on no reasonable view could be said to be within the ambit of the Act. It is true that ... there are no express words to this effect, but it seems to me that looking at the scheme of the legislation as a whole that must be the position.

(Emphasis added)

Many other patent regimes worldwide have in the meantime moved away from this 'benefit of doubt' approach, adopting the more rigorous 'balance of probabilities' test as the standard of proof, including the United Australia Commissioner of Patents v Microcell Ltd (1959 1A IPR 52. 
Kingdom with the Patents Act 1977 and Australia with the Patents Amendment Act 2001. ${ }^{268}$

The rationale for the benefit-of-doubt approach is that in cases of doubtful validity, it is not the patent office who should challenge the doubtful validity of a patent during the examination stage, but rather a potential user. Davison CJ stated in this regard: ${ }^{269}$

\begin{abstract}
The proceedings are not intended to finally determine questions of validity of a patent if granted. Their purpose is to avoid the registration of patents that are clearly defective. If a patent is granted the opponent will still be entitled to apply to the Court for revocation or to seek revocation by counterclaim in an infringement action.
\end{abstract}

Consequently, examiners of the Commissioner of the IPONZ cannot refuse patent applications even in cases in which they are not sure that the patent granted is valid. The system therefore depends on third parties to challenge the validity of patents in order to remove such patents from the market. Without such a challenge, even invalid patents lacking an inventive step will survive. Consequently, most other countries have amended their standard of examination away from the benefit of doubt, shifting the burden of proof back to the patent offices. ${ }^{270}$

\title{
$4 \quad$ No automatic publication
}

Until the acceptance of the complete specification is advertised, its details are strictly confidential under the New Zealand patent law. ${ }^{271}$ Only some basic information is published in advance, such as the data of the applicant and the inventor, the title of the application, its number, its classification, and the filling date. This ensures that a third party cannot inspect the specification before its acceptance is published. The examination for Successful Patenting of Inventions and Innovations" Australasian Biotechnology, Vol. 12 No. 2, 2002, 37. [Beecham]. 
report is not open for public inspection unless allowed by a court order, section 91(2) of the Act.

A further issue is that the current Patents Act 1953 provides no time limit for the publication of an application. Under current law, an application is published at acceptance, which in New Zealand generally takes two to four years after the initial application is made. ${ }^{272}$

As a result, at present, the specification is not available to the public until it has gone through the entire examination procedure. It may take years before a third party is aware of the complete scope of the patent. Consequently, the examiner may undertake unnecessary work: a third party may challenge the application with prior art that could have been used to refuse the application during the examination process. Another effect of New Zealand's system of publishing patents only after acceptance is that the public has no access to antecedent patent applications, such as parent or grandparent applications, which had not gone through the entire examination procedure itself. This could mean that a potential opponent could not verify whether an application was entitled to an earlier priority date based on an antecedent patent application. ${ }^{273}$

Furthermore, as the term for giving a notice of opposition to the grant of a patent in New Zealand begins with the publication of an application, it is crucial for a third party to know when the publication of an application is expected.

To avoid this complicated situation, most patent regimes have implemented an automatic publication of the patent application 18 months after the earliest priority date. ${ }^{274}$ 


\section{Objections to the Current New Zealand Patent Review System:} Third Party Instruments According to the Patents Act 1953

The New Zealand Patents Act 1953 approach is relatively unique with respect to its instruments for third parties to challenge the grant of a patent. In general, New Zealand's patent regime provides third parties with the following instruments: pre-grant opposition, ${ }^{275}$ revocation before the Commissioner ${ }^{276}$, and revocation by the High Court. ${ }^{277}$

As discussed in Part III B, third-party instruments from different countries, even those of the same type, can differ in the details. In order to provide enough substantial information to analyse the current patent review system in New Zealand, the third-party instruments available will be examined in detail, including the corresponding case law.

\section{$1 \quad$ An hybrid approach}

The current patent review system in New Zealand applies a hybrid approach with an emphasis on adversarial instruments. New Zealand patent law offers third parties specific instruments that provide a strong influence with strict temporal limitations.

\section{Influence of third parties in terms of quantity}

Under the current patent law of New Zealand, third parties have the chance to influence the granting procedure at three points of the process:

(a) First instance: Before grant of a patent - Patent opposition (section 21)

In the first case, third parties have the right to influence the granting procedure by filing an opposition after the IPONZ has carried out its examination and published the complete specification. ${ }^{278}$ Until the 
publication of the complete specification, the application is treated as strictly confidential. Third parties may presume that a patent application could be relevant to their business, but have no right to inspect the files. New Zealand is one of only a few countries worldwide to give third parties the right to file an opposition before the patent is even granted.

(i) When is a pre-grant opposition available?

The earliest possible involvement for a third party in New Zealand's patent-granting process is the opportunity to give a notice of opposition to the grant of a patent. According to section 21 of the Patents Act 1953, a third party can contest the grant of an application within a timeframe of three months from the date of publication of the complete specification on the grounds set. The three-month opposition period can be extended to four months. ${ }^{279}$

(ii) Who can file a pre-grant opposition?

According to section 21(1) of the Act, "any person interested" has the right to oppose the grant of a patent. The Act itself does not define who a "person interested" is, but anybody who wants to oppose a patent application must be directly affected by the grant itself. ${ }^{280}$ Several decisions of the New Zealand Patent Office and the "British Patent Office Manual of Office Practice (Patents) (1949 Act)" provide grounds for standing. Examples include opponents with manufacturing or trading interests related to the same subject matter as the opposed application, or who possess related patents, or who have a clear financial interest in the case. ${ }^{281}$ $\mathrm{McGregor} \mathrm{J}$ on the procedure for obtaining an extension of the opposition period. Ian Finch (ed), above n 10, 56.

281 See Propeller Jet Ltd's Application Commissioner Decision No P27/2005, 29 September 2005, Asst Commr Popplewell; Seda SPA v Huhtamaki Australia Pty Ltd and Michael Horauf Maschinenfabrik GmbH [2010] NZIPOPAT 1 (22 February 2010) Asst Commr Popplewell. 
(iii) Filing a notice of opposition and statement of case

If a third party wishes to oppose the granting of a patent, it must file a notice of opposition (using the prescribed form) ${ }^{282}$ and a statement of case setting out the opponent's standing, the facts the opponent relies on, and which relief he or she seeks in detail. ${ }^{283}$

Whether or not an opposition proceeding is valid when a third party only gives a notice of opposition without a statement of case was recently the subject of debate in New Zealand. Before the decision of the New Zealand High Court in Lacme v Gallagher Group ${ }^{284}$, a common tactic was to file a notice of opposition without a statement of case. This enabled the opponent to gain time in the negotiation process with the patent applicant without losing the possibility of dropping the pre-grant opposition and filing an application for revocation before the Commissioner. In Lacme $v$ Gallagher Group, the High Court held that an opposition is deemed to be filed when the notice of opposition is given, even if no statement of case is filed. In such a case, the opponent could not apply to revoke under section 42.

(iv) Defending an opposition

After the applicant receives a notice of opposition with the statement of case, he must file a counterstatement setting out the response to the opponent's allegations. ${ }^{285}$ The applicant thus has the opportunity to amend his patent application and to defend it against the arguments that the opponent has brought forward. The amendments are be examined by the IPONZ before acceptance.

Patent form 15, see IPONZ New Zealand Intellectual Property Practise Notes 1974 - 1998 (IPONZ, Wellington, 2003) 6. 
(v) Outcome of the pre-grant opposition

After the hearing, the Commissioner issues a decision. In the event that the patent application has been successfully opposed, he or she will either refuse the grant of the patent or request the applicant to amend the application. This decision is open to appeal to the High Court. ${ }^{286}$

(b) Second instance: In-between - Refusal of a patent without opposition (section 22)

The second opportunity for third parties to influence the granting procedure is after the three-month period for opposition but before the grant of the patent. At this stage, the third party can no longer oppose the grant of a patent, because the deadlines for opposition have expired. However, third parties who did not oppose the grant of the patent can file documents to the Commissioner in order to encourage him or her to examine the application using the submitted material, without taking an active part in the procedure.

(i) In general

If no notice of opposition is presented within a three-month period after the publication of the complete specification, the Commissioner has the power to refuse the grant of a patent if it comes to his or her notice that the invention has been previously published in New Zealand. ${ }^{287}$

(ii) What can third parties do?

The refusal procedure in section 22 of the Act differs from the instruments used by third parties to challenge the grant of a patent. It is a mere administrative procedure without any direct involvement of third parties.

However, third parties may exert an indirect influence by submitting information of prior publication or use to the IPONZ without filing an opposition. If the Commissioner is satisfied with the anticipatory material, 
he may refuse to grant the patent unless the applicant is able to amend the application to overcome the objections.

(c) Third instance: After grant of a patent - Revocation proceedings (sections 41, 42)

In this third instance, third parties may exert their influence in two ways. First, they can challenge the validity of a patent in a revocation procedure before the Commissioner. ${ }^{288}$ Second, they may exert their influence by becoming a party before the courts. For example, third parties have the right to file an application for revocation by the court in order to challenge the patent in a validity action. ${ }^{289}$ In addition, a third party may challenge the validity of a patent as a defence in an infringement action. ${ }^{290}$

\section{(i) In general}

Once the patent has been granted, it can be revoked in two ways: either by the Commissioner (section 42) or by the High Court (section 41). There are important distinctions between these two types of revocation procedures. The administrative revocation procedure by the Commissioner can be initiated by 'any person interested' who has not opposed the grant of the patent within 12 months after the sealing of the patent. ${ }^{291}$ The judicial revocation procedure by the Court can be filed by 'any person interested' without restriction on whether or not this person has filed an opposition at any time during the term of the patent. ${ }^{292}$

The most important distinction between the two types of revocation is that the grounds of an administrative revocation by the Commissioner are the same as the grounds of the opposition procedure; in contrast, revocation by the Courts has more extensive grounds. ${ }^{293}$

Ibid, s 42(1).

Ibid.

Ibid, s 41(4).

Ibid,s 42(1).

Ibid, s 41 .

Ibid, ss 42(1) and 41(1)(a)-(m). 
If revocation procedures or infringement actions are pending before any courts, a revocation by the Commissioner is only allowed with the leave of the High Court. ${ }^{294}$ Revocation procedures are thus issued more frequently before the Court than before the Commissioner.

\section{(ii) Revocation by Commissioner (section 42)}

Under the New Zealand patent regime, the revocation procedure by the Commissioner is the last opportunity for a third party to challenge a patent at the administrative level. ${ }^{295}$ This procedure is often referred to as a "belated" or "post-grant opposition" because the procedure and the grounds are similar to the opposition procedure under section 21 of the Act.

The third party must file an application for revocation at any time within 12 months after the sealing of the patent.

Even if a revocation procedure cannot be issued while an infringement action is pending without the permission of the court, a prior revocation procedure can be used to justify an application for a stay in a later infringement process in exceptional circumstances. ${ }^{296}$

(iii) Revocation before court (section 41)

The final possibility for a third party to challenge the validity of a patent (apart from infringement actions) is the revocation before the High Court. ${ }^{297}$ These proceedings have no time limit: an application for revocation of a patent to the High Court can be filed any time during the term of a patent. Section 41 provides an extended list of grounds to challenge the patent. All of these grounds can also be used as a defence and counterclaim in an infringement action. ${ }^{298}$

After a patent has been granted, third parties have only the revocation procedures by the Commissioner to influence the granting if they do not want to go to court. All other opportunities to challenge the validity of a patent take place before courts: for example, revocation by Court or defences against an infringement action.

Ferro Corp v Escol Products Ltd [1990] RPC 651.

Patents Act 1953, 41.

Ibid, s 41(4). 
As the current New Zealand patent regime applies an adversarial approach, third parties have a strong influence on the granting process both before and after the grant of a patent. The influence of third parties before the grant is not limited to the grounds of novelty and obviousness. After the grant of a patent, third parties have several more grounds to challenge its patentability.

(a) Influence of a third party with pre-grant opposition (section 21)

Before the grant of a patent, the New Zealand opposition system allows third parties to oppose the patent application on a multitude of different grounds (see below (i)). Third parties can fully participate in the proceedings; they even have the burden of proof to show that a patent application should not be granted using all kinds of evidence available (see below (ii) and (iii)). An oral hearing is part of the opposition procedure, offering both parties a chance to convince the IPONZ that their perspective on the case is correct (see below (iv)).

(i) Grounds for opposition

Section 21(1) of the Act provides the statutory grounds for opposition in New Zealand. According to these, an opposition procedure challenging the grant of a patent in New Zealand can only be based on the following grounds:

- Obtaining; ${ }^{299}$

- $\quad$ Prior publication or prior use, ${ }^{300}$

- $\quad$ Prior claiming; ${ }^{301}$

- $\quad$ Obviousness by publication or by use $;^{302}$ 
- $\quad$ Not an invention; ${ }^{303}$

- $\quad$ Insufficiency of the description; ${ }^{304}$

- $\quad$ That the convention application was not made within 12 months of the date of first filing overseas; ${ }^{305}$

- When the applicant fails to comply with the terms given after the restoration of an application; ${ }^{306}$

- Undue delay in applying for restoration; ${ }^{307}$ or

- Where an extension of time has been granted by the Commissioner with respect to an application for which an extension was unwarranted. ${ }^{308}$

\section{(1) Obtaining}

Section 21(1)(a) of the Act provides the option that the grant of a patent application can be opposed if the applicant for the patent obtained the invention.

According to Assistant Commissioner Burton in Wade's Application $^{309}$, obtaining an invention is

... something more than 'finding out'. ... mere 'knowledge' of the invention by a particular party cannot be the basis of an allegation of obtaining. Obtaining must surely involve the misuse of such knowledge by some party, i.e. an application for protection of an invention by a person not entitled to apply on contravention of the rights of the person truly entitled to apply ...

If the opponent meets the required high burden of proof to prove obtaining and files an application for the same application, section 62 of the Act gives the Commissioner the right to assign the priority date of the "obtained" application to the opponent's application.

Ibid, s 21(1)(f).

Ibid, s 21(1)(g).

Ibid, s 21(1)(h).

Ibid, s 21(1)(i).

Ibid, s 21(1)(j).

Ibid, s 21(1)(k).

Wade's Application Commissioner's Decision No P01/1981, 9 January 1981, Asst Commr Burton, 8. 


\section{(2) Prior publication}

An application can be opposed on the ground that the invention, as it is claimed in any part of the complete specification, has been published in New Zealand before the claim's priority date. ${ }^{310}$

In other words, an invention as it is claimed in the complete specification of the application lacks novelty if it has been published in New Zealand before the priority date of the application. Not included in the relevant prior art base are patent specifications which were published in New Zealand more than 50 years before the date of filing and documents which were not published in New Zealand.

According to section 2(1) of the Act, a document is "published" when it is made available to the public.

Particularly noteworthy is that prior publication is only a ground for opposition if the information has been made available to the public within New Zealand. Thus, a prior publication available only in another country cannot be used to oppose a New Zealand patent application: this is what defines New Zealand as a local novelty country. However, if a foreign document has been available electronically via the Internet in New Zealand before the priority date of the application, the opponent may use this information as evidence to prove the lack of novelty. In Molecular Plant Breeding Nominees Ltd's Application, Assistant Commissioner Popplewell stated: ${ }^{311}$

Any person who accesses a document on the Internet is free to download or print it; thus it seems to me that this would be analogous to a facsimile of a document being sent from overseas to a New Zealand resident — such a document would surely fall within the definition of s 2 .

The same test was used in Agriculture Victoria Service Pty Ltd's Application. ${ }^{312}$

Patents Act 1953, s 21(1)(b).

Molecular Plant Breeding Nominees Ltd's Application, Commissioner Decision No P25/2005, 12 September 2005, Asst Commr Popplewell, 27.

Agriculture Victoria Service Pty Ltd's Application, Commissioner Decision No P26/2005, 12 September 2005, Asst Commr Popplewell. 
Additionally, prior art documents can only anticipate the invention as claimed if they pass the "reverse infringement" test established in General Tire \& Rubber Co v Firestone Tyre \& Rubber $\mathrm{Co}^{313}$ and applied by the Supreme Court of New Zealand in Peterson Portable Sawing Systems Ltd (in liq) v Lucas. ${ }^{314}$

The requirements of the "reverse infringement" test were summarized in Sealed Air NZ Ltd v Machinery Development Ltd ${ }^{315}$ as follows:

... the test is to consider the document relied upon as constituting prior publication, and to determine whether that clearly

(a) describes something that would infringe the claim, or

(b) instructs something to be done or made which would infringe the claim, or

(c) gives directions, the carrying out of which would inevitably result in infringement of the patent applied for.

The House of Lords reviewed the test of prior publication in Synthon $B V v$ Smithkline Beecham Plc. ${ }^{316}$ Lord Hoffmann defined therein two distinct requirements for prior publication (or anticipation): prior disclosure and enablement. According to Lord Hoffmann, the disclosure condition is satisfied whenever the subject matter of the prior disclose can be performed and results in a patent that is infringed. Enablement means that an ordinarily skilled person would be able to create the invention. ${ }^{317}$

The origin of the test, the landmark decision General Tire \& Rubber Co v Firestone Tyre \& Rubber $\mathrm{Co}^{318}$ held:

To anticipate the patentee's claim, a prior publication must contain clear and unmistakable directions to what the patentee claims to have invented ... ${ }^{319}$ A signpost, however clear, upon the road to the patentee's invention will not suffice. The prior inventor must be Tire]. Peterson Portable Sawing Systems Ltd (in liq) v Lucas [2006] 3 NZLR 721 (SC), para 3 [Peterson]. 
clearly shown to have planted his flag at the precise destination before the patentee.

\section{(3) Prior claiming}

A patent application may be opposed on the ground that an invention has been claimed in another complete specification and was published on or after the priority date of the application but was filed in advance of this date. $^{320}$

The requirements for this ground are satisfied if another patent application with the same invention was filed before but published on or after the priority date of the opposed application.

Particularly difficult to prove in an opposition procedure is that any claim of the opposed application has already been claimed. ${ }^{321}$ However, mere differences in the language of claims that do not substantially change the subject matter are irrelevant. ${ }^{322}$ On the other hand, an opposition procedure on the ground of prior claiming will fail if the prior claim lacks just one essential feature ${ }^{323}$ - even if the later claim falls within the scope of protection. ${ }^{324}$ As a result, opposition procedures based on prior claiming are quite uncommon.

\section{(4) Prior use}

The grant of a patent application can also be opposed on the basis that the invention was used in New Zealand before the priority date of the application. ${ }^{325}$

According to a practise note of the IPONZ ${ }^{326}$ based on the decision of the House of Lords in Bristol-Myers (Johnson's) Application, ${ }^{327}$ in order for an opposition to succeed on this ground, the opponent must first,

Patents Act 1953, s 21(1)(c).

General Tire, above n 313, 486, per Sachs LJ, stating that: "[t]he prior inventor must be clearly shown to have planted his flag at the precise destination before the patentee." See Commercial Solvents Corp's Application (1954) 71 RPC 143. Re Viskase Corporation's Application (New Zealand Patent Office, IP No 215759, 10 July 1998, Asst Commr Popplewell). 
... establish that the alleged instance(s) of prior use was (were) not secret use(s) of the invention, as claimed. ...

and second,

The opponent must also establish, by evidence,
(a) what was used
(b) where it was used
(c) by whom it was used
(d) the dates it was used
(e) where apparatus still extant may be inspected.

This means that a challenge on the basis of prior use will fail if the prior use of the invention was secret. The House of Lords in Bristol-Myers (Johnson's) Application held that an invention is secretly used if the user intentionally conceals it. ${ }^{328}$

Furthermore, the prior use must be "in a public manner". ${ }^{329}$ Thus, the private use of an electric blanket manufactured overseas has been held to be insufficient to support an opposition based on prior use. ${ }^{330}$ In addition, to oppose a patent application on the ground of prior use, it is sufficient to prove only a single instance of prior use, ${ }^{331}$ but the lack of a specific example of prior use will result in failure for the opposition. ${ }^{332}$ In Georgeson $v$ Urwin and $\mathrm{Co}^{333}$ it was held that a certain amount of experimental use does not result in the loss of novelty.

Section 60 of the Act provides statutory exceptions to prior use: for example, an invention disclosed at a "gazetted exhibition", disclosed to a Government department, or used for the purposes of reasonable trial and experiment.

IPONZ New Zealand Intellectual Property Practice Notes 1974 - 1998 (IPONZ, Wellington, 2003) Issue No 1287.

Bristol-Myers Co (Johnson's) Application (1975) 92 RPC 127, 157.

Ibid.

Ralta Ltd's Application Commissioner Decision No P05/1985, 16 April 1985, Asst Commr Burton, 6.

Ibid.

For example, Craig \& Connelly's Application Commissioner Decision No P03/1982, 17 March 1982, Asst Commr Burton.

See Re Application of Eighth Milieu Nominees Pty Ltd [1992] NZIPOPAT 8 (10 June 1992), Asst Commr Burton.

Georgeson v Urwin and Co [1928] NZLR 207 (SC). 


\section{Obviousness}

Unlike most other national Patent Offices, the examination by the IPONZ does not include the question of whether or not the invention is obvious. The examiner can only refuse the application if the invention does not meet the requirements of an "invention" as defined in section 2(1) of the Act. By that standard, an invention only needs to be a manner of new manufacture. However, it is possible to oppose a patent application if the invention is obvious and clearly does not involve an inventive step. ${ }^{334}$

This ground involves two separate and distinct areas: obviousness or lack of inventive step with regard to prior publication and with regard to prior use. ${ }^{335}$

In opposition proceedings, the opponent must show that the invention is clearly obvious; otherwise, the applicant will be given the benefit of doubt.

In Beecham Group Ltd v Bristol Myers Company (No 2), ${ }^{336}$ it was decided that the insertion of the word "clearly" in section 21(1)(e) of the Act shows that the opponent has an higher onus of proof using the ground of obviousness in opposition procedures than in revocation procedures. ${ }^{337}$ Furthermore, Barker $\mathbf{J}$ held in the same decision that obviousness is to be judged from the viewpoint of a "notional" addressee who is a skilled technician, knowledgeable in the relevant literature, but incapable of a "scintilla of invention". ${ }^{338}$

As summarised in Bernard Charles Sherman v Merck \& Co Inc, ${ }^{339}$ the two leading New Zealand appellate authorities on obviousness are Ancare v Cyanamid $^{340}$ and Peterson Portable Sawing Systems Ltd $\mathrm{v}$ Lucas. ${ }^{341}$ These

Patents Act 1953, s 21(1)(e).

IPONZ New Zealand Intellectual Property Practice Notes 1974 - 1998, above n 329.

Beecham, above n 269, 230, Barker J.

Section 41(1)(f) of the Act lacks the word "clearly".

Beecham Group Ltd v Bristol Myers Company (No 2) [1980] 1 NZLR 192.

Bernard Charles Sherman v Merck \& Co Inc [2007] NZIPOPAT 21 (13 August 2007).

Ancare NZ Ltd v Cyanamid of NZ Ltd [2000] 3 NZLR 299 (CA) (upheld in a judgment of the Privy Council [2003] RPC8) [Ancare]. 
cases held that under New Zealand law, the principals of obviousness "are the same as those adopted in England and applicable under the Patents Act 1977 (UK)". ${ }^{342}$ Therefore, the four-stage analysis as a test for obviousness set out in the landmark decision Windsurfing Inc v Tabur Marine (GB) Ltd ${ }^{343}$ is still applicable in New Zealand. ${ }^{34}$ Accordingly, the ground of obviousness is not justifiable if the difference between the prior art and the alleged invention is obvious to a "normally skilled but unimaginative addressee". ${ }^{345}$

In New Zealand, two different approaches exist when the court is asked to filter out prior art which could not be found by such a skilled person. In Beecham Group Ltd v Bristol Myers Company (No 2), ${ }^{346}$ the diligent searcher approach used in Australia was applied. However, in Ancare NZ Ltd $v$ Cyanamid of NZ Ltd, ${ }^{347}$ the court held that it is not necessary to decide whether a diligent searcher would have found the prior art or whether all documents should be taken into consideration. The 'all document' approach has been confirmed by the High Court in Cool 123 Ltd $v$ Vodafone NZ Ltd. ${ }^{348}$ As a result, prior art cannot be excluded from consideration in New Zealand.

In some cases, although the prior art documents lack one or more features of the invention, they form in their entirety a mosaic supplying all necessary features. Thus, while it is not permissible to combine instances of

Ibid, para 54 .

Windsurfing Inc v Tabur Marine (GB) Ltd (1985) 102 RPC 59, 73-74 (CA) [Windsurfing]. Followed by the New Zealand High Court in Smale v North Sails Limited [1991] 3 NZLR 19, followed in the New Zealand Court of Appeal by Gault J in Ancare, above n 340, 309, and confirmed by the New Zealand Supreme Court in Peterson, above n 314, para 54.

The test includes following steps: (1) considering the inventive concept of the alleged invention, (2) considering the prior art or prior use, (3) identifying differences between prior art and the alleged invention, and (4) asking whether the differences would have been clearly obvious to a "normally skilled but unimaginative addressee" at the priority date, see Crusader Engingeering Limited v Mattersmiths Holdings Limited and Juken New Zealand Limited [2009] NZIPOPAT 22 (23 November 2009) Asst Comm Hazlewood. However, in the United Kingdom, the Court of Appeal recently reformulated the steps of the Windsurfing approach, see Pozzoli SPA v BDMO SA [2007] EWCA Civ 588.

See Seda SPA v Huhtamaki Australia Pty Ltd and Michael Horauf Maschinenfabrik GmbH [2010] NZIPOPAT 1 (22 February 2010) Asst Comm Popplewell.

Beecham, above n 338, 230, Barker J.

Ancare, above n 340, para 43.

Cool 123 Ltd v Vodafone NZ Ltd (29 August 2007) HC WN CIV-2006-485-698 Simon France J. 
prior use and prior publication for obviousness, it is allowable to piece together a number of prior art documents if the "notional addressee" would normally combine them. ${ }^{349}$

The last step of the Windsurfing test is the determination of whether the differences between the prior art and the alleged invention would have been clearly obvious to a "normally skilled but unimaginative addressee" at the priority date. Different countries utilise a variety of approaches in addressing this issue. ${ }^{350}$ In New Zealand, the 'worthwhile to try' approach has been used. ${ }^{351}$

In addition, in Lucas $v$ Peterson Portable Sawing Systems Ltd, ${ }^{352}$ the Supreme Court of New Zealand decided that a mere combination of already known features without new functions does not involve an inventive step. ${ }^{353}$

With regard to this decision and the 'all documents' approach, it seems that the threshold for an inventive step is higher in New Zealand in comparison to other patent regimes - Australia, for example. ${ }^{354}$ Consequently, it might seem that New Zealand's approach to obviousness would make it easier to invalid a patent there than in other countries. ${ }^{355}$ However, even though the obviousness approach is the same for opposition procedures and revocation, "it is unlikely that an opponent can succeed on this ground", ${ }^{356}$ as Assistant Commissioner Burton stated. The reason is that the burden of proof is higher in opposition proceedings than for revocation,

Ancare, above n 340, para 43.

For example, in Europe, the problem-solution approach is preferred, while in the United States and Australia, the 'obvious to try' approach is preferred, see Aktiebolaget Hassle v Alphapharm Pty Ltd [2002] HCA 59, Lockwood Security Products Pty Ltd v Doric Products Pty Ltd 235 ALR 81; 81 ALJR 1070. Ancare, above n 340 , para 43.

Peterson, above n 314 .

Unlike Australia, see Lockwood Security Products Pty Ltd v Doric Products Pty Ltd (No 2) [2007] HCA 21, para 132.

354 Anton Blijlevens, above n 91, 434

355 See discussion in Novartis New Zealand Ltd v Aktiebolaget Hassle [2004] 2 NZLR 721, para 32.

356 George Oscar Kohler and Emanuel M. Bickoff v Licencia Talalmanyokat Ertekesito Vallalat [1981] NZIPOPAT 9 (10 June 1981). 
because in opposition procedures, the applicant needs to show that the invention clearly does not involve an inventive step. ${ }^{357}$

(6) Not an invention

Under section 21(1)(f), the opponent may challenge the grant of a patent on the ground that it is not an invention within the meaning of the Act. $^{358}$

According to New Zealand case law, this ground can be used if the patent application is based on an invention that is not a manner of new manufacture or if it consists of a mere discovery, ${ }^{359}$ a mere scheme or plan, ${ }^{360}$ a mere collocation of integers, ${ }^{361}$ or a method of medical treatment. ${ }^{362}$

\section{(7) Insufficient description}

According to section 21(1)(g) of the Act, a patent application can be opposed on the ground of insufficient description of the invention or of the method by which the invention is to be performed. The ground of insufficiency is based on the assumption that it is the duty of the applicant to provide full and sufficient information for the public by describing first, the nature of the invention and second, the manner by which the invention is to be performed. ${ }^{363}$

An allegation of insufficiency of the complete specification involves two factors:

Beecham Group v Bristol-Myers Company (No 2), above n 269, 230, per Barker J. The term "invention" is defined in section 2(1) of the Act as follows:

'Invention' means any manner of new manufacture the subject of letters patent and grant of privilege within section 6 of the Statute of Monopolies and any new method or process of testing applicable to the improvement or control of manufacture; and includes an alleged invention.

See Reynolds v Herbert Smith and Co Ltd (1903) 20 RPC 123; Maunder v Wanganui Sash \& Door Factory \& Timber Co Ltd [1928] NZLR 566.

See Rolls-Royce Ltd's Application [1963] RPC 251; IBM Corps Application [1980] FSR 564.

See Peterson, above n 314.

See Wellcome, above n 243 .

American Cynamid Co (Damn's) Patent (1971)54 RPC 425 (HL), Valensi and Another v British Radio Corporation [1973] RPC 337, 377. 
(1) that the complete specification does not sufficiently and fairly describe the invention; and

(2) that the complete specification does not sufficiently and fairly describe the method by which the invention is performed.

An opposition procedure based on the ground of insufficiency of the description will fail if the applicant meets the standard applied in Edison and Swan United Electronic Co v Holland. ${ }^{364}$ According to this decision, a description is sufficient if a person with reasonable skill is able to perform the invention. If the user is unfamiliar in the use of this method or invention, then the applicant needs to guarantee that a competent person would be able to understand how to proceed by reading the specification. ${ }^{365}$

Thus, due to an insufficient description or an error in the specification, a specification may be invalid, as the invention claimed would not work as described..$^{366}$

It should be noted that the ground of insufficiency ought not to be confused with the ground of inutility. ${ }^{367}$ A patent application can only be challenged based on inutility in a revocation process.

\section{(8) Other grounds}

There are four other possible grounds for opposition provided by sections 21(1)(h) to 21(1)(k) of the Act, including more formal reasons for an patent application to be opposed by a third party.

\section{(ii) Burden of proof}

The onus of proof to prevent an application from being granted lies with the opponent. This means that the third party filing an opposition needs Ibid.

Kabushiki Kaisha Toshiba v Fisher \& Paykel Limited [2005] NZIPOPAT 8 (11 April 2005); Valensi and Another v British Radio Corporation [1973] RPC 337, 377. 
first to submit the grounds for opposition and must then prove that the application is not suitable for grant.

It is not the function of the opposition procedure to determine definitively the validity of a patent application. ${ }^{368}$ According to New Zealand High Court case law, the opposition procedure only deals with the question of whether or not a patent application is "manifestly untenable". ${ }^{369}$ If this question cannot clearly be answered in an opposition procedure, then the High Court must take up the claim for invalidity in a revocation process. ${ }^{370}$ As Berker J said in Beecham Group Ltd v Bristol Meyers Co (No 2), ${ }^{371}$

I shall ask myself the questions in respect of each ground of opposition; is the claim to the patent in suit 'manifestly untenable'? Is there a prima facie case for the grant of the patent? Does the justice of the case require the applicant to be permitted to resist the claim for invalidity in properly constituted revocation proceedings? All these tests, although differently stated, really amount to the same thing.

With regard to the onus of evidence, according to section 96(1) of the Act, evidence admitted in the proceedings before the Commissioner may be given by affidavit or statutory declaration. Furthermore, the Commissioner may "if he thinks fit in any particular case take oral evidence instead of or in addition to such evidence. ${ }^{372} \mathrm{He}$ also has the right to allow the crossexamination of witnesses on their affidavits or declarations. Concerning the evaluation of evidence filed in opposition procedures, Diplock LJ states: ${ }^{373}$

...look at the evidence filed on behalf of the applicants and the opponents in order to see (1) whether the opponents' evidence read by itself clearly establishes the opponents' case, and, if so, (2) whether

See $R v$ Patents Appeal Tribunal, ex parte Swift and Co [1962] RPC 37, 46 Lord Parker. See Sealed Air NZ Ltd v Machinery Developments Ltd, above n 315; Beecham, above n 338; Saxpack Foods Ltd v J Watties (11 July 1988) HC WN M454/85 Ongley J

In Swift \& Co's Application [1962] RPC 37, the principle was stated that an opposed application should only be refused in the clearest possible cases.

Beecham, above n 338, 213.

Patents Act 1953, s 96(1). In Malik M Hasan v Ministry of Health, Accident Compensation Corporation, Telecom New Zealand Limited [2009] NZIPOPAT 6 (5 May 2009), Asst Commr Hazlewood decided that all grounds of opposition are to be heard at one single hearing. Therefore, evidence need to be delivered completely to the applicant in advance, see Patent Regulations 1953, reg 50.

General Electric Company's Application [1964] RPC 413, 455-456. 
the applicants' evidence in reply raises any bona fide conflict of fact or expert opinion on a question on the answer to which the opponents' case depends.

(iii) Filing evidence

Under Regulations 50 and 51 of the Act, both parties have two months to file evidence in support of their cases. The evidence is to be given to the Commissioner in the form of a statutory declaration or affidavit, or as oral evidence if he sees fit. ${ }^{374}$

(iv) Hearing

Section 21(3) of the Act provides for a hearing before the Commissioner. After the applicant files its counterstatement and all evidence is compiled, the Commissioner appoints a hearing at least 14 days in advance, if all parties have not elected to be heard in a written procedure. ${ }^{375}$

(b) Influence of a third party without filing an opposition (section 22)

If a third party does not want to file an opposition, but has material relevant to the application, he or she can make the Commissioner aware of the evidence by simply filing these documents with the IPONZ. As the third party has no direct influence, it depends entirely on the Commissioner whether or not he or she uses the information provided by a third party. Third parties bringing anticipatory material to the Commissioner's attention have no right to file further submissions in support, but it is generally accepted that the applicant may file a submission in response to the findings of the Commissioner. ${ }^{376}$

Patents Act 1953, s 96(1).

Patents Regulations 1953, reg 54.

As the applicant has the right to file a submission in response to the objections under section 13 of the Act, and the documents cited by the Commissioner have the same subject matter under section 13 as under section 22, the circumstances are analogous. 
However, it is possible to submit documents under section 22 and to file an opposition under section 21 simultaneously. As the hearing officer must consider all information brought to his attention, even after the hearing but before the grant of the patent, anticipatory material submitted under section 22 can also be used in an opposition procedure under section 21 of the Act. ${ }^{377}$

(c) Influence of a third party in revocation procedures and before the court (section 41 and 42)

After grant of the patent, third parties have two opportunities to exert their influence. The third party can either apply to the Commissioner for an order revoking the patent on the same grounds upon which the application could be opposed, or they can file an application for revocation to the courts, challenging the grant of a patent on even more possible grounds. In both procedures, the third party fully participates as a party to the proceedings and must prove that the patent is invalid. An oral hearing is also included in the revocation proceedings.

(i) Burden of proof and evidence

As Tomlin $\mathrm{J}$ in In the Matter of Lowndes' Patent stated, the burden of proof lies on the person who applies for the revocation of the patent: ${ }^{378}$

I think that, where an application is being made for the revocation of a patent which bas been granted, there is no doubt that the applicant is under the duty or burden of making out his case in the clearest way. It seems to me that that must follow from the very nature of the proceeding.

As in the opposition procedure, evidence in revocation proceedings before the Commissioner can be given either by affidavit or by statutory declaration. ${ }^{379}$ 
For a revocation proceeding before the High Court, evidence must be given according to the High Court Rules. ${ }^{380}$

(ii) Grounds for revocation

The grounds for revocation before the Commissioner are similar to the grounds in section 21 of the Act. Therefore, the aforementioned grounds for opposition are applicable for the revocation procedure before the Commissioner.

The revocation process under section 41 of the Act has essentially the same grounds as the opposition procedure, although the grounds are generally wider in scope. In the following section, only the differences between these grounds will be discussed; for the most part, the explanations above for the grounds for opposition apply. The grounds for revocation include:

- $\quad$ Prior granting ${ }^{381}$

- $\quad$ Applicant not entitled to apply ${ }^{382}$

- $\quad$ Obtaining 383

- $\quad$ Not an invention ${ }^{384}$

- $\quad$ Lack of novelty 385

- $\quad$ Obviousness ${ }^{386}$

- $\quad$ Inutility $^{387}$

- $\quad$ Insufficient description ${ }^{388}$

- $\quad$ Ambiguity 389

- $\quad$ False suggestion / representation ${ }^{390}$ 
- $\quad$ Secret use $\mathrm{e}^{391}$

- $\quad$ Contrary to the law ${ }^{392}$

\section{(1) Obtaining}

Unlike in opposition procedures, the ground of obtaining in revocation proceedings is not limited to obtaining the invention from the true and first inventor or its personal representative. ${ }^{393}$

\section{(2) Lack of novelty}

The challenge of a patent in a revocation process based on the lack of novelty will be successful if the applicant can prove that the invention was either known or used in New Zealand before the priority date of the patent. ${ }^{394}$ In contrast to the ground of prior publishing for opposition, ${ }^{395}$ the broader term "known" instead of "published" is utilised for this ground. Therefore, in a revocation process, it is also possible to anticipate an invention with oral disclosure.

\section{(3) Obviousness}

In general, it is easier to succeed with this ground in revocation proceedings than in opposition procedures. Firstly, in revocation proceedings, it is necessary to show that the claimed invention is "obvious and does not involve any inventive step having regard to what was known or used before the priority date of the claim in New Zealand," ${ }^{396}$ whereas in opposition procedures, the invention needs to be "clearly" obvious. ${ }^{397}$ This means that the burden of proof for obviousness is markedly higher in an 
opposition procedure. ${ }^{398}$ Secondly, regarding prior disclosure, the scope of the ground of obviousness in revocation proceedings is broader because it is not limited to "published" disclosure.

\section{(4) Inutility}

An additional objection to the validity of a patent in revocation proceedings is inutility. ${ }^{399}$ In Fawcett $v$ Hoffmann, ${ }^{400}$ the English Court of Appeal defined utility as follows:

If an invention does what it is intended by the Patentee to do, and the end attained is itself useful, the invention is a useful invention.

In Smale v North Sails Ltd, ${ }^{401}$ the High Court of New Zealand held that the test of utility is satisfied "if the result is that the object sought to be obtained can be attained and is practically useful ..."402 Consequently, this ground is rarely successful, because the invention needs only to fulfil one of its objectives to be useful.

\section{(5) Insufficient description}

A patent may be revoked if the "complete specification does not sufficiently and fairly describe the invention and the method by which it is to be performed, or does not disclose the best method of performing it". ${ }^{403}$ In contrast to opposition procedures, this ground requires that the specification disclose "the best method of performing". This second part has been interpreted in E/I du Pont Nemours \& Co $v$ Enka $B V^{404}$ as imposing three requirements. Hon Falconer J stated: ${ }^{405}$

399 Patents Act 1953, s 41(1)(g). See, for example, Maeder v "Ronda" Ladies' Hairdressing Salon [1943] NZLR 122 (SC and CA), a case in which a hairdresser performed the method described in the patent before the court in order to show that it did not work.

Ibid.

Patents Act 1953, s 41(1)(d).

E/I du Pont Nemours \& Co v Enka BV [1988] FSR 69.

Ibid, 87-88, (referring to Patents Act 1949 (UK), s 32(1)(h)). 
... to succeed on this ground a defendant has to establish three requirements in respect of that matter not disclosed in the specification and which is relied upon (the "omitted matter"), namely:

(i) the omitted matter must disclose a method of performing the invention better than any disclosed in the complete specification of the patent;

(ii) the method disclosed in the omitted matter must have been known to the applicant for the patent as better than any disclosed in the complete specification, and,

(iii) be a method for which the applicant was entitled to claim protection.

\section{(6) Ambiguity}

A patent can be revoked if the scope of a claim is insufficient and unclearly defined, or if it is not fairly based on the disclosed matter. ${ }^{406}$

This ground consists of two quite different bases:

- that the definition is not sufficiently and clearly defined, and/or

- that the claims are not fairly based on the disclosure in the specification.

As Dennison J stated in Daily $v$ Lightband, ${ }^{407}$ in order to sufficiently and clearly define the specification, a definition "... is to be such that a person of ordinary intelligence, conversant with the subject matter, will understand it, and will be able to act upon it." 408

With regard to the second base, there are three rules held by Lloyd Jacob J in Mond Nickel Co Ltd's Application ${ }^{409}$ to determine whether or not a complete specification is fairly based: ${ }^{410}$

Firstly, one has to enquire whether the alleged invention as claimed can be said to have been broadly described in the provisional specification ...

Patents Act 1953, s 41(1)(i).

Daily v Lightband (1903) 6 GLP 135.

Ibid, 136.

Mond Nickel Co Ltd's Application (1956) 73 RPC 189; applied in Allied Chemical Corporation v Commissioner of Patents [1970] NZLR 166.

Mond Nickel Co Ltd's Application, above n 409, 194. 
Is there anything in the provisional specification which is consistent with the alleged invention as claimed? ...

Does the claim include as the characteristics of the invention a feature as to which the provisional specification is wholly silent?

(7) False suggestion

There is a ground for revocation if a "patent was obtained on a false suggestion or representation." ${ }^{411}$ This ground is not available in an opposition procedure.

As the Court of Appeal in Valensi v British Radio Corporation Ltd ${ }^{412}$ ruled, a revocation proceeding based on this ground may be successful if the applicant shows that the misinterpretation made by the patentee was of such materiality that the Crown was misled into granting the patent. It is not possible to challenge the grant of a patent because it was obtained in the absence of good faith, unless the challenge can be brought under the ground of false suggestion. ${ }^{413}$

(8) Secret use

A patent may revoked if the invention was secretly used in New Zealand. ${ }^{414}$ In determining whether a secret use has taken place, no importance is given to: (1) use of the invention for reasonable trials or experiments, ${ }^{415}$ (2) use by the government or any person authorised by a Government Department, ${ }^{416}$ or (3) use by a person without the consent or acquiescence of the applicant or of any person from whom he derives title. ${ }^{417}$

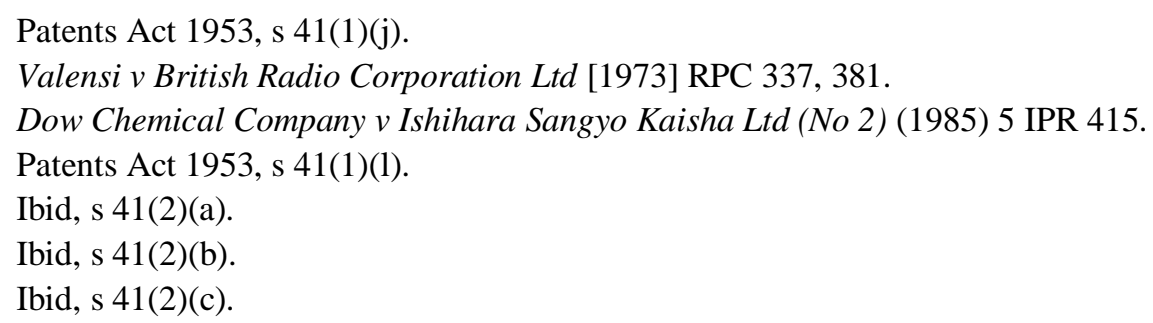


(9) Contrary to the law

A patent may be revoked if it "has been granted contrary to law." 418 This ground gives a third party the right to apply for revocation of a patent on any other ground on which the patent could have been refused apart from the grounds in subparagraphs (a) to (1) of section 41(1) of the Act. ${ }^{419}$ However, in Dow Chemical Co v Ishihara Sangyo Kaisha Ltd, ${ }^{420}$ Eichbaum $\mathrm{J}$ considered and limited this provision as follows:

The legislature having carefully codified the law in 12 preceding subparagraphs, I do not believe that be means of the broader provisions of the 13th it should have intended to throw open an examination of the entire pre-existing common law,...

\section{$4 \quad$ Advantages and disadvantages of this system}

As shown above, the current patent review system of New Zealand shifts the burden of reviewing patents completely to third parties. If they have relevant information as to why an application should not be granted or concerning the doubtful validity of a patent, third parties can initiate adversarial proceedings to challenge a patent. This system is advantageous because the third party has several instruments to effectively challenge a risky application or patent. As the procedure does not limit the kind of evidence that can be used, the possibilities of challenging are manifold. Even inventions based on new technology having predominantly non-patent prior art may be effectively challenged .

Pre-grant opposition even gives third parties the right to challenge an application before the applicant has obtained a monopoly to block competitors from the market. This means that the challenger does not face the risk of provoking an infringement action based on the matter in dispute. In patent regimes that provide only a post-grant opposition procedure, it is not uncommon that challenging the validity of a patent will demonstrate to

Ibid, s 41(1)(m).

This ground was inserted by the Evans Commission in order to provide an equivalent of the writ of scire facias, see Evans Commission H-10A 29 June 1950, paras 200 and 201.

Dow Chemical Co v Ishihara Sangyo Kaisha Ltd (19 December 1983) HC WN M653/83. 
the patentee that a patent has relevance to the products of a competitor. As a result, the patentee might sue the opponent in a parallel infringement action.

The current New Zealand patent review system also has many disadvantages. In particular, the third party can only oppose the application within the brief time period of three months. As the complete specification is first available only after publication, third parties actually have only weeks to find relevant prior art. The search for relevant prior art (including material that is not in patent databases) may take too long to allow a realistic chance of opposing an application. As a result, the opposition procedure can have a low chance of success.

Furthermore, the current patent review system provides no instrument for a third party to submit relevant information at an early stage of the procedure. As the publication of the complete specification happens after the IPONZ has already carried out the complete examination of the application, third parties have no chance to support the IPONZ with relevant prior art without opposing the application. As a result, relevant prior art may not be considered, because a third party might not invest the money to oppose an application in cases in which the risk a patent represents for their products is not so high.

\section{Intermediate Result}

In principle, New Zealand's current review system as a hybrid approach has the potential to effectively enhance the quality of patents when third parties make use of the available instruments. The current patent review system provides several third-party instruments giving third parties a strong and early influence in order to challenge overly broad or invalid patents. However, the current system does not allow third parties to support the IPONZ before the grant of a patent with relevant prior art without opposing the application. Furthermore, the influence of third parties before the grant of a patent is temporally limited in a way that makes it difficult to search for prior art in depth. Moreover, the cost-efficient administrative procedures of the IPONZ are more limited with respect to the grounds available than the proceedings in the courts. 
It may be beneficial to adapt the current patent review system of New Zealand to support the IPONZ with more relevant prior art, preserving and improving its ability to function. A revise would also promote third-party actions to challenge applications or patents of doubtful validity by providing a more effective and less costly way to do so.

\section{REFORM PROCESS IN NEW ZEALAND}

The reform process for New Zealand patent law has been ongoing for decades, but without significant changes to the Patents Act 1953. The reason for the lack of progress is that revisions of the entire patent system have been attempted. However, in recent years, important steps toward a modern patent system have been made. For instance, the patent review system of New Zealand has been revised with regard to its third-party instruments. The following section of this dissertation provides an overlook of the reform process of New Zealand's reviewing system. In particular, the Patents Bill 2008 , as an outcome of the reform process that proposes significant changes in the patent review system, will be analysed in detail. In order to understand how the new patent law proposed by the Patents Bill 2008 has been developed, it is also necessary to briefly illustrate the history of the reform process, developments in patent policy, and the discussions related to the review of the Patents Act 1953 from its beginning up to the present day.

\section{A History of Reform}

The New Zealand Patents Act 1953 has been in force for more than half a century without any significant changes to the law. By contrast, corresponding legislations in the United Kingdom and Australia have been continuously altered, reacting with flexibility to technological developments. ${ }^{421}$ The release of the draft Patents Bill in 2004 and the introduction of the Patents Bill 2008 to the Parliament are the first steps in updating New Zealand's patent law; they have initiated substantial debate 
over what sort of patent law would be most appropriate to the needs of the country.

\section{$1 \quad$ Government reports with respect to patent law}

There have been previous attempts to review New Zealand's patent laws, but none of these has led to a comprehensive revision of the system as a whole. ${ }^{422}$ Official reports at the beginning of the 1990 s, responding to the law reforms in Australia, recommended modernization of the legislation, which did not finally take place until more than 14 years later. In its report from 1990, the Law Commission recommended: ${ }^{423}$

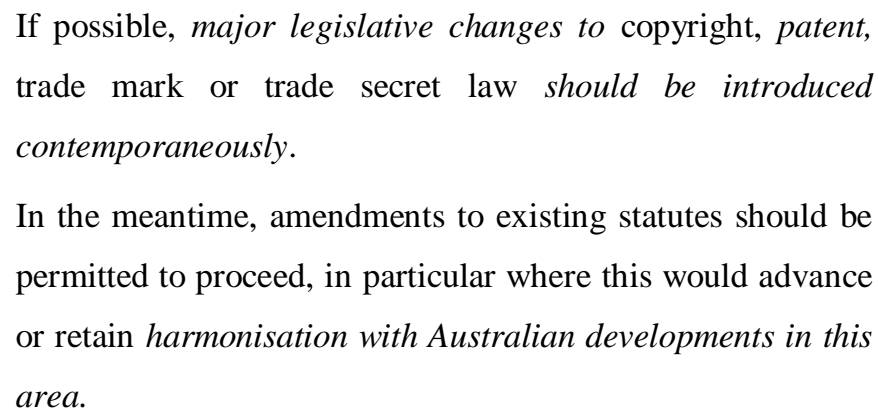

In the same report, the Law Commission also pointed out public policy issues of intellectual property that provided a framework for the later reform process. The questions that the report posed were: ${ }^{424}$

Does intellectual property law strike the right balance between the interests of right holders, consumers and competitors?

Does intellectual property law strike the right social balance between short-term price increases and long-term innovation?

In 1985 , the Industrial Property Advisory Committee (IPAC) reported on the extension of the patent term from 16 to 20 years, see IPAC Report The Patent Monopoly Term and Extensions Thereof" (Industrial Property Advisory Committee, Wellington, 1985). In 1987, the IPAC discussed the review of New Zealand's patent law with respect to microorganism inventions, see IPAC Report The Adequacy of Definition and Disclosure in Patent Specifications Relating to Micro-Organism Inventions (Industrial Property Advisory Committee, Wellington, 1987). 
Should profit maximisation or cost recovery be the State's aim when assessing fees for intellectual property?

Should term of grant and social benefit be more evenly matched?

Does resolution of the foregoing issues require a more unified intellectual property law or should we dissect and reassemble that law so that it reflects more closely the personal and business interests sought to be protected rather than the often fortuitous and largely historical patentcopyright-trade mark division?

In addition, the Minister of Commerce announced in July 1989 a review of the Patents, Trade Marks and Design Acts. The first stage of this review was the publication in 1990of a discussion paper identifying possible options for reform with respect to the intellectual property regime in New Zealand. ${ }^{425}$ The topics discussed in this paper were the implementation of international treaties, such as the TRIPs Agreement and the proposed World Intellectual Property Organisation (WIPO) treaties on harmonisation of the law, as well as other patent law issues (concerning compulsory licensing, the patent term, and the protection of micro-organisms and biotechnological inventions). In 1992, an additional discussion paper was issued. ${ }^{426}$ In accordance with New Zealand's policy for issues concerning the Māori and biotechnology, in 1999 the Ministry of Commerce published a discussion paper on the patenting of life forms and the Māori. ${ }^{427}$

In 2000, the Government agreed to a three-stage review of the Patents Act 1953 to account for the social and technological changes in the world since the Act came into force. In Stages 1 and 2 of the review, the Cabinet dealt with technical and operational changes to the Act, with a focus on updating New Zealand's patent legislation. Proposed amendments were, for example, the implementation of an absolute (rather than local) novelty standard and the examiner's determination of an inventive step as a

Possible Options for Reform, above n 16.

Ibid.

Ministry of Commerce Maori and the Patenting of Lifeform Inventions An Information Paper Produced by the Patenting Lifeforms Focus Group for the Ministry of Commerce (Ministry of Commerce, Wellington, 1999). 
requirement for the grant of a patent. Stage 3 of the review considered more complex issues; a discussion paper on this stage was released in March $2002 .^{428}$ These issues included the definition of the term "invention", the stringency test for patents in New Zealand, and the patentability of biotechnology, business methods, software, and methods of medical treatment of humans.

\section{$2 \quad$ Draft Patents Bill 2004}

The first substantial outcome of the review process was the release of the Draft Patents Bill in 2004 by the Ministry of Economic Development, for the purpose of giving professionals the opportunity for consultation. ${ }^{429}$ This step is normally not required in the legislative process, but it was useful at this time, as it opened up a broader forum to discuss highly controversial topics. ${ }^{430}$ As the Ministry stated: "This consultation exercise is intended to help ensure that the legislation gives proper effect to the policy decisions that have been made and to minimise the risk of unintended consequences of change." 431

In its report on the submissions from 2005, ${ }^{432}$ the Ministry of Economic Development noted that it was aware of the implications of some policy issues, such as the abolition of pre-grant opposition, but indicated that it was not intending to reopen the debate. The Ministry stated that "none of the submissions identified any new issues that would warrant reconsidering the policy decision at this stage" ${ }^{433}$ but also that it would nevertheless continue to draw attention to critical policy issues. Furthermore, the Ministry considered assigning the clarification of these matters to a Select Committee. ${ }^{434}$

Boundaries to Patentability, above n 14.

Draft Bill, above n 17.

Frankel, above n 252, 351.

Boundaries to Patentability, above n 14.

Ministry of Economic Development Submissions on Exposure Draft of Patents Bill (Wellington, 2005).

Ibid.

Ibid. 
The intended purposes of the draft bill were, according to clause 3 of the Bill, to: ${ }^{435}$

(a) ensure that a patent is granted for an invention only in appropriate circumstances by-

(i) establishing appropriate criteria for the granting of a patent; and

(ii) providing for procedures that allow the validity of a patent to be tested; and

(b) provide greater certainty for patent owners and the users of patented inventions that patents will be valid after they are granted; and

(c) address Maori concerns relating to the granting of patents for inventions derived from indigenous plants and animals or from Maori traditional knowledge; and

(d) promote quality, expertise, and integrity in the profession of patent attorneys; and

(e) ensure that New Zealand's patent regime takes account of international developments.

In order to achieve these purposes, the Draft Patent Bill proposed fundamental changes for New Zealand's patent legislation. Concerning the grant of a patent, the regulations provided major developments, such as the introduction of absolute novelty, ${ }^{436}$ the revised definition of a patentable innovation $^{437}$ including explicit exclusions from patentability, ${ }^{438}$ and the examinations for obviousness and usefulness. ${ }^{439}$ Another notable element was the establishment of a Maori Advisory Committee to provide advice to the Commissioner of Patents on patent applications for inventions involving indigenous plants and animals. ${ }^{440}$ In addition, the Draft Patents Bill proposed significant changes regarding third-party challenges, such as the abolition of pre-grant opposition and its replacement by re-examination. ${ }^{441}$

Draft Bill, above n17, cl 3 .

Ibid, cls 6 and 8 .

Ibid, cl 13.

Ibid, cls 14 and 15 .

Ibid, cl 58.

Ibid, cls 283-286.

Ibid, cls 88-93. 
In 2008, the Patents Bill was introduced to Parliament. This Bill is still in the legislative process, and it is not known when and in what version it will come into force. ${ }^{442}$

Most of the changes proposed in the Draft Bill have been adopted into the Patents Bill, among them the introduction of stricter examination standards, such as absolute novelty instead of local novelty as the base for prior art, ${ }^{443}$ and the examination for an inventive step. ${ }^{444}$ Also included were the definition of invention ${ }^{445}$ and specific exclusions from patentability, ${ }^{446}$ the required publication of patent applications 18 months from the earliest priority date,${ }^{447}$ the establishment of a Maori Advisory Committee to provide advice to the Commissioner of Patents on patents applications for inventions involving indigenous plants and animals, ${ }^{448}$ and the reform of the patent attorney profession. ${ }^{449}$ The proposed amendments in the Patents Bill 2008 will be examined in more detail below, specifically with regard to the examination procedure and the changes in the third-party instruments.

\section{B Proposed Amendments of the Patents Bill 2008 \\ $1 \quad$ Higher standard of examination}

One of the principle intentions of the Patents Bill 2008 is to streamline the granting procedure, providing stricter standards of examination in order to reduce the number of patents granted to non-inventions. ${ }^{450}$ The changes to the examination standards that follow are the most important factors aimed "Time for an Upgrade? New Bill to Overhaul Patents Regime" www.internationallawoffice.com (accessed 22 March 2010). Patents Bill 2008, cls 6 and 8.

Ibid, cl 60.

Ibid, cl 13 .

Ibid, cls 14-15.

Ibid, cl 72(1)(b).

Ibid, cls 275-278.

Ibid, cls 184-240.

Ibid (Explanatory note), 51. 
at strengthening the quality of New Zealand's patents and promoting the agenda of harmonisation.

(a) Definition of invention and specific exclusions from patentability Under the current Patents Act 1953, patentable invention is defined as: ${ }^{451}$

Any matter of new manufacture the subject of letters patent and grant of privilege within section 6 of the Statute of Monopolies and any method or process of testing applicable to the improvement or control of manufacture; and includes an alleged invention

As aforementioned, the IPONZ is required to give the applicant the benefit of doubt when determining whether an invention is patentable or not. ${ }^{452}$ Additional exclusions from patentability have been developed by the courts and are subject to re-interpretation. ${ }^{453}$ As a result, a frequent criticism of the current patent regime is that uncertainties exist regarding the requirements for a patentable invention and possibly patentable subject matters, especially for new technologies. ${ }^{454}$ These uncertainties and the cost to challenge a patent can result in fewer invalidation procedures and the related negative effects that invalid patents have on the market, such as restraint on competition. ${ }^{455}$ Furthermore, as no other patent regime uses New Zealand's current definition for invention, the case law of other countries can no be longer used as a guide. ${ }^{456}$

Consequently, the Patents Bill 2008 proposes a definition for a patentable invention ${ }^{457}$ and the exclusion of specific subject matters from patentability. ${ }^{458}$ In line with goals of harmonisation, this new definition of

Patents Act 1953, s 2(1).

See $R v$ Patents Appeal Tribunal, ex parte Swift and Co, above $\mathrm{n} 93$.

See citation under $n$ 359-362.

Patents Bill 2008 (Explanatory note), 57.

Ibid, 58 .

Ibid, 57.

Patents Bill 2008, cl 13

Ibid, cl 14-15. 
patentable inventions is similar to the definition under the Australian Patent Act. ${ }^{459}$

The exclusion of specific subject matters has been particularly controversial. As the topic of this dissertation is the changes to New Zealand's patent review system and not the entire Patents Bill, this debate cannot be explained in detail. Most heavily criticised, however, were the facts that patents for creative works such as software were not excluded ${ }^{460}$ and that the proposed exclusions regarding methods of medical treatment of humans were not clear enough. ${ }^{461}$

\section{(b) Examination of obviousness and usefulness}

Under the current patent system, applications are only examined for novelty; obviousness can only be a ground for an opposition or revocation procedure. ${ }^{462}$ As a result, New Zealand may grant much broader patents for an invention than countries that examine patent applications for obviousness (as most countries do). ${ }^{463}$ Therefore, with regard to the negative effects of overly broad patents and to the harmonisation agenda, ${ }^{464}$ the Patents Bill 2008 proposes that patent applications be examined to determine whether or not they involve an inventive step. ${ }^{465}$

This change is critical. First, the examination of novelty is straightforward: all features must already exist in the prior art for a patent to be denied. In contrast, the examination of obviousness is much more subjective: the examiner needs to consider whether hindsight is enough to decide that the invention was obvious at the priority date. For this reason,

Patents Act 1990 (Cth), s 18(1).

See, for example, Information Science Department University of Otago "Submission on the Patents Bill 235-1" www.waitaki.otago.ac.nz (accessed 22 March 2010); New Zealand Open Source Society "Submission on Patents Bill - Government Bill 235-1" www.nzoss.org.nz (accessed 20 March 2010), InternetNZ "Submission to the Commerce Committee on the Patents Bill (235-1)" www.isocnz.org.nz (accessed 20 March 2010).

See, for example, Researched Medicines Industry Association of New Zealand Incorporated "Submission on Patents Bill to the Commerce Select Committee" www.ramianz.org.nz (accessed 20 March 2010).

Patents Act 1953, ss 13, 21(1)(e), 41(1)(f) and 42(1).

Patents Bill 2008 (Explanatory note), 52.

Ibid, 54 .

Patents Bill 2008, cl 13. 
different tests (such as the Windsurfing test ${ }^{466}$ ) have been developed to help the examiner decide whether an invention is obvious or not. However, the examination for obviousness may increase the time and effort needed and therefore has the potential to overburden the resources of the IPONZ. Secondly, as discussed in detail above, New Zealand case law currently tests obviousness in a different manner than other jurisdictions. ${ }^{467}$ Thus, it is questionable whether the examination of obviousness by the examiner would actually harmonise New Zealand's laws with the laws of its important trading partners, when the outcome of such an examination might be not the same.

In addition, patent applications will also be examined for usefulness by the examiner. ${ }^{468}$ This is particularly relevant for patents with subject matters in new technological fields. For example, under the current system, some patents have been granted involving large numbers of gene sequences, even though it is not clear what the use of these sequences might be. ${ }^{469}$ Researchers nevertheless have to pay royalties if they want to use these gene sequences in their projects, a possible restraint on further innovations. Usefulness is a requirement for a patentable invention in most other patent regimes, ${ }^{470}$ and therefore the examination for usefulness is a step toward harmonisation with important trading partners such as Australia. ${ }^{471}$

(c) Absolute novelty standard

Additionally, according to clause 8 of the Patents Bill 2008, the relevant prior art base includes all material available to the public (whether in New Zealand or elsewhere) by description (written or oral) in use before the priority date. With this clause, the Patents Bill 2008 proposes an absolute novelty standard to replace the local novelty standard. This means that New Zealand would adopt an internationally recognised standard of

Windsurfing above n 343.

See Peterson, above n 314.

Patents Bill 2008, cl 13.

Ibid (Explanatory note), 62.

See TRIPS, above n 5, art 27.

Patents Act 1990 (Cth), s 18(1)(c). 
novelty, a further step in harmonising its law with important partners in trade. ${ }^{472}$ As more prior art will be available to challenge the grant of a patent than under the current system, it seems likely that fewer undesirable patents will be granted or will survive in the market.

\section{(d) Balance of probabilities}

In determining whether or not an application should be granted, the IPONZ must currently give the benefit of doubt to the applicant. As explained above, this approach means that the examiner can only refuse an application if he or she is certain that the court would find this patent invalid. ${ }^{473}$ As a result, patents of uncertain validity may be granted. ${ }^{474}$ This uncertainty in the quality of patents lowers their value, and invalid patents may remain in the market if no third party challenges them, ${ }^{475}$ possibly leading to higher prices and restricted competition at the expense of society. ${ }^{476}$

According to the Patents Bill 2008, instead of the former benefit-ofdoubt requirement, the Commissioner must now accept the complete specification on the more lenient standard of "balance of probabilities". 477 The Commissioner will thus have a broader justification for refusing the grant of patents of doubtful validity, allowing the overall quality of New Zealand's patents to increase. If patents are only granted if they meet all requirements of the law at the balance of probabilities standard, it will be more likely that the patents will be valid. ${ }^{478}$ It is also in the interest of the patentee to have strong patents that would survive a challenge.

See, for example, Patents Act 1990 (Cth), sch 1.

See $R v$ Patents Appeal Tribunal, ex parte Swift and Co, above $\mathrm{n} 93$.

Patents Bill 2008, (Explanatory note), 58.

See Chris Dent, above n 100, 382.

Patents Bill 2008, (Explanatory note), 58.

Ibid, cl 70.

Ibid, (Explanatory note), 60. 
The second key objective of the Patents Bill 2008 is to provide instruments that will make it easier and cheaper to challenge the grant of a patent. ${ }^{479}$ The following third-party instruments are proposed:

(a) Third-party assertion

(i) Background

The current Patents Act 1953 provides no time limit for the publication of an application. An application will be published after acceptance, which in New Zealand generally takes two to four years after the initial application is filed. ${ }^{480}$ With the Patents Bill 2008, New Zealand adopts the automatic publication of the specification after 18 months. ${ }^{481}$ Furthermore, the Bill provides that all examiner reports and communication will be open for public inspection once the application has been accepted. ${ }^{482}$ This allows third parties to make assertions; these are similar to existing submitting instruments, such as the European Union's third-party observation. ${ }^{483}$

(ii) How does the instrument work?

The Patents Bill 2008 introduces a new third-party instrument called 'assertion'. This instrument allows any person to assert to the Commissioner that the invention claimed in the patent application is not patentable due to its lack of novelty or its obviousness. ${ }^{484}$

The person asserting to the Commissioner must state his or her reasons for the assertion by filing a notice. ${ }^{485}$ Additionally, it is apparently permissible to submit documents accompanying the notice, as clause 86(3) of the Patents Bill 2008 states that the notice and "any documents

Ibid, 50.

Ibid, 9.

Ibid, cl 72(1)(b).

Ibid, cl 74.

Ibid, cl 86, 87.

Ibid.

Ibid, cl 86(2). 
accompanying" shall be open to the public. ${ }^{486}$ In response, the Commissioner must inform the applicant that a notice has been filed. ${ }^{487}$

(iii) Analysis

This new informal instrument of assertion allows third parties to notify the Commissioner before acceptance of the application in matters affecting novelty and obviousness. As third parties will be allowed to file relevant prior art documents at an early stage of the examination process of the application, the IPONZ may thereby become aware of more substantial prior art before the examination procedure has been completed. Unfortunately, it is not clear whether or not third parties will be allowed to respond to the applicant's statements. It is additionally unclear whether the Commissioner will have the right to ignore the submitted prior art information. Currently, it seems that the assertion procedure only allows for the submission of documents and a notice explaining why the person is asserting a claim. It is my opinion that the assertion instrument is a first step in the right direction, but it needs to be described in greater detail.

\section{(b) Re-examination}

(i) Background

The Patents Bill 2008 repeals pre-grant opposition under section 21 of the Patents Act 1953 and replaces it with a re-examination instrument. ${ }^{488}$

(ii) How does the instrument work?

This new procedure allows any person to request a re-examination, after publication of the application but before a patent is granted. ${ }^{489}$ The 
grounds for re-examination are limited to novelty and obviousness. ${ }^{490}$ All other grounds of the current opposition procedure are no longer available.

"Any person" means that anybody, including the applicant him- or herself, can request re-examination and "standing", as in the current opposition procedure, is no longer required.

If somebody requests re-examination, the Commissioner must reexamine the application. ${ }^{491}$ It is also possible for the Commissioner to reexamine an application without a request of a third party at any date after publication but before the grant of a patent. ${ }^{492}$

After the grant of a patent, a request for re-examination is possible for any person, as long as no relevant proceeding is pending and no application for revocation by the Commissioner has been made. ${ }^{493}$ Additionally, the Commissioner must re-examine the patent if its validity is in dispute and a re-examination has been ordered by the court. ${ }^{494}$

A request for re-examination obliges the Commissioner to consider and to report to the best of his or her knowledge whether or not the complete specification is novel and involves an inventive step. ${ }^{495}$

If the Commissioner decides that the complete specification is not novel or does not involve an inventive step, and that the applicant/patentee has not properly amended the specification, the Commissioner may refuse the grant of a patent by re-examination before the grant of a patent. ${ }^{496} \mathrm{He}$ or she may also revoke the patent by re-examination after granting. ${ }^{497}$

(iii) Analysis

By replacing pre-grant opposition with pre-grant re-examination, the Patents Bill 2008 shifts the burden to prove the patentability of an

Ibid, cl 90(1).

Ibid, cl 88(1).

Ibid.

Ibid, cl 89(1) and (2).

Ibid, cl 89(5).

Ibid, cl 90(1).

Ibid, cl 91(1).

Ibid, cl 92(2). 
application in the first stage of examination back to the IPONZ. As a result, third parties are no longer allowed to directly influence the pre-grant patent procedure.

The main argument for repealing the pre-grant opposition procedure is that it has the potential to delay the grant of a patent for years. ${ }^{498}$ It is true that pre-grant opposition, as currently implemented in New Zealand, has the potential to delay the patent-granting procedure. However, the efficiency of re-examination procedures can also be questionable, because it strongly depends on the instrument's design and utilisation. ${ }^{499}$

The clauses in the Patents Bill 2008 regulating the re-examination procedure are not very specific concerning the influence that third parties are allowed. For example, it is unclear whether third parties have the right to submit prior art or statements.

Furthermore, the Patents Bill does not currently provide for a hearing after the Commissioner's determination and report on whether the invention is novel and involves an inventive step.

Overall, the current pre-grant opposition provides third parties with much more influence on the procedure than they will have after the Patents Bill 2008 passes.

In addition, the Patents Bill is also vague as to how the proposed reexamination procedure will work in conjunction with revocation by the Commissioner. It seems that the Patents Bill 2008 will allow two administrative post-grant procedures at the same time.

However, an argument in favour of the re-examination procedure is that it provides a more inexpensive and easier way to challenge the validity of a patent. ${ }^{500}$ However, even if the re-examination procedure is cheaper, it will not accelerate the removal of undesirable patents from the register if it turns out to be less effective for third-party challengers. 
(d) Revocation

(i) Background

As compensation for the abolition of pre-grant opposition, the Patents Bill 2008 provides third parties with an expanded revocation procedure before the Commissioner. ${ }^{501}$ The provisions for revocation by the Commissioner and for revocation by the courts are now combined in clause 104. The revocation instrument by the courts is principally the same as before, very much similar to the revocation procedure according to section 42 of the Patents Act 1953. In the following section, foremost the changes with respect to revocation by the Commissioner will be analysed.

(ii) How does this instrument works?

The revocation instrument allows third parties to apply for revocation by the Commissioner at any time during the term of a patent on any of the grounds on which a grant can be refused. ${ }^{502}$ In contrast to the re-examination procedure, the revocation procedure includes a hearing of the parties before the Commissioner issues his or her decision. ${ }^{503}$

(iii) Analysis

The more comprehensive revocation procedure by the Commissioner, the new alternative offered by the Patents Bill, is expected to be an inexpensive and quick procedure in comparison to the more tedious and time-consuming revocation by the High Court under the current system. ${ }^{504}$ However, under the new Patents Bill, third parties still have the right to apply directly to the High Court if they wish to do so. ${ }^{505}$

Patents Bill 2008, cl 104.

Ibid, cl 106(1).

Ibid, cl 105(3)(b).

Ibid (Explanatory note) 8 .

Ibid. 


\section{(e) Māori Advisory Committee}

With the Māori Advisory Committee, the Patents Bill 2008 provides a new instrument for a specific third party. ${ }^{506}$ It requires the Commissioner to consider advice from the Māori Advisory Committee concerning patent applications involving Māori traditional knowledge and indigenous plants and animals. Although the advice of the Māori Advisory Committee is not binding, it should help limit the inappropriate grant of patents for inventions that are based on traditional knowledge. ${ }^{507}$

\section{Are the Amendments of the Patents Bill 2008 an Appropriate Solution for New Zealand?}

After examining in detail the amendments proposed by the Patents Bill 2008, the question is now whether these amendments are the best solution for New Zealand. By adopting these changes, will New Zealand achieve the goals of its patent policy and enhance the quality of its patents?

\section{$1 \quad$ Changes in the standards of examination}

As critically discussed above, New Zealand's standards of examination are currently lower than those of other countries. In order to align New Zealand's standards of examination with international standards, the Patents Bill 2008 provides and implements new instruments and procedures to harmonise the national examination standards with those of important trade partners, Australia in particular. ${ }^{508}$

While this development is advantageous for New Zealand, it also should be noted that these new examination standards have the potential to delay the grant of a patent and may impose extra costs. ${ }^{509}$ For instance, examiners will now be forced to examine applications for obviousness and usefulness on an absolute novelty standard. This means that the prior art

Patents Bill 2008, cl 276.

Ibid (Explanatory note), 65-68.

Most of the changes in the examination procedure are based on the law of Australia, see provisions of the Patents Bill 2008 and of the Patents Act 1990 (Cth).

Patents Bill 2008, (Explanatory note), 60. 
search will take more time and the examination, although thorough, will be more challenging for the examiner. ${ }^{510}$ However, the delays and costs will decrease over time, as IPONZ and the applicants become more familiar with the new examination standards. ${ }^{511}$

In the end, using the new stricter examination standards will enhance the overall quality of patents, and this is therefore a good solution for New Zealand. However, it would be preferable and more effective to combine the stricter examination standards with new instruments for third parties, allowing them greater influence on the procedure as a whole. The support of third parties (for example, in the submission of information on relevant prior art) might help prevent the IPONZ from overburdening its resources, which could result in delayed examinations.

\section{New third-party instruments}

\section{(a) Assertion}

As analysed above, the assertion instrument is the cheapest and best solution to support the IPONZ's examinations. By allowing third parties to submit relevant prior art at the examination stage, more relevant documents are available to decide whether an invention is patentable or not. ${ }^{512}$ The third parties will be allowed to file statements explaining the relevance of these documents. ${ }^{513}$ Furthermore, this instrument causes no significant delays, as the Commissioner considers the filed notice but is not impeded by direct influence of the third parties. ${ }^{514}$

Consequently, the assertion instrument is a good solution to increase the prior art information available for the IPONZ without increasing the costs to the third party and without causing delays in the procedure. 


\section{(b) Re-examination}

The shifting of the Patents Bill 2008 to a more inquisitorial approach with respect to pre-grant instruments can be criticised on several points. Specifically, the reasoning behind replacing the pre-grant opposition system with a re-examination procedure can be disproved.

The main argument in favour of a re-examination procedure is that third parties will have the chance to encourage the IPONZ to re-examine an application that may lack patentability, without risking the costs of an opposition procedure. ${ }^{515}$ It is likely that an opposition procedure would be more expensive than a re-examination procedure. ${ }^{516}$ The main reason for this is that the third party in an opposition procedure has the burden to prove that the application is not patentable. This means that an in-depth search for prior art must be carried out before an opposition can be filed. Furthermore, the third party must file several written statements and prepare for an oral hearing to demonstrate why the submitted prior art is relevant to the patentability of the application. However, by implementing the additional instrument of assertion, a third party that would prefer to avoid the cost of an opposition procedure now also has the option to submit documents to the examiner without any extra costs.

It has been further argued that "the abolition of the existing pre-grant opposition procedure will remove a potential source of costs and delay in obtaining a patent." ${ }^{, 517}$ It is generally true that pre-grant opposition has the potential to delay the grant of a patent. However, if the challenge of the application is reasonable, the delay caused by pre-grant opposition is acceptable, as the grant of an invalid patent may cause significant problems. Furthermore, if the application survives an opposition procedure, its worth may increase, to the applicant's advantage. The delays that may be caused by opposition aimed at putting off the grant of a patent as long as possible can be reduced if the pre-grant opposition system is designed in a way that 
limits delaying effects. Examples for limitations could be, for instance, strict deadlines and limited grounds for opposition.

An additional issue is that the re-examination procedure is only based on two grounds: novelty and obviousness. The Commissioner cannot consider, for example, the prior use of an invention in this procedure. Therefore, a patent may be granted which will later be ruled as invalid in the courts. ${ }^{518}$ Re-examination also shifts the burden to find and analyse prior art lies to the IPONZ, since third parties are not allowed to submit statements. ${ }^{519}$ Third parties may thus be forced to challenge a patent after the grant, risking infringement actions. ${ }^{520}$ In this permutation, with a validity procedure and an infringement action pending simultaneously, a fair number of parties may decide to resolve the conflict outside the courts in a settlement agreement, with the result that an invalid patent might remain in the register.

Moreover, as more than 90 percent of New Zealand's patents are granted to overseas applicants and most of the benefits of invalid patents flow overseas, it may be desirable to provide a review system that allows third parties an early and strong influence in the granting procedure, as the re-examination procedure provides. As the New Zealand Law Society said "a pre-grant opposition procedure for third parties (as under the 1953 Act) would result in a cleaner and more reliable register." ${ }^{521}$

The IPONZ has only limited resources of time, money, and specialized personnel. Consequently, particularly in new technological fields, the prior art brought to them within an opposition procedure may support the examiners better than the art for a re-examination procedure, because only in the context of an opposition procedure is it permissible to submit prior art that is not in published form. ${ }^{522}$

Liz Nock "Update on New Zealand's Patents Bill" www.ajpark.com (accessed 15 March 2010).

Patents Bill 2008, cl 88-90.

Opinion from Patent Law Firm A J Parks, see above n 12, 2902.

New Zealand Law Society "Submission to the Patents Bill" www.lawsociety.org.nz (accessed 20 March 2010).

522

Patents Act 1953, s 96(1). 
These critical issues and partial disadvantages of the re-examination system present a picture that implies that the re-examination procedure may not be the best solution for New Zealand.

\section{(c) Revocation}

The new extended revocation procedure before the Commissioner is a good way to allow third parties to challenge the validity of a patent on all grounds available in a less expensive administrative procedure. The IPONZ has the experience and technological knowledge to comprehensively review an invention's patentability. Revocation is possible as an administrative procedure, which would be less expensive and time-consuming than a revocation before the High Court. ${ }^{523}$ However, if third parties want to go directly to the High Court, they have the right to do so. ${ }^{524}$ Therefore, the extension of grounds available through revocation by the Commissioner is a good solution to enhance the quality of New Zealand's patents.

\section{SUGGESTED ROUTE FORWARD FOR NEW ZEALAND}

\section{A Developing a New Approach for the New Zealand Review System}

Should New Zealand implement the Patents Bill 2008, the outlined changes will set New Zealand's patent system on the right path, in line with international standards. However, shifting from a pre-grant opposition procedure to a pre-grant re-examination procedure will have enormous impact on the entire patent system, which may not be the best solution for New Zealand. In consideration of the particular needs of the country, this dissertation aims to develop a new approach that may be more advantageous for New Zealand. 


\section{B Framework of a New Approach}

In order to develop a new approach for New Zealand's review system, it is first necessary to define the framework. It is particularly important to keep the country's needs in mind.

The most important issues that require consideration in developing a new approach for New Zealand are the following:

\section{$1 \quad$ International framework for a patent reviewing system}

In general, intellectual property rights are local or territorial rights. This means that a patent sealed and registered in New Zealand only grants protection within the territory of New Zealand and can only be enforced within this jurisdiction. ${ }^{525}$ In this respect, the patent law of New Zealand is a domestic law. However, ongoing globalisation and international trade have led to new considerations for the territorial nature of intellectual property law. Therefore, in developing a new approach in its patent law, New Zealand also needs to consider the international developments with regard to patent law harmonisation, in order to minimize differences that may impede its international trade. Furthermore, the new patent law needs to be consistent with New Zealand's obligations to international agreements. The following international agreements require consideration:

(a) Paris Convention for the Protection of Industrial Property, 20 March 1883

New Zealand has been a member of the International Union for the Protection of Industrial Property since 1931. The purpose of the Convention is to enable the transfer of knowledge and to increase international trade by harmonising industrial property law between its member states. ${ }^{526}$ The Convention enumerates details such as national treatment, the right of priority, and rules related to local manufacture; it includes the concept of the 
national independence of patent systems. ${ }^{527}$ However, the Convention makes no reference to patent review systems.

(b) Patent Cooperation Treaty (PCT), 19 June 1970

The Patent Cooperation Treaty simplifies the procedure of filing a patent application internationally and reduces its cost. It enables the filing of a single patent application ("international application") with one Patent Office ("receiving office") to have effect in each member state nominated by the applicant. This one application is examined by the receiving office for formal requirements and researched with respect to available international prior art. The applicant then has the opportunity to convert the international application into a national application ("the national phase"). The PCT has been in force in New Zealand since December 1992. ${ }^{528}$

The Patent Cooperation Treaty only governs the system of international patent applications; no provisions with respect to patent review systems are included.

(c) Patent Law Treaty (PLT), June 2000

The Patent Law Treaty, enacted by the WIPO in 2000, is one of the more recent treaties regarding the harmonisation of patent law. ${ }^{529}$ Its purpose is to streamline the application procedure and to reduce the cost of obtaining parallel patents in several countries. ${ }^{530}$ New Zealand is not yet a member nation, but Australia signed the treaty on 16 December 2008. Therefore, New Zealand might also consider becoming a member of the Patent Law Treaty.

The PLT includes some details regarding patent review systems. For example, the PLT states that non-compliance with certain formal requirements concerning the application may not be a ground for the

Paris Convention for the Protection of Industrial Property, above n 526.

WIPO List of Treaties www.wipo.int

Patent Law Treaty, above n 108.

WIPO Intellectual Property Handbook: Policy, Law and Use (2 ed, WIPO Publication No. 489 (E), Geneva, 2004) 1.16. 
revocation or invalidity of a patent. ${ }^{531}$ However, some non-compliance can be used as a ground to challenge a patent, if it is the result of a fraudulent intention. Furthermore, the PLT also prohibits the revocation or invalidation of a patent without giving the patentee the opportunity to attend the revocation and to amend or correct the patent. ${ }^{532}$

Thus, the PLT needs to be considered if grounds for revocation or invalidity procedures are developed that are based on the formal requirements for the application of a patent.

\section{(d) TRIPS Agreement}

The Agreement on Trade-Related Intellectual Property Rights (TRIPS) was signed in 1994 as an addition to the Agreement establishing the World Trade Organisation (WTO) ${ }^{533}$ It aims to develop an international framework of principles and rules dealing with the global trade of pirated and counterfeit goods. ${ }^{534}$ Its provisions afford member states with a minimum standard of protection, the principle of national treatment, the principle of most-favoured-nation treatment, and the World Trade Organisation Dispute Settlement Mechanisms. New Zealand is a member of TRIPS.

The TRIPS Agreements must be considered when implementing a review system, because if member nations implement administrative revocation and inter partes procedures (such as opposition, revocation, or cancellation), these procedures have to follow the general principles set out in Articles 41.2 and 3. ${ }^{535}$ These include the precepts that the enforcement of intellectual property rights should be fair and equitable, should not be complicated or expensive, and should not entail unreasonable time limits or delays. ${ }^{536}$ Furthermore, the decision of the Patent Office (preferably in

Patent Law Treaty 39 ILM 1047, 1058 (2000), art 10(1). Ibid, art 10(2).

Michael Blakeney Trade Related Aspects of Intellectual Property Rights: A Concise Guide to the TRIPs Agreement (Sweet \& Maxwell, London, 1996).

Ibid.

TRIPS, above n 5, art 62(4).

Ibid, art 41(2). 
written form) must be reasonable, without delay, and based only on evidence on which the parties have the opportunity to be heard. ${ }^{537}$ Finally, the ultimate decision in an administrative procedure shall be subject to an appeal to the court or to other judicial authorities. ${ }^{538}$

\section{(e) Result}

As shown above, the worldwide harmonisation agenda does not provide explicit provisions concerning the type of third-party instruments a patent regime should have. Only the TRIPS Agreement regulates that if a member state provides third-party instruments, their work and interaction should be governed by general principles such as fairness, equality, simplicity, low costs, and limited delays. Explicit specifications of how the third-party instruments should be designed are not provided.

\section{$2 \quad$ Harmonisation with important trade partners}

\section{(a) Australia}

Australia is one of the most important trading partners of New Zealand. ${ }^{539}$ The two countries are close partners territorially and benefit from several agreements meant to stimulate and to simplify their crossnational trading activity. Most of these agreements include general regulations concerning harmonisation; only those agreements that refer to the harmonisation of intellectual property law will be considered below. 
(i) Australia-New Zealand Closer Economic Relations Trade Agreement (ANCERTA)

ANCERTA, more popularly known as the CER Agreement, is a series of agreements and arrangements that provides a free trade area, eliminating most of the barriers to trade between Australia and New Zealand. ${ }^{540}$

One of the key aspects of the CER Agreement is the mutual recognition of goods and services between Australia and New Zealand. Under the Trans-Tasman Mutual Recognition Arrangement (TTMRA), the countries agreed that goods legally sold in one country can also be sold in the other country without any further restrictions; additionally, people registered to practise an occupation in one country are allowed to practise in the other country as well.

Unfortunately, the sale of goods protected by intellectual property rights is not included under TTMRA. ${ }^{541}$ However, this agreement is important for patent law because registered patent attorneys from one country are permitted to apply for registration in the other country. ${ }^{542}$

(ii) Memorandum of Understanding between the Government of New Zealand and the Government of Australia on Coordination of Business Law 2006

In 2006, the Minister of Commerce of New Zealand and the Treasurer of the Commonwealth of Australia signed the current Trans-Tasman Memorandum of Understanding for Coordination of Business Law. This Memorandum includes the proposed work program for the harmonisation of the business laws of the two countries by 2011. Its Annex (Work 
Programme for Coordination of Business Law) includes the following purpose: ${ }^{543}$
j) Development of a seamless processing regime for the granting of patents and the registration of trade marks, plant variety (or breeders') rights and patent attorneys ...
(Emphasis added)

(iii) ASEAN-Australia-New Zealand Free Trade Area (AANZFTA)

The latest development in the harmonisation process of intellectual property law between New Zealand and Australia is the establishment of the Australia-New Zealand Free Trade Area (ASEAN). The aim of the ASEANAustralia-New Zealand Free Trade Bill is to implement the Agreement establishing the ASEAN-Australia-New Zealand Free Trade Area (AANZFTA) on 27 February 2009. ${ }^{54}$ The AANZFTA deals with intellectual property law in chapter 13 of the Agreement. ${ }^{545}$ The parties agreed under article 9(7) of chapter 13 of the Agreement that they would accede to several international treaties dealing with patent law. New Zealand is a member of most of these treaties; however, under this agreement, New Zealand is obligated to join the Patent Law Treaty 2000.

\section{(b) Europe}

The European Union is New Zealand's second most important market after Australia, accounting for approximately 12.8 percent of the total

Memorandum of Understanding between the Government of Australia and the Government of New Zealand in Coordination of Business Law 2006, www.treasury.gov.au (accessed 5 November 2009) (emphasis added). November 2009).

Each Party confirms its commitment to reducing impediments to trade and investment by promoting deeper economic integration through effective and adequate creation, utilisation, protection and enforcement of intellectual property rights, taking into account the different levels of economic development and capacity and differences in national legal systems and the need to maintain an appropriate balance between the rights of intellectual property owners and the legitimate interests of users in subject matter protected by intellectual property rights. 
exports of New Zealand. ${ }^{546}$ In 2007, New Zealand and the European Union signed the Joint Declaration on Relations and Cooperation between the European Union and New Zealand 2007. ${ }^{547}$ More specific bilateral agreements concerning patent law do not exist between New Zealand and the European Union.

\section{(c) Result}

The harmonisation effort with important trading partners is one aspect of patent policy in New Zealand. In particular, Australia and New Zealand are attempting to harmonise their patent laws, but at present all of these approaches are limited to questions regarding the grant of patents, not the review system.

However, the design of the review system should also be harmonised in order to allow the same conditions in the two countries. Even though the amendments proposed by the Patents Bill 2008 are primarily based on the existing patent law of Australia, some significant differences still exist. For example, Australia still has pre-grant opposition as a third-party instrument, which is slated to be abolished in New Zealand. Accordingly, the issue arises of how New Zealand and Australia will be able to share examination of patents when the two countries do not provide the same kinds of influence for third parties in the patent-reviewing procedure. The design of a new review system could be based on the review system under the Australian patent regime.

Even if most research relating to third-party instruments is based on the European patent system and the patent system of the United States, and although both systems provide well-established instruments, the needs of New Zealand are more comparable those of Australia. Both countries are small economies and strongly dependant on international trade; in addition, the patent system of both countries is based on the laws of the United Kingdom, and the two countries have similar domestic issues, including the 
rights of their indigenous peoples. It may therefore be desirable to utilise the already existing knowledge of specific types of third-party instruments and the review system of Australia, adjusting it to fit the particular needs of New Zealand in order to design a new review system for the country.

\section{The New Approach - Third-Party Instruments for New Zealand}

According to the analysis of the Patents Bill 2008, the new approach will adjust the proposed amendments so that the former, more adversarial approach of the current Patents Act 1953 will be retained. The proposed adversarial approach would also conform with the harmonisation agenda, at least with respect to Australia.

The new approach highlights the fact that an optimal system for New Zealand requires adjustments to the influence of third parties at the stage before a patent is granted. Therefore, the following instruments could be appropriate for a patent review system in New Zealand:

$1 \quad$ Assertion by any third party after publication of the specification on all questions of patentability

As analysed above, the assertion instrument provides an effective and inexpensive way for a third party to support the IPONZ at the examination stage without becoming a party of the procedure.

The instrument of assertion should also allow third parties to submit relevant material to the IPONZ. A statement providing the reason why the submitted material is relevant should accompany the submission. As in the European system, it should be possible to make a submission anonymously. Furthermore, the third party should have the right to respond to the applicant's replies.

To effectively support the examiner in the examination process, the assertion instrument should allow all grounds of patentability. 
Pre-grant opposition on the grounds of novelty and obviousness

If third parties wish to participate more actively in the examination procedure, they should also have the right to oppose the application. Such pre-grant opposition would also allow third parties to carry out an in-depth argumentation on relevant documents in submission and in hearings before the examiner. As the right to opposition gives third parties a strong influence, which they could use to delay the granting procedure, the grounds should be limited to novelty and obviousness.

Allowing pre-grant opposition of applications offers several advantages for New Zealand. As invalid patents create social costs and New Zealand mainly grants patent to non-residents, it would be better to be able to challenge a patent before it is granted. Otherwise, a patent may remain in the register without being challenged, because of the risk of lawsuits.

The possible delaying effects of pre-grant opposition can be reduced by implementing strict deadlines. In addition, as third parties would have to bear the costs of an opposition procedure, they would use substantial prior art during opposition that may also reduce the time of such a procedure.

\section{Revocation before the Commissioner and the Court without limited grounds}

The final instrument would be the revocation on all grounds of patentability before the Commissioner and the courts after grant of the patent. The post-grant revocation instrument should be retained, as more grounds are available than in pre-grant opposition. Furthermore, after a grant, new documents may be found to challenge an application. Since a procedure before the Commissioner is financially easier to bear than a procedure in the courts, the revocation should also be possible in an administrative procedure without limited grounds.

\section{CONCLUSION}

A patent is a temporarily limited monopoly on an invention giving the patentee the right to exploit this invention and to prohibit its use by others. 
In return, the patentee provides a description of the invention, which allows anybody to use it after the expiration of the patent term. Even though patents limit competition and may result in higher prices, they may also help to encourage research and development and to promote innovation. This societal benefit is the main reason for countries to provide patent protection. However, the balance between advantages and disadvantages of patents for society is at risk if too many inventions that are not patentable obtain patent protection, or if overly broad patents are granted. Such "bad" patents impose costs on society without a beneficial effect on research and development. Providing for strong patent rights is the best solution to maintain this balance.

As the quality of patents greatly depends on the quality of the examination procedure, it would be ideal for a country to have an effective and inexhaustible pool of experts and resources for each kind of industry to examine its patent applications. Unfortunately, no country in the world has such an ideal patent office. In practise, patent examiners have only a limited amount of time to conduct prior art searches and make decisions about the patentability of applications.

This means that the quality of patents must be improved by another factor: third parties, whose influence can help to prevent the grant of patents that should not be granted and to eliminate "bad" patents, should they be in the market. Third parties should therefore have a key role in the granting procedure. As a result, the quality of patents would improve, innovation would be encouraged, and society would receive benefits from its patent system. As a fair patent system needs to balance the interests of all concerned, it should also provide third parties with instruments to influence the granting procedure to protect them against the unfair use of patents. Third parties need to know whether and when something happens that could affect their business. Although the patent system is not designed to give patentees weapons to harass their business competitors, it still gives the patentee a competitive advantage. In order to keep the balance, a good patent system should therefore allow third parties to influence the granting procedure. 
Patent systems worldwide provide several instruments for third parties to participate in the granting procedure with different levels of influence and at different stages of the administrative procedure. How much influence a third party has depends strongly on the quality of the examination procedure.

The most effective way to review patents is before the courts, as it is the function of the courts to make a final determination of whether a patent is valid or not. Unfortunately, patent litigation is expensive and timeconsuming. Although patents are supposed to protect small firms, these firms can in fact be crushed by the cost of patent litigation. Therefore, most patent regimes also provide reviewing procedures before the patent office. As analysed above, the most effective review instruments, such as opposition, are adversarial proceedings. Comparable to court proceedings, the burden of proof lies on the opponent, who must file substantial evidence to be successful. Such a review procedure imposes costs and delays into the proceedings. Additionally, if a comprehensive review of a patent is only allowed after the patent is granted, the third party faces the risk of being sued in a parallel infringement action. As a result, it is quite likely that invalid patents survive in the market because it is too expensive and too risky to challenge them.

Another issue is the quality of the patents granted by the patent office. If the standards of examination are high and the patent office refuses all undesirable applications, it may not be necessary for third parties to have numerous possibilities to challenge the grant of a patent. Thus, the better the examination procedure of the patent office, the lower the influence of third parties needs to be. In other words, if the examination procedure already creates strong patents, it will not be necessary to give third parties much influence in the granting procedure.

Under current New Zealand patent law, due to its less than strict examination standards, it is relatively easy to obtain patents with an overly broad scope. The existing law accordingly provides third parties with pregrant opposition, giving them a strong influence before the patent is even granted. In order to clear "bad" patents out of the register, third parties are 
allowed to challenge applications on several grounds without risking lawsuits. This approach seems beneficial for third parties, but is disadvantageous for patentees, who must bear the risk that the grant of a patent may be delayed for years. On the other hand, the influence of third parties on the examination itself is not as strong it might first appear. Firstly, third parties can only have full access to the information of an application after the examination has already been carried out. This means that the patent office reaches the point of granting a patent without any influence by third parties. Furthermore, a third party who may have relevant material on the patentability of an application has to bear the costs of an opposition procedure because no other instrument (such as assertion) currently exists. Thus, material relevant to the patentability might not be submitted and the application might not be challenged at all. Moreover, the timeframe for opposing an application is strictly limited to three months after the third party had its first access to the complete specification. Therefore, an opposition may be unsuccessful because the time for in-depth research for prior art was too short.

Overall, it may be easy to obtain a patent in New Zealand with a broad scope, but at the same time, the law also provides third parties with strong instruments to challenge these patents in order to maintain a balance.

Under the Patents Bill 2008, the examination procedure will be much stricter. The instruments for third parties to challenge the grant of a patent will significantly change. With the establishment of an automatic publication of the specification, as well as the instruments of assertion and re-examination, third parties will be given the opportunity to exert influence much earlier than before. Particularly, the right to give notice to the Commissioner and to submit relevant material gives third parties new possibilities to exert influence without filing an opposition. However, neither instrument allows direct participation in the proceedings, which has advantages and disadvantages. Furthermore, the revocation procedure before the Commissioner, which currently gives the third party more influence, would only be allowed after the grant of a patent and would involve the risk of being sued. Under the Patents Bill 2008, the Patent 
Office must apply stricter standards for examination, but third parties would have less direct influence before the grant of a patent.

Neither the approach of the Patents Act 1953 nor that of the Patents Bill 2008 is the ideal solution for New Zealand's review system. However, a mixture combining both approaches may be more appropriate in order to achieve the goal of avoiding as many "bad" patents as possible in the register. The revised patent law will increase the standard of examination, but it would still be better for New Zealand's system to offer third parties more involvement in the examination procedure than the Patents Bill proposes. As it is currently formatted, the extended prior art base of absolute novelty, the examination for obviousness, and the changed standard of proof have the potential to overload the resources of the New Zealand patent office. In addition, the fact that third parties may have a better perspective on prior art and could help prevent invalid patents during the examination procedure has thus far been overlooked. An earlier influence of third parties could speed up the examination process in more ways than one, if relevant prior art were brought to light or submitted to the Commissioner before he or she carries out the examination.

A new approach, as suggested above, incorporating elements of both schemes should also be considered as a way to enhance the quality of New Zealand's patents while keeping New Zealand's patent system in balance. 


\section{BIBLIOGRAPHY}

\section{Texts and articles}

Adelman, Martin J "Property Rights Theory and Patent - Antitrust: The Role of Compulsory Licensing" (1977) 52 New York University Law Review 977.

Arrow, Kenneth J "Economic Welfare and the Allocation of Resources for Invention" (1959) Economic Division of the RAND Corporation, Paper P-1856-RC, 9.

AIPLA Report of the Economic Survey (AIPLA, Washington, 2009).

Barfield, Claude and Calfee, John E Biotechnology and the Patent System: Balancing Innovation and Property Rights (The AEI Press, Washington D.C., 2007).

Blakeney, Michael Trade Related Aspects of Intellectual Property Rights: A Concise Guide to the TRIPs Agreement (Sweet \& Maxwell, London, 1996).

Blijlevens, Anton "What is obvious may not seem obvious: Obviousness in New Zealand and Australia" (2008) 5 New Zealand Intellectual Property Journal 425.

Blum, Jeremy "Why 'Inventions' Should by Removed from New Zealand Patent Law" (2006) 64 Intellectual Property Forum 22.

Bollard, Alan and Harper, David Research and Development in New Zealand: A Public Policy Framework (NZIER NZ Institute of Economic Research/ Research Monograph 39, Wellington, 1987).

Bollard, Alan and Thompson, Mary Anne (eds) Trans-Tasman Trade and Investment: the effects of CER (New Zealand Institute of Economic Research and Victoria University Press for the Institute of Policy Studies, 1987).

Brinkhof, Jan "The Revocation of European Patents" (1996) 27 International Review of Intellectual Property and Competition Law, 225.

Brown, Andrew and Grant, Anthony The Law of Intellectual Property in New Zealand (Butterworth, Wellington, 1989).

Bucknell, Duncan Geoffrey; Beattie, Kate; Goatcher, Philip Andrew; Rofe, Helen M J Australian Patent Law (LexisNexis Butterworth, Chatswood, 2004).

Caenegem, William van Intellectual Property Law and Innovation (Cambridge University Press, New York, 2007).

Calhoun, Doug "Commodity hedging, trusts and broomstick putting: What is an invention?" (2009) 5 New Zealand Intellectual Property Journal 545.

Calhoun, Doug "International Developments: Patents and Biotechnology" Appendix B "Comments on WIPO/UPOV Paper CAJ/XXIV/4.

Carson, John M and Blonigan, William J "USA: Patents - Re-Examination" (2009) 31 EIPR N15.

Cohen, Julie E "Reverse Engineering and the Rise of Electronic Vigilantism: Intellectual Property Implications of 'Lock-Out' Programs" (1995) 68 Southern California Law Review 1091. 
Cornish, William Intellectual Property: Patents, Copyright, trade marks and allied rights (3 ed, Sweet \& Maxwell, London, 1996).

Cornish, William Intellectual Property: Omnipresent, Distracting, Irrelevant? (Oxford University Press, New York, 2004).

Dent, Chris "Decision-Making and Quality in Patents: An Exploration" (2006) 28 EIPR 381.

Dutfield, Graham and Suthersanen, Uma Global Intellectual Property Law (Edward Elgar, Cheltenham, 2008).

Eisenberg, Rebecca S "Patents and the Progress of Science: Exclusive Rights and Experimental Use" (1989) 56 University of Chicago Law Review 1017.

Farrell, J and Merges, Robert "Incentives to Challenge and Defend Patents: Why Litigation Won't Reliably Fix Patent Office Errors and Why Administrative Patent Review Might Help" (2004) 19 Berkeley Technical Law Journal, 943.

Finch, Ian (ed) James \& Wells Intellectual Property Law in New Zealand (Thomson Brookers, Wellington, 2007).

Fisher, Matthew Fundamentals of Patent Law Interpretation and Scope of Protection (Hart Publishing, Portland, 2007).

Frankel, Susy “A Patentable Invention: Will Current Proposed Law Reform Clarify Patentable Subject Matter?” (2005) 11 New Zealand Business Law Quarterly 350.

Frankel, Susy and Smith, Tim Essays on Intellectual Property Law and Policy (Victoria University Law Review, Wellington, 2001).

Frankel, Susy and McLay, Geoff Intellectual Property in New Zealand (LexisNexis Butterworths, Wellington, 2002).

Frankel, Susy "Lord Cooke and Patents: The Scope of 'Invention"” (2008) 39 VUWLR 73.

Mandich, Giulio "Venetian Patents (1450-1550)" (1948) 30 Journal of the Patent Office Society, 3.

Markus, Keith E and McDaniel, Christine "Impacts of the Japanese patent system on productivity growth" (1999) 11 Japan \& World Econ 557.

Graham, Stuart and Harhoff, Dietmar "Can Post-Grant Reviews Improve Patent System Design? A Twin Study of US and European Patents" (2006) GESY Discussion Paper 38.

Graham, Stuart; Hall, Bronwyn; Haroff, Dietmar and Mowery, David "Postissue Patent 'Quality Control': A comparative study of US patent reexamination and European patent opposition" (2002) NBER Working Paper Series No 8807.

Gollin, Michael A Driving Innovation: Intellectual Property Strategies for a Dynamic World (Cambridge University Press, New York, 2008).

Hansen, Hugh C Intellectual Property Law and Policy (Hart Publishing, Oxford, 2008).

Harhoff, Dietmar "The Demand for Patents and the Evolution of Patent Quality" paper presented to Advancing Knowledge and the Knowledge Economy Conference, National Academy of Sciences, 11 January 2005. 
Harhoff, Dietmar and Reitzig, Markus "Determinant of opposition against EPO patent grants - the case of biotechnology and pharmaceuticals" (2004) 22 International Journal of Industrial Organization 443.

Hirshleifer, Jack "The Private and Social Value of Information and the Reward to Inventive Activity" (1971) 61 American Economic Review 561.

Jaffe, Adam B and Lerner, Josh Innovation and Its Discontents: How our broken patent system is endangering innovations and progress, and what to do about (Princeton University Press, Princeton and Oxford, 2004).

Janis, Mark D "Rethinking Reexamination: Towards a Viable Administrative Revocation System for U.S. Patent Law" (1997) 11 Harvard Journal of Law and Technology 1.

Jensen, Paul; Palangkaraya, Alfons and Webster, Elisabeth "Patent Application Outcomes across Trilateral Patent Offices" (2005) Melbourne Institute Working Paper Series No.5/05.

Jensen, Paul $\mathrm{H}$ and Webster, Elizabeth "Achieving the Optimal Power of Patents Rights" (2004) Intellectual Property Research Institute of Australia Working Paper 15/04.

Kaiser, Jürgen "Up close - Finding an alternative to the European Opposition procedure" (2005) 176 Patent World 22.

Kesan, Jay P and Gallo, Andres A "Why "Bad" Patents survive in the market and how should we change? - The private and social cost of patents" (2006) 55 Emory Law Journal 62.

Kief, F Scott "The Case for Registering Patents and the Law and Economics of Present Patent-Obtaining Rules" (2003) 45 Boston College Law Review 55.

Landes, William M and Posner Richard A The Economic Structure of Intellectual Property Law The Belknap Press of Harvard University Press, Cambridge, Massachusetts and London, 2003).

Lemley, Mark "Rational Ignorance at the Patent Office" (2001) 95 Nordwestern University Law Review 1495.

Levin, Jonathan and Levin, Richard "Patent Oppositions" (2002) SIEPR Discussion Paper No. 01-29.

Machlup, Fritz An Economic Review of the Patent System - Study of the Subcommittee on Patents, Trademarks, and Copyrights of the Committee on the Judiciary (United States Government Printing Office, 1958).

Mandeville, Thomas D, Lamberton, Donald M and Bishop, E J Economic Effects of the Australian Patent System (Australian Government Publishing Service for Patents, Trade Marks and Designs Office, Canberra, 1982).

Markus, Keith E and McDaniel, Christine „Impacts of the Japanese patent system on productivity growth" (1999) 11 Japan \& World Econ 557.

Markus, Keith E. and Reichmann, Jerome H. International Public Goods and Transfer of Technology under a Globalized Intellectual Property Regime (Cambridge University Press, New York, 2005). 
Matsuura, Jeffrey H Jefferson vs the Patent Troll: A Populist Vision of Intellectual Property Rights (University of Virginia Press, Charlottesville \& London, 2008).

McGee, John S "Patent Exploitation: Some Economic and Legal Problems" (1966) 9 JL\&Econ 135.

McKeough Jill, Steward Andrew and Griffith, Philip Intellectual Property in Australia (3rd ed, LexisNexis Butterworth, Chatswood, 2004).

Merges, Robert P "As Many as Six Impossible Patents before Breakfast: Property Rights for Business Concepts and Patent System Reform" (1999) 14 Berkeley Technology Law Journal 577.

Merges, Robert P (ed) Economics of Intellectual Property Law Volume 1 (Edward Elgar Publishing, Cheltenham, 2007).

Merrill, Stephen A.; Levin, Richard C. and Myers Mark B. (eds) A Patent System for the 21th Century (National Academy Press, Washington D.C., 2004).

Merill, Stephen A "Improving Patent Quality: Connecting Economic Research and Policy" in Patents, Innovations and Economic Performance (OECD Conference Proceedings, Paris, 2004).

Nard, Craig Allen and Wagner, R Polk Patent Law (Foundation Press, New York, 2008).

Organization for Economic Cooperation \& Development Reviews of Innovation Policy NEW ZEALAND (OECDPublishing, Paris, 2007).

Pascarl, Ian "The Implications of the Changes Effected by the Patents Amendment Act 2001 for Successful Patenting of Inventions and Innovations" Australasian Biotechnology, Vol. 12 No. 2, 2002, 37.

Phillips, Jeremy (ed) Patents in Perspective (ESC Publishing Limited, Oxford, 1985).

Rosenberg, Peter D Patent Law Fundamentals (loose-leaf, 2ed, Clark Boardman Co., New York, 1980) Vol 1, para 1.02. (last updated 6/2000).

Rotstein, Fiona and Dent, Chris „Third Party Patent Challenges in Europe, the United States and Australia: A Comparative Analysis" (2009) University of Melbourne Legal Studies Research Paper No. 428.

Scherer, Frederic M New perspectives on economic growth and technological innovation (Brookings Institution Press, Washington, 1999).

Scherer, Frederic M and Ross, David Industrial Market Structure and Economic Performance (3rd ed, Houghton Mifflin, Boston, 1990)

Siebeck, Wolfgang E (ed) Strengthening Protection of Intellectual Property Law in Developing Countries: A Survey of the Literature (The World Bank, Washington DC, 1990).

Shi, Qin "Reexamination, Opposition, or Litigation? Legislative Efforts to Create a Post-Grant Patent Quality Control System", (2003) 31 AIPLA Quarterly Journal 433.

Thomas, John R „The Responsibility of the Rule-Maker: Comparative Approaches to Patent Administration Reform" (2002) 17 Berkeley Technology Law Journal 727. 
Walterscheid, Edward C "The Winged Gudgeon - An early Patent Controversy" (1997) 79 Journal of the Patent and Trademark Office Society 533.

White, T.A. Blanco Patents for Inventions and the Protection of Industrial Designs (5ed, Stevens \& Son, London, 1983).

Vaver, David (ed) Intellectual Property Rights - Critical Concepts in Law Volume III (Routledge, London and New York, 2006).

\section{Official documents}

Advisory Council on Industrial Property "Review of Enforcement of Industrial Property Rights" (1999).

Bureau of Industry Economics The Economics of Patents (AGPS, Canberra, 1994).

Commission on Health Research for Development Health Research Essential Link to Equity in Development (Oxford University Press, Oxford et all, 1990).

Commission to Inquire into and Report upon the Law of Patents, Design and Trade-Marks in "Report of the Commission" (Government Printer, Wellington, 1950).

Competition Policy and Business Law Division Review of Industrial Property Rights Patents, Trade Marks and Design: Possible Options for Reform (Ministry of Commerce, Wellington, 1990) Vol 1 and 2.

First Reading of the Patents Bill 2008 Hansard (5 May 2009) 654 NZPD 2883.

Her Majesty's Stationery Office The British Patent System: Report of the Committee to Examine the Patent System and Patent Law (the Banks Report) (London, 1970).

Industrial Property Advisory Committee Patents, Innovation and Competition in Australia (IPAC, Canberra, 1984).

Intellectual Property Office of New Zealand "Report of the Commissioner of Patents, Trade Marks and Designs to the Minister of Commerce for the year ended 30 June 2000" (IPONZ, Lower Hutt, 2001).

Intellectual Property Office of New Zealand „Report of the Commissioner of Patents, Trade Marks and Designs to the Minister of Commerce for the years ended 30 June 2008" (IPONZ, Wellington, 2008).

Intellectual Property Office of New Zealand "Report of the Commissioner of Patents, Trade Marks and Designs to the Minister of Commerce for the year ended 30 June 2009" (IPONZ, Wellington, 2010).

IPAC Report The Patent Monopoly Term and Extensions Thereof (Industrial Property Advisory Committee, Wellington, 1985).

IPAC Report The Adequacy of Definition and Disclosure in Patent Specifications Relating to Micro-Organism Inventions (Industrial Property Advisory Committee, Wellington, 1987).

Intellectual Property and Competition Review Committee Review of Intellectual Property Legislation under the Competition Principles Agreement (Commonwealth of Australia, 2000). 
Judiciary of England and Wales Civil Litigation Cost Review: Preliminary Report Vol. 2 (2009, London).

Ministry of Commerce Maori and the Patenting of Lifeform Inventions An Information Paper produced by the patenting Lifeforms Focus Group for the Ministry of Commerce (Ministry of Commerce, Wellington, 1999).

Ministry of Commerce Reform to the Patents Act 1953: Proposed Recommendations (Wellington, 1992).

Ministry of Economic Development Draft for Consultation Patents Bill 2004 (Wellington, 2004).

Ministry of Economic Development Review of the Patents Act 1953: Boundaries to Patentability (Wellington, 2002).

Ministry of Economic Development Submissions on Exposure Draft of Patents Bill (Wellington, 2005).

New Zealand Law Commission Intellectual Property: The Context for Reform (NZLC R13, Wellington, 1990).

Organization for Economic Cooperation \& Development Reviews of Innovation Policy NEW ZEALAND (OECDPublishing, Paris, 2007).

Patents Bill 235-1 (2008), available under www.http://www.legislation.govt.nz (last accessed 8 November 2009).

Probine, Mervyn CB Report on a Review of the Patent Office and the Administration of Intellectual Property Law (New Zealand Dept of Justice, Wellington, 1987).

United States Patent and Trademark Office Manual of Patent Examining Procedure (8th ed, 7th rev, Thomson/West, Washington, 2008).

USPTO "Mark Twain Granted His First Patent on December 19, 1871 Famous author and humorist was also an inventor" (18 December 2001) Press Release.

World Bank Doing Business Report (Palgrave Macmillan, 2009).

World Trade Organisation WT/TPR/S/216. 